4 nordon 



\section{Unintentional formation and emission of the persistent organic pollutants HCB and PCBs in the Nordic countries}

Documentation of existing information regarding sources and emissions to air, water and soil, with focus on reporting obligations according to the Stockholm Convention, the UNECE POP protocol, and PRTR registers

Thomsen, M., Nielsen, O.-K. \& Illerup, J.B.

TemaNord 2009:518 
Unintentional formation and emission of the persistent organic pollutants HCB and PCBs in the Nordic countries

Documentation of existing information regarding sources and emissions to air, water and soil, with focus on reporting obligations according to the Stockholm Convention, the UNECE POP protocol, and PRTR registers

TemaNord 2009:518

(C) Nordic Council of Ministers, Copenhagen 2009

ISBN 978-92-893-1842-6

Print:

Cover:

Layout:

Cover photo:

Copies: 0

Printed on environmentally friendly paper

This publication can be ordered on www.norden.org/order. Other Nordic publications are available at www.norden.org/publications

Printed in Denmark

Nordic Council of Ministers

Store Strandstræde 18

DK-1255 Copenhagen K

Phone (+45) 33960200

Fax (+45) 33960202

www.norden.org

wWw.norden.org

\section{Nordic Council}

Store Strandstræde 18

DK-1255 Copenhagen K

Phone (+45) 33960400

Fax (+45) 33111870

\section{Nordic co-operation}

Nordic cooperation is one of the world's most extensive forms of regional collaboration, involving Denmark, Finland, Iceland, Norway, Sweden, and three autonomous areas: the Faroe Islands, Greenland, and Åland.

Nordic cooperation has firm traditions in politics, the economy, and culture. It plays an important roli in European and international collaboration, and aims at creating a strong Nordic community in a strong Europe.

Nordic cooperation seeks to safeguard Nordic and regional interests and principles in the global community. Common Nordic values help the region solidify its position as one of the world's most innovative and competitive. 


\section{Content}

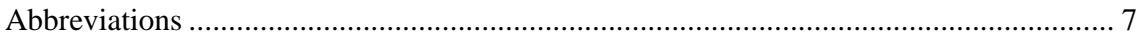

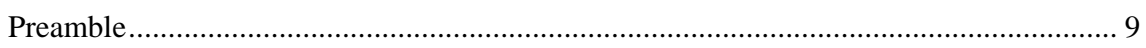

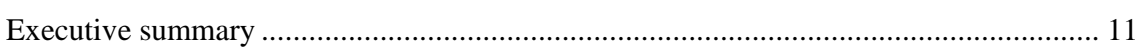

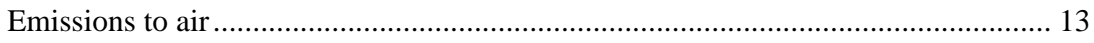

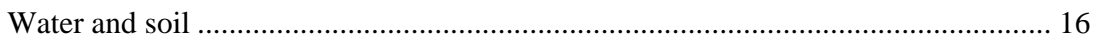

Overall trends in potential sources - air, soil and water ............................................. 17

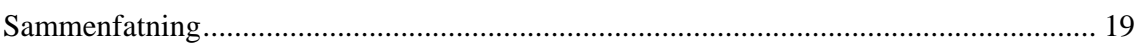

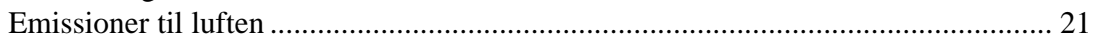

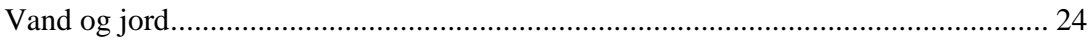

Overordnede tendenser i potentielle kilder - luft, vand og jord .................................. 26

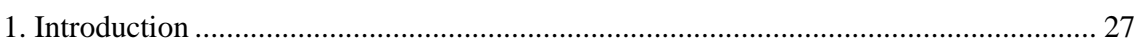

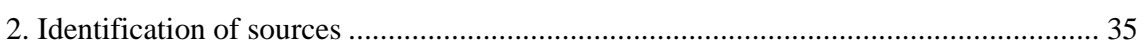

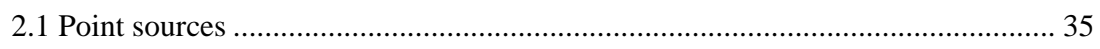

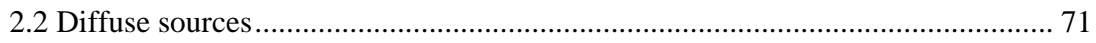

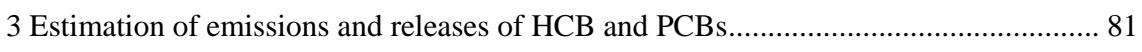

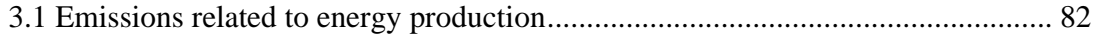

3.2 Emissions from the metal, mineral and chemical industries................................... 84

3.3 Emissions from waste and wastewater management .............................................. 86

3.4 Relative importance of emissions to air in the Nordic countries .......................... 90

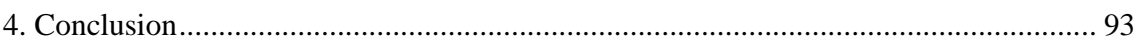

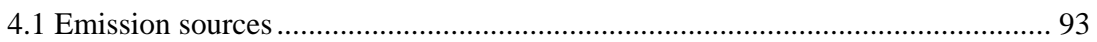

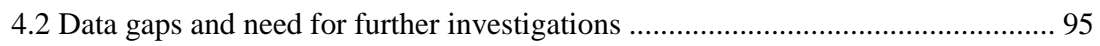

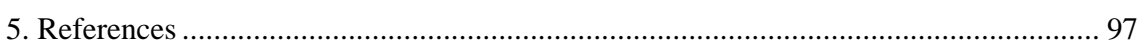

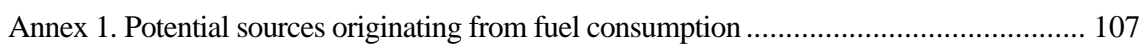

Annex 2. Potential sources within the metal and mineral industry sectors ..................... 115

Annex 3. Potential sources within the Chemical industry ........................................... 127

Annex 4. Activity data and emission factors related to waste and wastewater

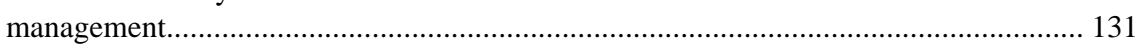

Annex 5. Chlorine in fuel types and waste fractions .................................................... 135

Annex 6. Cremation and Uncontrolled / Accidental burning....................................... 137

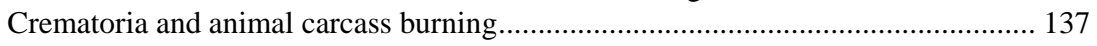

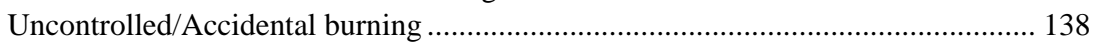





\section{Abbreviations}

\begin{tabular}{|c|c|}
\hline AFBC: & Atmospheric Fluidized Bed Combustion \\
\hline APCD: & Air Pollution Control Devices \\
\hline ASR: & Auto Shredder Residues \\
\hline BAT: & Best Available Technique \\
\hline BEP: & Best Environmental Practice \\
\hline BIPRO: & Beratungsgesellschaft für Integrierte Problemlösungen \\
\hline BREF: & Best available techniques REFerence documents \\
\hline CAMI: & Chlor-Alkali Manufacturing industry \\
\hline CLMI: & Cement and Lime Manufacturing Industries \\
\hline CRF: & Common Reporting Format \\
\hline DRE: & Destruction and Removal Efficiency \\
\hline EAF: & Electric Arc Furnaces \\
\hline ELV: & End-of-Life Vehicle's \\
\hline E-PRTR: & European Pollutant Release and Transfer Register \\
\hline FMPI: & Ferrous Metals Processing Industry \\
\hline GMI: & Glass Manufacturing Industry \\
\hline HCB: & HexaChloroBenzene \\
\hline IIR: & Informative Inventory Report \\
\hline IPPC: & Integrated Pollution Prevention and Control \\
\hline IS: & Iron and Steel \\
\hline LCP: & Large Combustion Plants \\
\hline LRTAP: & Long-Range Transboundary Air Pollution \\
\hline LVOC: & Large Volume Organic Chemicals \\
\hline MOGR: & Mineral Oil and Gas Refineries \\
\hline MSW: & Municipal Solid Waste \\
\hline MSWI: & Municipal Solid Waste Incineration \\
\hline MTWR: & Management of Tailings and Waste-Rock in mining activities \\
\hline NFMI: & Non Ferrous Metals Industries \\
\hline NRF: & Nomenclature Reporting Format \\
\hline NIP: & National Implementation Plan \\
\hline OFC: & Organic Fine Chemicals \\
\hline PCB: & PolyChlorinated Biphenyls \\
\hline ¿PCB6: & PCB-28, PCB-52, PCB-101, PCB-138, PCB-153 and PCB-180 \\
\hline ¿PCB7: & PCB-28, PCB-52, РCB-101, PCB-118, РCB-138, РCB-153 and PCB-180 \\
\hline PCDD: & PolyChlorinated Dibenzo-p-Dioxin \\
\hline PCDF: & PolyChlorinated Dibenzofuran \\
\hline POP: & Persistent Organic Pollutant \\
\hline PPI: & Pulp and Paper Industries \\
\hline PRTR: & Pollutant Release and Transfer Register \\
\hline RDF: & Refused Derived Fuel \\
\hline SABI: & Slaughterhouses and Animal By-products Industries \\
\hline SIC: & Speciality Inorganic Chemicals \\
\hline SR: & Shredder Residues \\
\hline TI: & Textile Industry \\
\hline TSFI: & Techniques in the Smitheries and Foundries Industry \\
\hline UNECE: & United Nations Economic Commission for Europe \\
\hline UPOP: & Unintentional Persistent Organic Pollutant \\
\hline WI: & Waste Incineration \\
\hline WTI: & Waste Treatment Industry \\
\hline WWTP: & Waste Water Treatment Plant \\
\hline
\end{tabular}





\section{Preamble}

All Nordic countries are parties to the Stockholm Convention on Persistent Organic Pollutants (the Stockholm Convention) and the Persistent Organic Pollutants Protocol (the POP Protocol) under the UNECE Convention on Long-Range Transboundary Air Pollution (LRTAP). According to the Stockholm Convention, parties to the convention have to reduce, with the aim of eliminating, the unintentional formation and emission of hexachlorobenzene (HCB) and polychlorinated biphenyls (PCBs). Emissions of these substances to air, water and soil must be assessed and reported.

The overall goal of the project is to compile existing information on emissions from unintentional formation of HCB and PCBs to air, water and soil, which is relevant for the Nordic countries in order to be able to report on such emissions in accordance with the reporting obligations under the Stockholm Convention, the POP Protocol, the PRTR Protocol and the EU PRTR regulation.

It should be noted that there may exist further relevant information regarding national sources to HCB and PCBs that has not been available to the authors within the time available for the elaboration of this project, and which has therefore not been included in the present report.

The project is financed by the Nordic Council of Ministers and coordinated by the Nordic Chemicals Group. The work has been performed by the National Environmental Research Institute (NERI), Aarhus University, Denmark. The project has been overseen by a Steering Group consisting of members from the environmental administrations of the participating Nordic countries of Denmark, Finland, Norway and Sweden.

Steering group:

- Mona Westergaard, Chair, Danish Environmental Protection Agency

- Kristina Saarinen, Finnish Environment Institute

- Christel Benestad, Norwegian Pollution Control Authority

- Niklas Johansson, Swedish Environmental Protection Agency

- Marianne Thomsen, project leader from NERI

The content of this report does not necessarily reflect the opinion of the Nordic countries or the Nordic Council of Ministers. 



\section{Executive summary}

The background of this project was the need for an overview of existing knowledge regarding sources of unintentional emissions of HCB and PCBs, relevant for the Nordic countries, with the purpose of enabling these countries to fulfil their reporting obligations under the Stockholm Convention on Persistent Organic Pollutants (POPs), the Persistent Organic Pollutants Protocol (the POP Protocol) under the UNECE LRTAP Convention, and finally the European Pollutant Release and Transfer Register (E-PRTR) according to regulation (Regulation (EC) No 166/2006), which implements the UNECE PRTR Protocol. These international agreements require reporting of unintentional emissions/releases of dioxin, HCB and PCBs to air, water and soil. However, until now actual reporting on unintentional emissions has mainly taken place for dioxin to air, and countries have not been able to report on unintentional emissions/releases of HCB and PCBs to air, water and soil, due to the difficulties in assessing these emissions/releases.

The aim of the project has been to improve the basis for reporting on the mentioned emissions/releases. It has been done by studying and assessing the existing knowledge regarding sources to unintentional formation and emission/release of HCB and PCB, including available information on source-specific activity data and emission factors. The project takes into account the latest research in the area and also identifies areas where there are gaps in knowledge. Focus has been on the review of existing knowledge on the potential sources rather than on delivering an inventory of emissions.

A general problem has been the lack of available data and emission factors that are directly applicable to the conditions in the Nordic countries. Some knowledge exists regarding unintentional emissions of HCB and PCBs to air in general, but there are considerable uncertainties and widespread lack of knowledge in relation to emissions from sources prevailing in the Nordic countries. This is even more pronounced in relation to emissions to water and soil, where knowledge is very limited. It has therefore not been possible in a meaningful way to assess any such potential releases to water and soil.

The study has pointed to a number of likely sources in the Nordic countries and possible emission magnitudes, and has thereby brought the counries a step closer to being able to report on emissions. However, it has also revealed that with the knowledge available ultimo 2007, a complete assessment of unintentional emissions of HCB and PCB is not possible.

The study shows that the relative importance of sources varies between the countries. No attempt has been made to compare emissions 
between countries; focus has been on identifying the most relevant sources for each country.

For the purpose of identifying sources, activities listed in the E-PRTR Regulation and the Source Categories listed in Annex C of the Stockholm Convention were used. A division into point sources and diffuse sources according to the approach presented by BiPRO (Beratungsgesellschaft für integrierte Problemlösungen) and the E-PRTR Regulation was adopted.

The PRTR activities that represent point sources have been grouped into 9 activity sectors:

- 1. Energy

- 2. Production and processing of metals (metal industry)

- 3. Mineral industry

- 4. Chemical industry

- 5. Waste and waste water management

- 6. Paper and wood production and processing

- 7. Intensive livestock production and aquaculture

- 8. Animal and vegetable products from the food and beverage sector

- 9. Other activities

In addition to the point sources listed above, diffuse sources, such as mobile sources (especially road transport), agriculture, diffuse stationary combustion/residential combustion including domestic heating as well as shipping, have been included.

It has not been possible within the scope of this study to conduct an indepth quality assurance and assessment of data sources at national or plant-specific process level.

Since focus is on the review of existing knowledge on the potential sources of unintentional formation and emission of HCB and PCBs rather than delivering an inventory, European level datasets comprising potential sources were preferred, since they represent national activity data. However, where national activity data have already been reported as part of the obligations under the UNECE Convention, these data have been used. This information has, where possible, been supplemented with national data and expert knowledge.

Potential sources of unintentional formation and emission of HCB and PCBs may be verified by information and data for sources related to activities at the national level. In cases where country-specific data on processes or activities as well as relevant emission factors have been available, indicative emission levels have been estimated. However, as neither uncertainty analysis nor in-depth quality assessment of the sources has been performed, and the data available are themselves subject to uncertainly, the results of calculations presented must be seen as solely indicative. 


\section{Emissions to air}

General aspects regarding available information on unintentional sources of emissions to air

Emissions to air are potentially formed unintentionally during e.g. combustion and other thermal processes within energy production, industrial processes or waste management processes. Furthermore, emissions may stem from diffuse sources such as road transport and residential combustion.

Due to the multitude of industrial production processes and specialized industries, there may be sources to PCB and HCB emission that have so far not been identified. Furthermore, data on production processes, for example within the chemical industry, are plant specific or scarce and difficult to obtain (SPIN database, and PRODCOM, 2007); therefore, the list of potential sources identified may be incomplete.

Potentially contaminated building materials and associated near-field exposure impacting on indoor air quality and human health have not been addressed in any detail.

Available information on fires at landfill sites and other accidental fires is incomplete, and therefore only partly allowed for an estimation of HCB or PCBs emissions from these sources (Annex 6). This source category may potentially be of importance for the total emission of HCB and PCBs, depending on the chlorine and organic matter content of the material deposited at the landfills in question. Emissions from crematoria were included for PCB, but are indicated to be of minor importance.

\section{Results}

\section{General}

Overall, the indicative air emission estimates suggest that combustion processes may be a main source of unintentional emission of HCB and PCBs. Regarding HCB, it seems that emissions from residential combustion of wood, a diffuse source, and combustion of waste, especially hazardous waste, are more important than combustion processes within the industry and point source within the energy sector. The picture is more differentiated regarding PCB emissions, but energy production from coal, mobile sources (road transport) and petroleum refineries seem to be general main sources.

Denmark

HCB: Residential combustion may represent one of the main sources of unintentional emissions of HCB. Combustion of waste, which in Denmark is always combined with energy production, may be another. However, a recent study on trends in dioxin emissions from combustion of 
waste indicates that this may no longer be the case. Combustion of hazardous waste and the chemical industry are also likely sources. Road transport, seem to be of little importance. Metal and mineral industries, being very small in Denmark, seem to be insignificant sources.

PCBs: Energy production based on combustion of coal seems to be the main source to unintentional emission of PCB, but road transport may also be of importance. Petroleum refineries, the mineral industry, waste treatment at shredder plants and energy production from waste may also be sources of some significance, while residential combustion and energy production of wood are likely to be minor sources.

Finland

HCB: The study points to combustion of hazardous waste, residential combustion of wood and the chemicals industry as being the main sources. However, in a recent national study in Finland, the chemical industry was estimated to contribute with up to $81 \%$ of the total emissions in 2004 (Saarinen et al., 2007). This is not consistent with the results of this study, which underlines the uncertainties involved. The Finnish estimation is likely to be more correct. The metal industry and energy production based on combustion of wood are indicated to be sources of some importance. Energy production of waste, combustion of municipal waste and road transport are suggested to be of minor importance.

PCBs: Energy production based on combustion of coal and combustion of waste seem to constitute the main sources of PCB. Road transport, energy production based on combustion of wood, metal industry and petroleum refineries are indicated to be sources of some importance. Residential combustion, the mineral industry and energy production from municipal waste seems to represent sources of lesser importance.

\section{Norway}

HCB: Emissions from residential combustion of wood and combustion of hazardous waste seem to be the main sources in Norway. The metal industry is indicated to be a source of some importance. Energy production from waste, combustion of municipal waste and road transport are indicated to be sources of lesser importance.

PCBs: Road transport and petroleum refineries seem to be the main sources to PCB emissions. The mineral industry, combustion of hazardous waste and the metal industry are indicated to sources of some importance. Residential combustion and energy production seem to represent minor sources.

\section{Sweden}

HCB: Residential combustion of wood and combustion of hazardous waste seem to comprise the main sources of emission of HCB in Sweden. Other sources that may be important are the metal industry, combustion 
of municipal waste and energy production from waste. Energy production from wood and road transport, seem to be lesser sources.

PCBs: Road transport and petroleum refineries seem to be the main sources to PCB emissions. Emissions from the metal industry, energy production of wood and coal, combustion of hazardous waste and the mineral industry may also be of importance. Residential combustion of wood, energy production from waste and combustion of municipal waste are indicated to be source of lesser importance in Sweden.

These findings are summarized in the tables below:

HCB emissions to air: Probable sources of importance

\begin{tabular}{|c|c|c|c|}
\hline Country & Main source & Medium source & Lesser source \\
\hline Denmark & $\begin{array}{l}\text { Residential combustion } \\
\text { (wood) } \\
\text { Energy production (waste)* }\end{array}$ & $\begin{array}{l}\text { Energy production (combus- } \\
\text { tion of hazardous waste) } \\
\text { Chemical industry }\end{array}$ & Mobile sources (road transport) \\
\hline Finland & $\begin{array}{l}\text { Combustion of hazardous } \\
\text { waste** } \\
\text { Residential combustion } \\
\text { (wood) } \\
\text { Chemical industry }\end{array}$ & $\begin{array}{l}\text { Metal industry } \\
\text { Energy production (wood) }\end{array}$ & $\begin{array}{l}\text { Energy production (waste) } \\
\text { Combustion of municipal waste } \\
\text { Mobile sources (road transport) }\end{array}$ \\
\hline Norway & $\begin{array}{l}\text { Residential combustion } \\
\text { (wood) } \\
\text { Combustion of hazardous } \\
\text { waste }\end{array}$ & Metal industry & $\begin{array}{l}\text { Energy production (waste) } \\
\text { Combustion of municipal waste } \\
\text { Mobile sources (road transport) }\end{array}$ \\
\hline Sweden & $\begin{array}{l}\text { Residential combustion } \\
\text { (wood) } \\
\text { Combustion of hazardous } \\
\text { waste }\end{array}$ & $\begin{array}{l}\text { Metal industry } \\
\text { Combustion of municipal } \\
\text { waste } \\
\text { Energy production (waste) }\end{array}$ & $\begin{array}{l}\text { Energy production (wood) } \\
\text { Mobile sources (road transport) }\end{array}$ \\
\hline
\end{tabular}

*Recent studies on dioxin indicate otherwise, see ref lab (2007).

${ }^{\star *}$ The data on emissions from the sources are very uncertain, see also section 3.3.1

PCB emissions to air: Probable sources of importance

\begin{tabular}{llll}
\hline Country & Main source & Medium source & Lesser source \\
\hline Denmark & $\begin{array}{l}\text { Energy production (coal) } \\
\text { Mobile sources (road } \\
\text { transport) }\end{array}$ & $\begin{array}{l}\text { Petroleum refineries } \\
\text { Mineral industry } \\
\text { Waste treatment (shredder) } \\
\text { Energy production (waste) }\end{array}$ & $\begin{array}{l}\text { Residential combustion (wood) } \\
\text { Energy production (wood) }\end{array}$ \\
\cline { 3 - 4 } Finland & Energy production (coal) & Mobile sources (road trans- & Residential combustion (wood) \\
& Combustion of hazardous & port) & Mineral industry \\
& waste & Energy production (wood) & Energy production (municipal \\
& & Metal industry & waste) \\
& & Petroleum refineries & \\
Norway & Mobile sources (road & Mineral industry & Residential combustion (wood) \\
& transport) & Combustion of hazardous & Energy production (coal) \\
& Petroleum refineries & waste & Energy production (waste) \\
& & Metal industry & Energy production (wood) \\
& & Metal industry & Residential combustion (wood) \\
Sweden & Eobile sources (road & Energy production (wood) & Energy production (waste) \\
& transport) & Combustion of municipal waste \\
& Petroleum refineries & Combustion of hazardous & \\
& & waste & \\
& & Mineral industry & \\
& & &
\end{tabular}


Gaps in knowledge

A main gap is the lack of emissions factors for unintentional emissions to air of HCB and PCB for the types of plants operating in the Nordic Countries.

\section{Water and soil}

General aspects regarding available information on unintentional sources of release to water and soil

Available data for releases to water and soil are more scattered and incomplete than the data for air emissions, and until recently there was a general lack of harmonized reporting systems and statistics. It has not been possible to conduct an in-depth assessment of the potential sources of releases to water and soil within the framework of this study. This also includes secondary sources, for example redistribution form contaminated sites. It has therefore, as mentioned earlier, not been possible to meaningfully undertake an assessment of the magnitude of such releases.

The available data and information on release of HCB and PCBs to water and soil suggest that potential sources comprise by-products and waste such as solid and liquid residues, solid waste, oils and wastewater. Especially industrial sources and waste management processes seem to be of importance, depending on final disposal and recovery. Examples include industrial wastewater, waste incineration and waste from energy production. Since the amount of waste produced is increasing, this may be an important source. However, activities centring on avoiding problematic content in waste and the reuse and recycling of waste are on the rise in the Nordic countries, and therefore this need not be the case these countries.

On the basis of the available information, the most important sources seem to be:

Solid residues and waste

Releases from solid residue, e.g. fly ash from combustion processes deposited at landfill sites, especially depend on whether post-combustion of residues has taken place to further increase the destruction efficiency, and on the potential source intensity of the solid residues. Where the residues are not deposited as landfill, their future potential release will depend on the final reuse category, for example use of fly ash in cement or asphalt production.

Accidental emissions from release of percolates from landfill and sludge used as fertiliser may be other potential sources. Sludge as a source will depend on the degree to which influent organic matter in in- 
dustrial wastewater contributes to the final sludge production. However, strict quality requirements apply to sludge in the Nordic countries.

Accidental leakage

Accidental leakage, or release, of e.g. percolates from old landfill sites or residue oils may result in release to soil and water, despite technological developments and measures to protect the underlying soil and groundwater.

Wastewater

Industrial wastewater from wet scrubbing processes may include problematic suspended solids to varying degree, depending on which pretreatment is undertaken prior to discharge to surface waters or to municipal sewer systems, where this is permitted. The cleaning efficiency of industrial wastewater and the organic load in wastewater that enters centralized wastewater treatment plants is not well known. However, based on available data from separate industrial wastewater effluents in Denmark, there seems to be no or little need for concern regarding HCB and PCBs in the effluent wastewater from industrial point sources.

\section{Overall trends in potential sources - air, soil and water}

Technology, practices, rules and regulations are improving, and this may influence the relative importance of different sources in the future, reducing the emissions and releases from known sources.

Relevant for all the Nordic countries are several EU regulations concerning waste and reuse of end-of-life vehicles as well as other products, e.g. electric and electronic products. These regulations may be drivers behind the trends for the emissions and release of HCB and PCBs to air, soil and water.

More and better data, inter alia on emission/release factors, would be needed to make an optimal assessment of the trends for future emissions and releases, but based on the available knowledge the following relatively new sources might increase in importance:

- landfill as a temporary deposit site for e.g. aerobic mineralization of sludge mixed with private garden waste for production of e.g. compost

- end-of-life tyres for use in industrial production processes, e.g. asphalt production

- co-combustion in cement kilns

- fugitive emissions and/or accidental leakage to underlying soil from deposited slag and other solid residues from combustion processes and incineration of hazardous waste 



\section{Sammenfatning}

Baggrunden for dette projekt har været behovet for en oversigt over den eksisterende viden vedrørende kilder til utilsigtede udledninger af HCB og PCB, som kan være relevante for de nordiske lande, med det formål at gøre landene i stand til at efterleve deres rapporteringsforpligtelser under den globale Stockholm konvention om persistente organiske forurenende stoffer, protokollen om persistente organiske forurenende stoffer (POPprotokollen) som hører under Konventionen om Langtrækkende Grænseoverskridende Luftforurening (CLRTAP) i regi af FN's økonomiske kommission for Europa (UNECE), og endelig det europæiske register over udledning og overførsel af forurenende stoffer (PRTR) ifølge forordning EF nr. 166/2006, som implementerer UNECE's PRTR protokol. Under disse internationale aftaler indgår der rapporteringsforpligtelser for utilsigtede emissioner/udslip af dioxin, HCB og PCBer til luft, vand og jord. Dog er der primært sket rapportering hvad angår utilsigtede emissioner af dioxin til luft, idet vidensgrundlaget ikke har tilladt en rapportering af utilsigtede udslip af HCB og PCB til luft til vand og jord, på grund af vanskelighederne ved at estimere disse emissioner/udslip.

Målet med projektet har været at forbedre basis for rapportering af de nævnet emissioner/udledninger. Det er blevet gjort ved at gennemgå og vurdere den eksisterende viden om kilder til utilsigtet dannelse om emission/udledning af HCB og PCB, herunder tilgængelig information om kilde-specifikke aktivitetsdata og emissionsfaktorer. Projektet tager hensyn til den nyeste viden og identificerer områder, hvor der er huller i vores viden. Der har været fokus på en gennemgang af eksisterende viden om potentielle kilder, fremfor på at forsøge at udarbejde en oversigt over estimerede emissioner.

Et generelt problem har været manglen på tilgængelige data, samt emissionsfaktorer der er direkte anvendelige i de nordiske lande. Der eksisterer en vis viden om utilsigtede emissioner af HCB og PCB til luft generelt, men der er betydelige usikkerheder og en udbredt mangel på viden om emissioner fra de faktiske kilder i de nordiske lande. Dette er endnu mere udtalt for emissioner til vand og jord, hvor viden er meget begrænset. Det har derfor ikke været muligt at vurdere omfanget af potentielle udslip til vand og jord.

Rapporten peger på et antal sandsynlige kilder til emissioner i de nordiske lande og deres mulige størrelsesorden, og landene er derfor kommet et skridt nærmere til at kunne rapportere deres emissioner. Med den viden der er tilgængelig ultimo 2007 vil det ikke være muligt at udarbejde en fuldstændig opgørelse af utilsigtede emissioner af HCB og PCB. 
Rapporten viser, at den relative betydning af kilderne varierer mellem landene. Det har ikke været forsøgt at sammenligne emissioner mellem landene, fokus har været på at identificere de mest relevante kilder for hvert land.

Med det formål at identificere kilder, er der anvendt de aktiviteter, som er opført i E-PRTR forordningen, samt de kildekategorier, der fremgår af Stockholmkonventionens bilag C. Der er anvendt en tilgang til opdeling i punktkilder og diffuse kilder, som er anvendt af BiPRO (Beratungsgesellschaft für integrierte Problemlösungen) og i E-PRTR forordningen.

De PRTR aktiviteter, som repræsenterer punktkilder er blevet opdelt i 9 aktivitetssektorer.

- 1. Energi

- 2. Produktion og forarbejdning af metaller (metalindustri)

- 3. Mineralindustri

- 4. Kemisk industri

- 5. Affald og spildevandsforvaltning

- 6. Papir- og træproduktion og processering

- 7. Intensiv dyreproduktion og aquakultur

- 8. Dyre- og vegetabilske produkter fra føde- og drikkevaresektoren

- 9. Andre aktiviteter

Udover de punktkilder, der er opført ovenfor, er der inkluderet diffuse kilder såsom mobile kilder (primært vejtrafik), landbrug, forbrændingsanlæg i husholdninger og skibsfart. Det har ikke været muligt inden for rammerne at dette studie at gennemføre en dybdegående kvalitetssikring af datakilder på nationalt niveau eller anlægsniveau.

Siden der er fokus på en gennemgang af eksisterende viden om de potentielle kilder til utilsigtet dannelse og emission af HCB og PCB, frem for at forsøge at udarbejde en oversigt over emissionerne, er det foretrukket at benytte materiale med data over potentielle kilder på europæisk niveau, siden det repræsenterer samlede nationale aktivitetsdata. Undtaget herfra er dog tilfælde, hvor nationale data er blevet rapporteret som led i forpligtelserne under UNECE, hvor disse er anvendt i stedet. Disse oplysninger er, hvor muligt, blevet suppleret med nationale data og ekspertviden.

Potentielle kilder til utilsigtet dannelse og emission af HCB og PCB kan til tider blive verificeret af information og data for kilder relateret til aktiviteter på nationalt niveau. I tilfælde hvor landespecifikke data om processer eller aktiviteter, såvel som relevante emissionsfaktorer, har været til rådighed, er der blevet foretaget en estimering af indikative emissionsniveauer. Det skal understreges, at de estimeringer, der er foretaget må anses alene som indikative, da hverken følsomhedsanalyser eller 
dybdegående kvalitetssikring af kilder er blevet foretaget, og data i sig selv er behæftet med usikkerhed.

\section{Emissioner til luften}

Generelle aspekter vedrørende tilgængelig information om utilsigtede kilder til emissioner til luften

Emissioner til luften kan dannes utilsigtet ved fx forbrænding og andre termiske processer indenfor energiproduktion, industriprocesser eller affaldshåndteringsprocesser. Emissioner kan også stamme fra diffuse kilder som vejtransport og energiproduktion i husholdninger - primært til boligopvarmning.

På grund af de mange forskellige industrielle produktionsprocesser og specialiserede industrier, kan der være kilder, som hidtil ikke er blevet identificeret. Desuden er data fra produktionsprocesser, for eksempel indenfor den kemiske industri, specifikke for det enkelte anlæg eller ganske få, og vanskelige at få adgang til (SPIN databasen og PRODCOM, 2007). Derfor kan listen over identificerede potentielle kilder være ukomplet.

Der er ikke set nærmere på potentielt forurenede byggematerialer og tilhørende forurening i nærområdet, som kan påvirke luftkvalitet og dermed indendørs luftkvalitet og menneskers sundhed.

Information om brande på lossepladser og andre utilsigtede brande er ukomplet, hvilket påvirker estimeringen af emissioner fra disse kilder, som angivet i bilag 6 . Kilderne fra denne kategori kan være af betydning for estimeringen af den totale emission af HCB og PCB, men det afhænger af indholdet af klorholdigt materiale og organisk materiale, som er deponeret på lossepladserne m.m. Emissioner fra krematorier er inkluderet hvad angår PCB, men vurderes at være af mindre betydning.

\section{Resultater}

Generelle

Overordnet set indikerer emissionsestimaterne, at forbrændingsprocesser kan være den relativt største kilde til utilsigtede emissioner af HCB og PCBer. Hvad angår HCB, ser det ud til, at emissioner fra forbrændingsanlæg i husholdninger baseret på biomasse, en diffus kilde, og forbrænding af affald, især farligt affald, er vigtigere end forbrændingsprocesser i industrien og energisektoren (store anlæg). Billedet er mere komplekst hvad angår PCB emissioner, men energiproduktion fra kul, mobile kilder (vejtransport) og raffinaderier ser ud til generelt at være de relativt største kilder. 
Danmark

HCB: Forbrændingsanlæg i private husholdninger ser ud til at være kilde til en af de relativt største andele af emissioner af HCB i Danmark. Forbrænding af affald, som i Danmark altid er kombineret med samproduktion af energi, kan udgøre en anden. Dog viser et nyligt studie om udviklingen i dioxinemissioner i Danmark fra affaldsforbrændingsanlæg, at det sandsynligvis ikke er tilfældet længere. Forbrænding af farligt affald og kemisk industri er også sandsynlige kilder. Vejtransport ser ud til at være af begrænset betydning, mens metal og mineral industrierne ser ud til at være ubetydelige kilder.

PCB: Energiproduktion baseret på forbrænding af kul ser ud til at være kilde til den overvejende del af emissioner af PCB, men vejtrafik kan også være af betydning. Raffinaderier, mineral industrien, affaldsbehandling fra shredderanlæg og energiproduktion fra affald kan også ud til at være af betydning, hvorimod forbrændingsanlæg i private husholdninger og energiproduktion baseret på træ (store anlæg), ser ud til at være mindre kilder.

Finland

HCB: Studiet peger på forbrænding af farligt affald, forbrændingsanlæg i husholdninger (træ) og kemikalieindustrien som de tre relativt største kilder, med forbrænding af farligt affald som den største. Et nyligt nationalt studie estimerer i modstrid hermed, at den kemiske industri bidrager med op til $81 \%$ af de totale emissioner i 2004 (Saarinen et al., 2007). At de to studier ikke er konsistente understreger usikkerhederne på området, og det finske studie må antages at være mere korrekt. Metalindustrien og energiproduktion base på træ tyder også på at være kilder af nogen betydning. Energiproduktion fra affald, forbrænding af husholdningsaffald og vejtransport ser ud til at være af mindre betydning.

PCB: Energi produktion baseret på forbrænding af kul og forbrænding af affald ser ud til at være kilder til den overvejende del af PCB udledninger i Finland. Vejtransporten, energiproduktion baseret på forbrænding af træ, metalindustrien og raffinaderier ser også ud til at være af betydning. Forbrændingsanlæg i private husholdninger, mineral industrien og energiproduktion fra husholdningsaffald ser ud til at være af mindre betydning.

\section{Norge}

HCB: Emissioner fra forbrændingsanlæg i private husholdninger og forbrænding af farligt affald ser ud til være kilder til den overvejende del af emissioner i Norge. Metal industrien ser også ud til at være af beydning. Energiproduktion fra affald, forbrændingsanlæg i private husholdninger og vejtransport ser ud til at være kilder af mindre betydning.

PCB: Vejtransport og raffinaderier ser ud til at være kilder til den overvejende del af PCB emissionerne. Mineralindustrien, forbrænding af 
farligt affald og metalindustrien er sandsynligvis også kilder af en vis betydning. Energiproduktion i husholdninger samt energi produktion på store anlæg ses som mindre betydelige kilder.

\section{Sverige}

HCB: Forbrændingsanlæg i private husholdninger og forbrændingen af farligt affald ser ud til at udgøre kilderne til den overvejende del af emissioner af HCB i Sverige. Andre kilder, der kan være af betydning er metalindustrien, forbrænding af husholdningsaffald og energiproduktion baseret på affald. Energiproduktion fra træ og vejtransport ser ud til at være kilder af mindre betydning.

PCB: Vejtransport og raffinaderier ser ud til at være kilder til den overvejende del af PCB emissionerne i Sverige. Emissioner fra metalindustrien, energiproduktion på basis af træ og kul, forbrænding af farligt affald og mineralindustrien kan også være af betydning. Forbrændingsanlæg i private husholdninger, energiproduktion baseret på affald og forbrænding af husholdningsaffald er sandsynligvis kilder som er af mindre betydning i Sverige.

De væsentligste fund kan opsummeres i tabellerne nedenfor:

НСB emissioner til luften: Sandsynlige kilder af betydning

\begin{tabular}{|c|c|c|c|}
\hline Land & Relativt største kilde & Relativt mellemste kilde & Relativt mindste kilde \\
\hline Danmark & $\begin{array}{l}\text { Forbrændigsanlæg i } \\
\text { husholdninger (træ) } \\
\text { Enerigiproduktion (af- } \\
\text { fald)* }\end{array}$ & $\begin{array}{l}\text { Energiproduktion (farligt } \\
\text { affald) } \\
\text { Kemisk industri }\end{array}$ & $\begin{array}{l}\text { Mobile kilder (vejtrans- } \\
\text { port) }\end{array}$ \\
\hline Finland & $\begin{array}{l}\text { Forbrænding af farligt } \\
\text { affald** } \\
\text { Forbrændigsanlæg i } \\
\text { husholdninger (træ) } \\
\text { Kemisk industri }\end{array}$ & $\begin{array}{l}\text { Metalindustri } \\
\text { Energiproduktion (træ) }\end{array}$ & $\begin{array}{l}\text { Energiproduktion (affald) } \\
\text { Forbrænding af hushold- } \\
\text { ningsaffald } \\
\text { Mobile kilder (vejtrans- } \\
\text { port) }\end{array}$ \\
\hline Norge & $\begin{array}{l}\text { Forbrændigsanlæg i } \\
\text { husholdninger (træ) } \\
\text { Forbrænding af farligt } \\
\text { affald }\end{array}$ & Metal industri & $\begin{array}{l}\text { Energiproduktion (affald) } \\
\text { Forbrænding af hushold- } \\
\text { ningsaffald } \\
\text { Mobile kilder (vejtrans- } \\
\text { port) }\end{array}$ \\
\hline Sverige & $\begin{array}{l}\text { Forbrændigsanlæg i } \\
\text { husholdninger (træ) } \\
\text { Forbrænding af farligt } \\
\text { affald }\end{array}$ & $\begin{array}{l}\text { Metalindustri } \\
\text { Forbrænding af hushold- } \\
\text { ningsaffald } \\
\text { Energiproduktion (affald) }\end{array}$ & $\begin{array}{l}\text { Energiproduktion (træ } \\
\text { Mobile kilder (vejtrans- } \\
\text { port) }\end{array}$ \\
\hline
\end{tabular}

*Nylige studier af udviklingen i de utilsigtede emissioner af dioxin tyder på, at dette ikke længere er tilfældet, se ref lab (2007)

**Data forbundet med forøget usikkerhed, se afsnit 3.3.1 
PCB emissioner til luft. Sandsynlige kilder af betydning

\begin{tabular}{|c|c|c|c|}
\hline Land & Relativt største kilde & Relativt mellemste kilde & Relativt mindste kilde \\
\hline Danmark & $\begin{array}{l}\text { Energiproduktion (kul) } \\
\text { Mobile kilder (vejtrans- } \\
\text { port) }\end{array}$ & $\begin{array}{l}\text { Raffinaderier } \\
\text { Mineralindustri } \\
\text { Affaldsbehandling (shredder) } \\
\text { Energiproduktion (affald) }\end{array}$ & $\begin{array}{l}\text { Forbrændigsanlæg i } \\
\text { husholdninger (træ) } \\
\text { Energiproduktion (træ) }\end{array}$ \\
\hline Finland & $\begin{array}{l}\text { Energiproduktion (kul) } \\
\text { Forbrænding af farligt } \\
\text { affald }\end{array}$ & $\begin{array}{l}\text { Mobile kilder (vejtransport ) } \\
\text { Energiproduktion (træ) } \\
\text { Metalindustri } \\
\text { Raffinaderier }\end{array}$ & $\begin{array}{l}\text { Forbrændigsanlæg i } \\
\text { husholdninger } \\
\text { Mineralindustri } \\
\text { Energiproduktion (hus- } \\
\text { holdningsaffald) }\end{array}$ \\
\hline Norge & $\begin{array}{l}\text { Mobile kilder (vejtrans- } \\
\text { port) } \\
\text { Raffinaderier }\end{array}$ & $\begin{array}{l}\text { Mineralindustri } \\
\text { Forbrænding af farligt affald } \\
\text { Metalindustri }\end{array}$ & $\begin{array}{l}\text { Forbrændigsanlæg i } \\
\text { husholdninger (træ) } \\
\text { Energiproduktion (kul) } \\
\text { Energiproduktion (affald) } \\
\text { Energiproduktion (træ) }\end{array}$ \\
\hline Sverige & $\begin{array}{l}\text { Mobile kilder (vejtrans- } \\
\text { port) } \\
\text { Raffinaderier }\end{array}$ & $\begin{array}{l}\text { Metalindustri } \\
\text { Energiproduktion (træ) } \\
\text { Energiproduktion (kul) } \\
\text { Forbrænding af farligt affald } \\
\text { Mineralindustri }\end{array}$ & $\begin{array}{l}\text { Forbrændigsanlæg i } \\
\text { husholdninger (træ) } \\
\text { Energiproduktion (affald) } \\
\text { Forbrænding af hushold- } \\
\text { ningsaffald }\end{array}$ \\
\hline
\end{tabular}

Mangler i den eksisterende viden om utilsigtede emissioner af HCB og PCB til luft

Der er en væsentlig mangel på viden hvad angår emissionsfaktorer for utilsigtede udledninger af HCB og PCB til luft på den type af anlæg, som opererer i de nordiske lande i dag.

\section{Vand og jord}

Generelle aspekter vedrørende tilgæengelig information om utilsigtede kilder til udledninger til vand og jord

Tilgængelige data for udledninger til vand og jord er mere spredte og ukomplette end data for emissioner til luften, og indtil for nylig var der en generel mangel på harmoniserede rapporteringssystemer og statistikker. Der har ikke været muligt at gennemføre en dybdegående undersøgelse af de potentielle kilder til vand og jord inden for rammerne af dette studie. Dette gælder også sekundære kilder, for eksempel udledninger fra forurenede områder. Det har derfor som nævnt ikke været muligt på en meningsfuld måde at gennemføre en vurdering af størrelsesordenen af sådanne udledninger.

De tilgængelige data og den tilgængelige information om udledninger af HCB og PCB til vand og jord tyder på, at potentielle kilder kan være biprodukter og affald, såsom faste og flydende restprodukter, fast affald, olie og spildevand. Især industrielle kilder og affaldsbehandlingsprocesser ser ud til at være relevante, afhængig af en endelig deponering og genanvendelse. Eksempler inkluderer industrielt spildevand og restpro- 
dukter fra affaldsforbrænding og energiproduktion. Siden mængden af produceret affald generelt er for opadgående, kan dette være en potentielt betydningsfuld kilde. På den anden side, da der er en stigende indsats i de nordiske lande for at undgå problematisk indhold i affald, og mere fokus på genanvendelse og genbrug af affald, behøver det ikke at være tilfældet.

På basis at den tilgængelige information, ser de væsentligste kilder ud til at være:

Faste restprodukter og affald

Udledninger fra faste restprodukter, fx flyveaske fra forbrændingsprocesser deponeret på lossepladser, afhænger især af, hvorvidt efterbrænding af restprodukter har fundet sted for at forbedre destruktionseffektiviteten, og på den potentielle kildeintensitet af det faste restprodukt. Hvor restprodukterne ikke er deponeret på losseplads, vil deres potentielle fremtidige udledningspotentiale afhænge af den endelige anvendelseskategori, for eksempel brug af flyveaske i cement eller asfaltproduktion.

Udledninger som følge af uheld med perkolat fra lossepladser og slam brugt som gødning kan være andre potentielle kilder. Potentialet for slam som kilde vil afhænge af den grad, hvormed organisk materiale tilført med industrispildevand bidrager til den samlede slamproduktion. Der er dog strenge kvalitetskrav til slam i de nordiske lande.

Lækager som følge af uheld

Lækager eller udledninger som skyldes uheld med fx perkolat fra gamle lossepladser eller restolier kan medføre udledninger til jord og vand, til trods for teknologiske udviklinger og tiltag for at beskytte jord og grundvand.

\section{Spildevand}

Industrielt spildevand fra vådvaskningsprocesser kan indeholde problematiske stoffer i varierende grad. Det afhænger af, hvilken forudgående behandling, der er foretaget inden spildevandet udledes til overfladevandet eller - hvor dette er tilladt - til kommunale rensningsanlæg. Renseeffektiviteten for industrispildevand, og det organiske indhold i spildevand, der kommer til centrale spildevandsanlæg, er ikke velkendt. Dog tyder tilgængelige data fra Danmark på, at der ikke er grund til bekymring vedrørende HCB og PCB i det spildevand, der udledes fra industrielle punktkilder. 


\section{Overordnede tendenser i potentielle kilder - luft, vand og jord}

Teknologi, praksis, regler og reguleringer forbedres stadig, og dette kan have indflydelse på den relative betydning af forskellige kilder til utilsigtede udledninger af HCB og PCB i fremtiden.

Adskillige EU forordninger vedrørende affald og genbrug af udtjente køretøjer såvel som andre produkter, fx elektriske og elektroniske produkter, er relevante for alle de nordiske lande. Disse forordninger kan være med til at drive udviklingen i forbindelse med emissioner og udledninger.

Flere og bedre data, blandt andet om emissions- og udledningsfaktorer, er nødvendige for at foretage en optimal opgørelse af tendenserne for fremtidige emissioner og udledninger, men baseret på den eksisterende viden, kan de følgende relativt nye kilder potentielt stige i vigtighed:

- lossepladser som midlertidigt deponi for fx aerob mineralisering af slam blandet med privat haveaffald for produktion af fx kompost

- udtjente dæk til brug i industrielle processer, fx asfaltproduktion

- sam-forbrænding i cementovne

- flygtige emissioner og/eller utilsigtet lækage til underliggende jord fra deponeret slagger og andre faste restprodukter fra forbrændingsprocesser og forbrænding af farligt affald. 


\section{Introduction}

This project, under the Nordic Council of Ministers, Nordic Chemicals Group, provides an overview of existing information regarding sources and unintentional emissions of hexachlorobenzene (HCB) and polychlorinated biphenyls (PCBs) to soil, water and air. Focus is on reporting obligations according to the Stockholm Convention, the UNECE POP Protocol and the PRTR registers under the UNECE PRTR Protocol and the EU PRTR regulation. This potentially contributes to attainment of the objectives of the Stockholm Convention and other POP-related EU and international regulation in the long run, and thereby to a better environment in the Nordic countries, the Arctic and globally.

These international agreements require reporting of unintentional emissions/releases of dioxin, HCB and PCBs to air, water and soil. However, until now actual reporting on unintentional emissions has mainly taken place for dioxin to air, and countries have not been able to report on unintentional emissions/releases of HCB and PCBs to air, water and soil, due to the difficulties in assessing these emissions/releases. A toolkit (guidelines) for unintentional formation and emission of dioxins/furans has been elaborated under the Stockholm Convention. However, no such toolkit has been prepared for HCB and PCBs, because of the limited knowledge of the unintentional formation and emission of these substances. This limitation in knowledge also applies to the Nordic countries.

No attempt has been made to compare emissions between countries; focus has been on identifying the most relevant sources for each country. Furthermore, any assessment of potential consequences for the environment or health of the indicative emissions/releases is outside the scope of this study.

PCBs cover a group of 209 different PCB congeners which can be divided into two groups according to their toxicological properties. One group, consisting of 12 congeners, shows toxicological properties similar to dioxins and is therefore termed 'dioxin-like PCBs' or 'co-planar PCB', with reference to their conformation. The general human exposure to dioxins and these dioxin-like PCBs in Europe is still close to the TDI (Tolerable Daily Intake) set by the EU (SCF, 2001). In fact, more than $10 \%$ of the Swedish population is estimated to overstep this TDI. The other PCBs, referred to as 'non dioxin-like PCBs' do not primarily interact by means of a similar mode of action as the dioxins. This does not mean that these PCBs lack toxicological properties. On the contrary, they have been shown to be able to generate a variety of other toxic effects. Both groups of PCB are usually found in the environment. PCB was formerly used widely in a number of industrial and commercial applications. 
It is estimated that more than 1 million tonnes of technical PCB mixtures have been produced worldwide since their first commercial use in the late 1920s.

Although the manufacture, processing and distribution of PCBs have been prohibited in almost all industrial countries since the late 1980s, their entry into the environment still occurs, especially due to improper disposal practices or leaks in electrical equipment and hydraulic systems still in use. A number of industrial and other high-temperature processes have been shown to generate PCBs via de novo synthesis.

Data on the occurrence of PCBs in the environment have been reported in many different ways: e.g. as PCB congener 153 only; as the sum of three PCB congeners (PCB 138, 153 and 180); as the sum of six PCB congeners (PCB 28, 52, 101, 138, 153, 180), often referred to as indicator PCB; or as the sum of seven (sum of six indicator PCB plus PCB congener 118). This lack of consistency hampers a comparison of occurrence data.

For the sake of simplicity, in the present investigation the term PCB has been used for all possible combinations. This of course introduces a certain amount of uncertainty to the analysis, but this uncertainty is regarded as considerably smaller than a number of other uncertainties present in this compilation.

PCBs, as a group, are chemically stable/inert, heat resistant and nonflammable, and have particularly useful dielectric properties. PCBs were utilized in a wide variety of open, nominally closed and closed systems. Open use included the addition of PCBs in plasticizers, carbonless copy paper, lubricating oils, inks, laminating and impregnating agents, paints, adhesives, waxes, additives to cement and plaster, casting agents, dedusting agents, sealing liquids, fire retardants, immersion oils and pesticide extenders (de Voogt and Brinkman, 1989). Nominally closed and closed usage applications included hydraulic and heat transfer fluids, small capacitors in cars and household electrical appliances, vacuum pumps, as well as transformers and large capacitors. Electrical companies were the largest users of PCBs worldwide. PCBs can enter the environment via a number of different pathways, e.g. direct emission from equipment still in use or in storage, emission from PCB-contaminated waste or from contaminated sites, disposal areas, etc. In the past products containing PCBs may have constituted a source for release from landfill to water and air (BiPRO, 2006; DEFRA, 2006). Today equipment containing PCBs is disposed of by chemical incineration (Directive 2000/76/EC).

Due to their very low biodegradability in the environment and their tendency to bioaccumulate, and biomagnify, PCBs belong to the so-called persistent organic pollutants (POPs). In spite of their low vapour pressure, and partly as a result of their hydrophobicity, PCBs volatilize from water surfaces. Many of the individual PCB compounds exhibit toxic 
properties. PCBs rarely cause acute toxic effects, but most of the effects observed are the result of repetitive or chronic exposure. There is growing evidence linking PCBs and other persistent halogenated aromatic hydrocarbons to reproductive and immunotoxic effects in wildlife. Effects on the liver, skin, immune system, reproductive system, gastrointestinal tract and thyroid gland of laboratory rats have been observed, and PCBs are classified as probable human cancer promoters.

HCB has been widely used as a pesticide to protect the seeds of onions and sorghum, wheat and other grains against fungus. HCB has been used as an intermediate or additive in various manufacturing processes, including the production of synthetic rubber, pyrotechnics and ammunition, dyes and pentachlorophenol. Today HCB is emitted primarily as by-products in industrial and combustion processes, but is also found in certain pesticides or chlorinated solvents (US EPA, 2000). HCB may also be found in ferric chloride used in precipitation processes during water or wastewater treatment (Danish Crown, 2006; DEPA, 200a and b, US EPA, 2000).

In addition to the above-mentioned sources, both PCBs and HCB are known to be formed through the same processes that create PolyChlorinated Dibenzo-p-Dioxins (PCDDs) and PolyChlorinated Dibenzofurans (PCDFs).

The current project is limited to a study of Annex $C$ compounds of the Stockholm Convention, of which the PCDDs and dibenzofurans have already been investigated elsewhere. Focus is on the unintentional formation and emission of the persistent organic pollutants (UPOPs) HCB and PCBs, from anthropogenic sources.

Ongoing and past actions and measures taken to monitor and reduce or eliminate the unintentional emission of HCB and PCBs are described as part of the National Implementation Plans (NIPs). All the Nordic countries have submitted their NIPs to the conference of parties in accordance with Article 7 of the Stockholm Convention (http://www.pops.int/documents/ implementation/nips/).

All countries have, at some level, adopted several BAT and BEP approaches with the purpose of limiting the emission of the abovementioned pollutants; e.g. technological developments driving the industry to apply best available techniques and to adopt processes that prevent emissions, as well as through waste management regulations. As observed in Table 1, the Nordic countries regulation of PCBs is far ahead of the requirements of the Convention, which calls for a phase-out by 2025 and final disposal by 2028. 
Table 1 National restrictions by law and in accordance with the requirements of the Stockholm Convention, Annex A

\begin{tabular}{|c|c|c|c|c|}
\hline $\begin{array}{l}\text { Restrictions } \\
\text { by law }\end{array}$ & Substance & Historical use & Last use / Phasing out & $\begin{array}{l}\text { Ban of } \\
\text { Export- } \\
\text { Import* }\end{array}$ \\
\hline \multirow[t]{2}{*}{ Denmark } & PCB & $\begin{array}{l}\text { Transformer oils, capacitors, } \\
\text { "open" use like paints, fillers, } \\
\text { self-copying paper }\end{array}$ & $\begin{array}{l}1977 \text { open use; } 1986 \text { ban on } \\
\text { sale of PCB and products } \\
\text { containing PCB; } 1995 \text { PCB- } \\
\text { containing capacitors and } \\
\text { transformers > } 1 \mathrm{~kg} \text { total } \\
\text { weight; } 2000 \text { ban on use and } \\
\text { storage of equipment contain- } \\
\text { ing PCB with a total weight } \\
>1 \mathrm{~kg}\end{array}$ & 1986 \\
\hline & $\mathrm{HCB}$ & Industrial use & $\begin{array}{l}1992 \text { ban of use as active } \\
\text { ingredient in pesticides; } 2003 \\
\text { total ban }\end{array}$ & \\
\hline \multirow[t]{2}{*}{ Finland } & PCB & $\begin{array}{l}\text { Transformer oils, capacitors } \\
\text { and sealants of prefabri- } \\
\text { cated homes }\end{array}$ & $\begin{array}{l}\text { 1970s; prohibition of manufac- } \\
\text { turing, marketing and use, } \\
1990\end{array}$ & $1990 / 2002$ \\
\hline & $\mathrm{HCB}$ & Pesticide & $\begin{array}{l}\text { 1976; prohibition of manufac- } \\
\text { turing, 2002; marketing, 2004; } \\
\text { use, } 1996\end{array}$ & 2002 \\
\hline \multirow[t]{2}{*}{ Norway } & PCB & $\begin{array}{l}\text { Capacitors and transformers, } \\
\text { insulating windows, in small } \\
\text { capacitors in fluorescent light } \\
\text { fixtures, in high voltage } \\
\text { equipment, } \\
\text { in capacitors in old radios and } \\
\text { in old construction materials } \\
\text { (as paints, sealed joints etc }\end{array}$ & $\begin{array}{l}\text { Production and use banned in } \\
\text { 1980; Use of bigger transfor- } \\
\text { mators and condensators } \\
\text { phased out in 1994-1995, } \\
\text { prohibited in } 1995 .\end{array}$ & \\
\hline & HCB & Pesticide & $\begin{array}{l}\text { 1979, use or place on the } \\
\text { market all plant protection } \\
\text { products containing hexa- } \\
\text { chlorobenzene prohibited }\end{array}$ & \\
\hline \multirow[t]{6}{*}{ Sweden } & PCB & $\begin{array}{l}\text { Power capacitors, switching } \\
\text { gear and transformer dielec- } \\
\text { tric fluid }\end{array}$ & $\begin{array}{l}1973 \text { open use banned } \\
1978 \text { 'new' uses in closed } \\
\text { applications banned }\end{array}$ & \\
\hline & & $\begin{array}{l}\text { Anti-skid flooring sealants } \\
\text { Insulation glass units }\end{array}$ & $\begin{array}{l}\text { 1988: stepwise reduction of } \\
\text { use in closed systems }\end{array}$ & \\
\hline & & Small capacitors & 1995: all use banned & \\
\hline & & Hydraulic fluids & 2013: contaminated sealants & \\
\hline & & $\begin{array}{l}\text { Carbonless copying paper } \\
\text { Chloro caoutchouk paint } \\
\text { Anti-fouling paint }\end{array}$ & $\begin{array}{l}\text { and flooring resins in buildings } \\
\text { to be removed }\end{array}$ & \\
\hline & HCB & $\begin{array}{l}\text { Voronit; fungicide for treat- } \\
\text { ment of seed (first registered } \\
\text { 1964) }\end{array}$ & $\begin{array}{l}\text { Production and use banned in } \\
1980\end{array}$ & \\
\hline
\end{tabular}

*Prohibited by adoption of the Basel Convention

Decontamination and/or disposal of all PCB-containing equipment should be completed before 2010 according to the EU PCB Directive and before 2028 according to the Stockholm Convention. Small capacitors and transformers may be used until the end of their useful economic life, with the WEEE Statutory Order requiring that components containing PCB in scrap electrical and electronic equipment must be removed from the products and destroyed. As such, the Nordic countries are ahead of the 
target years for phasing out $\mathrm{PCB} / \mathrm{HCB}$-containing products. An overview of the destruction of historic PCB-containing products and sources of emissions and waste treatment activities before 1998 may be found in the Inventory of Worldwide PCB Destruction Capacity (UNEP/SBC, 1998).

The Stockholm Convention requires parties to take measures to reduce or eliminate emissions of POPs from intentional production and use (Article 3), unintentional production (Article 5) and stockpiles and wastes (Article 6). Concepts of Best Available Techniques (BAT) and Best Environmental Practices (BEP) are to be further elaborated by the Conference of the Parties. Article 5 and 6 of the Stockholm Convention relate to the nature of the potential sources for emissions of HCB and PCBs.

In accordance with Article 6 of the Stockholm Convention, 'Measures to reduce or eliminate emissions from stockpiles and wastes', the parties to the convention are to cooperate closely with the appropriate bodies of the Basel Convention on the Control of 'Transboundary Movements of Hazardous Wastes and their Disposal' (Basel, 2005). Furthermore, countries are obliged to submit emission inventories as a measure of the reduced emissions of the unintentional POPs listed in Annex C of the convention; i.e. dioxins, PCBs and HCB.

Annex C, part V of the Stockholm Convention includes elements to be considered under prevention of the unintentional production and emission of PCBs and HCB. Furthermore, a revised version of the guidelines on BAT and BEP was released in December 2006 (Guidelines on BAT and Guidance on BEP, 2006), including, in addition to a description of processes that are UPOP sources, a description of control treatment processes and handling of residual product and waste characterization, sorting, recycling, etc. to secure that no UPOP re-enters the product cycle. Furthermore, the aim os that emissions upon final disposal or destruction of PCB- or chlorine-containing residual products are prevented and/or decreased to a maximum level by means of BEP and BAT approaches (Basel, 2007a and b). The threshold for emission of HCB and PCBs caused by unintentional formation processes at facility level is given in Table 2; the concentration in solid residues being classified as hazardous waste if the general definition of $50 \mathrm{mg} \mathrm{POP} / \mathrm{kg}$ waste is exceeded (Basel, 2005).

Both the Stockholm Convention and the LRTAP Protocol on longrange atmospheric transport are important tools in the process of reducing, with the final aim of eliminating, POPs as well as UPOPs. Potential sources of emissions of PCBs and HCB relate to UPOPs, i.e. Annex C of the Stockholm Convention, comprising unintentional formation and releases as impurities during various processes including industrial processes and nearly all types of combustion processes such as waste incineration, combustion of fuels and small scale burning of wood. From 2007, industry is obliged to report emissions of HCB and PCB at facility level to the E-PRTR. Existing sources that may result in unintentional 
formation and emissions of HCB and PCB, as listed in the Annex C of the Stockholm Convention, are as follows:

Industrial source categories according to Annex $\mathrm{C}$ of the Stockholm Convention, Part II, 'having the potential for comparatively high formation and release of these chemicals to the environment':

- Waste incinerators, including co-incinerators of municipal, hazardous or medical waste or of sewage sludge

- Cement kilns firing hazardous waste

- Production of pulp using elemental chlorine or chemicals generating elemental chlorine for bleaching

- The following thermal processes in the metallurgical industry:

(i) Secondary copper production

(ii) Sinter plants in the iron and steel industry

(iii) Secondary aluminium production

(iv) Secondary zinc production

Source categories according to Annex C of the Stockholm Convention, Part III, 'that may also unintentionally form and release' UPOPs:

- Open burning of waste, including burning of landfill sites

- Thermal processes in the metallurgical industry not mentioned in Part II

- Residential combustion sources

- Fossil fuel-fired utility and industrial boilers

- Firing installations for wood and other biomass fuels

- Specific chemical production processes releasing unintentionally formed persistent organic pollutants, especially production of chlorophenols and chloranil

- Crematoria

- Motor vehicles, particularly those burning leaded gasoline

- Destruction of animal carcasses

- Textile and leather dyeing (with chloranil) and finishing (with alkaline extraction)

- Shredder plants for the treatment of end of life vehicles

- Smouldering of copper cables

- Waste oil refineries

The lists of potential sources presented above are to some extent covered by the E-PRTR reporting format, which is presented at the beginning of Chapter 2. However, this format is designed for industry reporting obligations at facility level, e.g. transport is not included. The source categories listed in Part III of the Stockholm Convention are covered by sources originating from industrial activities or diffuse sources as defined in the E-PRTR guidelines. 
Chapter 2 presents an investigation existing information regarding activities that may fit into the individual types of industrial categories as defined in Annex 2 of the E-PRTR regulation (Table 2). In addition to the industrial point sources, diffuse sources have been included as defined in the E-PRTR protocol and described in more details by BiPRO (Beratungsgesellschaft für integrierte Problemlösungen). Potential sources for the Nordic countries, and identification of the country specific relevance of these, are presented in the Chapter 2.

In Chapter 3, the identified sources contributing to unintentional emissions of HCB and/or PCBs to air, soil or water, respectively, will be presented and estimated where possible together with existing data gaps. If emission factors are available, these are provided and indicative emission levels have been estimated in cases where activity data were available. In view of the limited resources within this project, European level datasets on potential sources were preferred as representing national activity data. National data and expert knowledge was included to secure correctness of the indicative nature of the data presented in this study where possible. All data presented in this study are to be seen as indicative measures as no uncertainty analysis or in depth quality assessment of the sources have been performed.

Chapter 4 presents the main conclusions regarding sources, data gaps and uncertainties and suggestions for further investigations in specific areas of this review regarding information on sources of release of HCB and PCBs to soil, water and air. 



\section{Identification of sources}

For the identification of sources of unintentional emissions of HCB and PCBs, the reporting guidelines under the Protocol on Pollutant Releases and Transfer Registers (PRTR) are used. The Protocol on Pollutant Release and Transfer Registers (PRTR) was adopted on 21 May 2003 during the fifth 'Environment for Europe' Ministerial Conference in Kiev (Regulation (EC) No 850/2004). The protocol, which applies to 36 European countries and the European Union, is the first legally binding international instrument on pollutant release and transfer registers. PRTRs are inventories of pollution released to all media by industrial sites and other sources. As such, the PRTRs implementing the PRTR Protocol will in the long run contain two types of data: facility-level data and data for socalled diffuse sources. A description of diffuse sources, e.g. road transport and domestic heating, where such data is available are presented in section 2.2., while potential sources to be reported in future at facility level are described as potential point sources in section 2.1. In general terms, data for the two types of sources must be integrated into an overall picture of emissions to air, water and land and off-site transfers of waste and of pollutants, here UPOPs, in wastewater (E-PRTR Regulation (EC) No 166/2006).

\subsection{Point sources}

Point sources are defined as facility-level emissions from facilities carrying out specific activities listed in Table 2 and defined in the E-PRTR Regulation (EC) No 166/2006 and guidelines for implementation of the E-PRTR at the European level (European Commission, 2006). The defined facility activities cover the industrial source categories listed in Annex C, Part II and III, of the Stockholm Convention, also provided in Chapter 1 of this study, as well sources within the Energy sector. Details concerning reporting obligations may be found in the E-PRTR guidelines (European Commission, 2006) and Article 7 of the Stockholm Convention.

Potential sources of HCB and PCBs release to air, water and land are marked by dots and crosses in Table 2. The dots are taken from the guidance document for reporting to the E-PRTR and represent indicative sector-specific sources to PCBs and HCB emissions to air and water (European Commission, 2006). The crosses have been added as a result of the present work and do not infer any judgement as to expected size of the potential source. This is in accordance to the E-PRTR regulation in which it is stated that if a facility is/was 'engaged in' an activity listed in Table 
2 , and the activity occurred at the facility at any time during the reporting year, then the releases, disposals and transfers of UPOPs must be considered regardless of the extent or the primary purpose of the facility; including fugitive and diffuse releases of facilities.

Air

HCB and PCB may be unintentionally formed during production processes as well as combustion processes in various industrial sectors (power production, waste incineration, metallurgical industry, cement production, domestic burning, etc.). De novo synthesis is especially important if certain catalysts (e.g. copper and lead) or chlorine precursors are present in the feed material and therefore a detailed knowledge of industrial production processes as well as combustion processes and feed material is needed to identify sources of emissions of HCB and PCBs. Available knowledge regarding activities and processes leading to unintentional production and emission of HCB and PCBs from different types of industrial facilities is presented below. The information has been extracted from the scientific literature as well as existing BAT and BEP guidelines, as well as reports relating to sources of PCB and HCB emission.

Water

The direct emission of UPOPs via effluents is regarded as insignificant or of minor importance as the relevant industries are assumed to be connected to the municipal sewer system or the wastewater is assumed to be effectively treated prior to release. It is expected that PCBs and HCB may potentially be sorbed to dust in the wastewater as well as other flue-gas cleaning and combustion residues. Thus, the centralized wastewater treatment plants may have been subjected to an increased influent load of organic matter and potentially PCB and HCB sorbed to dust from wetscrubbing processes.

Land

Releases to land apply only to pollutants in waste which is subject to the disposal operations 'land treatment' or 'deep injection' as defined in Article 6 of the E-PRTR Regulation (EC Regulation No 166/2006). Land treatment may result from the use of sludge as fertilizer in agricultural soils, whereas deep injection would result from 'injection of pumpable discards into wells, salt domes or naturally occurring repositories' (Guidance Document for European PRTR implementation, 2006).

Off-site transfer of waste, i.e. movement of waste fractions beyond the boundaries of a facility, destined for disposal or recovery is not included in this survey. As such, the project does not include any attempt to quantify off-site transfer of waste in any detail. Information on potential sources of unintentional emission of HCB and PCBs are mentioned in relation to recovery and disposal ( $\mathrm{R}$ and $\mathrm{D}$ ) treatment processes. 
Table 2 General overview of sources to emissions of PCBs and HCB to air, water and land

\begin{tabular}{|c|c|c|c|c|c|c|c|c|}
\hline & & \multirow{2}{*}{$\begin{array}{l}\text { Environmental matrix } \\
\text { Pollutant name }\end{array}$} & \multicolumn{2}{|c|}{ Air } & \multicolumn{2}{|c|}{ Water } & \multicolumn{2}{|c|}{ Land } \\
\hline & & & HCB & PCB & $\mathrm{HCB}$ & PCB & HCB & PCB \\
\hline & & $\begin{array}{l}\text { E-PRTR threshold for releases [kg/yr] (European } \\
\text { PRTR Regulation 166/2006/EC,Annex 2) }\end{array}$ & 10 & 0.1 & 1 & 0.1 & 1 & 0.1 \\
\hline \multirow[t]{7}{*}{1} & & Energy sector & & & & & & \\
\hline & (a) & Mineral oil and gas refineries & & $\mathrm{x}$ & & & & \\
\hline & (b) & Installations for gasification and liquefaction & $\mathrm{x}$ & $\mathrm{x}$ & & & & \\
\hline & (c) & $\begin{array}{l}\text { Thermal power stations and other combustion instal- } \\
\text { lations }\end{array}$ & $\mathrm{x}$ & $\mathrm{x}$ & & & & \\
\hline & (d) & Coke ovens & & & & & & \\
\hline & (e) & Coal rolling mills & & & & & & \\
\hline & (f) & $\begin{array}{l}\text { Installations for the manufacture of coal products and } \\
\text { solid smokeless fuel }\end{array}$ & & & & & & \\
\hline \multirow[t]{7}{*}{2} & & Production and processing of metals & & & & & & \\
\hline & (a) & $\begin{array}{l}\text { Metal ore (including sulphide ore) roasting or sintering } \\
\text { installations }\end{array}$ & & & & & & \\
\hline & (b) & $\begin{array}{l}\text { Installations for the production of pig iron or steel } \\
\text { (primary or secondary melting) including continuous } \\
\text { casting }\end{array}$ & & & & & & \\
\hline & (c) & Installations for the processing of ferrous metals & & & & & & \\
\hline & (d) & Ferrous metal foundries & & & & & & \\
\hline & (e) & $\begin{array}{l}\text { Installations for the production of non-ferrous crude } \\
\text { metals from ore, concentrates or secondary raw } \\
\text { materials by metallurgical, chemical or electrolytic } \\
\text { processes and for the smelting, including the alloying, } \\
\text { of non-ferrous metals, including recovered products } \\
\text { (refining, foundry casting, etc.) }\end{array}$ & & & & & & \\
\hline & (f) & $\begin{array}{l}\text { Installations for surface treatment of metals and } \\
\text { plastic materials using an electrolytic or chemical } \\
\text { process }\end{array}$ & & & & & & \\
\hline \multirow[t]{8}{*}{3} & & Mineral industry & & & & & & \\
\hline & (a) & Underground mining and related operations & & & & & & \\
\hline & (b) & Opencast mining and quarrying & & & & & & \\
\hline & (c) & $\begin{array}{l}\text { Installations for the production of cement clinker in } \\
\text { rotary kilns, lime in rotary kilns, cement clinker or lime } \\
\text { in other furnaces }\end{array}$ & $x$ & & & & & \\
\hline & (d) & $\begin{array}{l}\text { Installations for the production of asbestos and the } \\
\text { manufacture of asbestos-based products }\end{array}$ & & & & & & \\
\hline & (e) & $\begin{array}{l}\text { Installations for the manufacture of glass, including } \\
\text { glass fibre }\end{array}$ & & & & & & \\
\hline & $(\mathrm{f})$ & $\begin{array}{l}\text { Installations for melting mineral substances, including } \\
\text { the production of mineral fibres }\end{array}$ & & & & & & \\
\hline & (g) & $\begin{array}{l}\text { Installations for the manufacture of ceramic products } \\
\text { by firing, in particular roofing tiles, bricks, refractory } \\
\text { bricks, tiles, stoneware or porcelain }\end{array}$ & $x$ & $\mathrm{x}$ & & & & \\
\hline \multirow[t]{6}{*}{4} & & Chemical industry & & & & & & \\
\hline & (a) & $\begin{array}{l}\text { Chemical installations for the production on an indus- } \\
\text { trial scale of basic organic chemicals }\end{array}$ & & & & & & \\
\hline & (b) & $\begin{array}{l}\text { Chemical installations for the production on an indus- } \\
\text { trial scale of basic inorganic chemicals }\end{array}$ & & & & & & \\
\hline & (c) & $\begin{array}{l}\text { Chemical installations for the production on an indus- } \\
\text { trial scale of phosphorous-, nitrogen- or potassium- } \\
\text { based fertilizers (simple or compound fertilizers) }\end{array}$ & & & & & & \\
\hline & (d) & $\begin{array}{l}\text { Chemical installations for the production on an indus- } \\
\text { trial scale of basic plant health products and of } \\
\text { biocides }\end{array}$ & & & & & & \\
\hline & (f) & $\begin{array}{l}\text { Installations for the production on an industrial scale } \\
\text { of explosives and pyrotechnic products }\end{array}$ & & & & & & \\
\hline
\end{tabular}




\begin{tabular}{|c|c|c|c|c|c|c|c|c|}
\hline & & \multirow{2}{*}{$\begin{array}{l}\text { Environmental matrix } \\
\text { Pollutant name }\end{array}$} & \multicolumn{2}{|c|}{ Air } & \multicolumn{2}{|c|}{ Water } & \multicolumn{2}{|c|}{ Land } \\
\hline & & & $\mathrm{HCB}$ & РCB & $\mathrm{HCB}$ & PCB & HCB & PCB \\
\hline 5 & & Waste and wastewater management & & & & & & \\
\hline & (a) & $\begin{array}{l}\text { Installations for the disposal or recovery of hazardous } \\
\text { waste }\end{array}$ & & $\mathrm{x}$ & & & & \\
\hline & (b) & $\begin{array}{l}\text { Installations for the incineration of non-hazardous } \\
\text { waste in the scope of Directive } 2000 / 76 / E C \text { of the } \\
\text { European Parliament and of the Council of } 4 \text { Decem- } \\
\text { ber } 2000 \text { on the incineration of waste (2) }\end{array}$ & & $\mathrm{x}$ & & & & \\
\hline & (c) & Installations for the disposal of non-hazardous waste & & $\mathrm{x}$ & & & & \\
\hline & (d) & $\begin{array}{l}\text { Landfills (excluding landfills for inert waste and } \\
\text { landfills, which have been definitely closed before the } \\
16.7 .2001 \text { or for which the after-care phase required } \\
\text { by the competent authorities according to Article } 13 \text { of } \\
\text { Council Directive } 1999 / 31 / \text { EC of } 26 \text { April } 1999 \text { on the } \\
\text { landfill of waste (3) has expired) }\end{array}$ & & $\mathrm{x}$ & & & $\mathrm{x}$ & $\mathrm{x}$ \\
\hline & (e) & $\begin{array}{l}\text { Installations for the disposal or recycling of animal } \\
\text { carcasses and animal waste }\end{array}$ & & & & & & \\
\hline & (f) & Urban waste-water treatment plants & & $\mathrm{x}$ & & & & \\
\hline & (g) & $\begin{array}{l}\text { Independently operated industrial waste-water treat- } \\
\text { ment plants which serve one or more activities of this } \\
\text { annex }\end{array}$ & $\mathrm{x}$ & $\mathrm{x}$ & & & & \\
\hline 6 & & Paper and wood production and processing & & & & & & \\
\hline & (a) & $\begin{array}{l}\text { Industrial plants for the production of pulp from timber } \\
\text { or similar fibrous materials }\end{array}$ & & & & & & \\
\hline & (b) & $\begin{array}{l}\text { Industrial plants for the production of paper and board } \\
\text { and other primary wood products (such as chipboard, } \\
\text { fibreboard and plywood) }\end{array}$ & & & & $\mathrm{x}$ & & \\
\hline & (c) & $\begin{array}{l}\text { Industrial plants for the preservation of wood and } \\
\text { wood products with chemicals }\end{array}$ & & & & & & \\
\hline 7 & & Intensive livestock production and aquaculture & & & & & & \\
\hline & (a) & Installations for the intensive rearing of poultry or pigs & & & & & & \\
\hline & (b) & \begin{tabular}{|l|l} 
Intensive aquaculture \\
\end{tabular} & & & & & & \\
\hline 8 & & $\begin{array}{l}\text { Animal and vegetable products from the food and } \\
\text { beverage sector }\end{array}$ & & & & & & \\
\hline & (a) & Slaughterhouses & & $\mathrm{x}$ & & & & \\
\hline & (b) & $\begin{array}{l}\text { Treatment and processing intended for the production } \\
\text { of food and beverage products from animal raw } \\
\text { materials (other than milk) and vegetable raw materi- } \\
\text { als }\end{array}$ & & & & & & \\
\hline & (c) & Treatment and processing of milk & & & & & & \\
\hline 9 & & Other activities & & & & & & \\
\hline & (a) & $\begin{array}{l}\text { Plants for the pre-treatment (operations such as } \\
\text { washing, bleaching, mercerization) or dyeing of fibres } \\
\text { or textiles }\end{array}$ & & & & & & \\
\hline & (b) & Plants for the tanning of hides and skins & & & & & & \\
\hline & (c) & $\begin{array}{l}\text { Installations for the surface treatment of substances, } \\
\text { objects or products using organic solvents, in particu- } \\
\text { lar for dressing, printing, coating, degreasing, water- } \\
\text { proofing, sizing, painting, cleaning or impregnating }\end{array}$ & & & & & & \\
\hline & (d) & $\begin{array}{l}\text { Installations for the production of carbon (hard-burnt } \\
\text { coal) or electrographite by means of incineration or } \\
\text { graphitization }\end{array}$ & & & & & & \\
\hline & (e) & $\begin{array}{l}\text { Installations for the building of, and painting or re- } \\
\text { moval of paint from ships }\end{array}$ & & & & & & $\mathrm{x}$ \\
\hline
\end{tabular}

Possible production processes which may result in potential emissions of HCB and/or PCBs have been reviewed with reference to the existing literature, reports and databases. Emission factors for potential sources to unintentional emissions of PCBs and HCB have been extracted from the literature and guidance documents, such as: 
- The Corinair Guidebook (EMEP, 2006)

- The IPPC (Integrated Pollution Prevention and Control) BREFs (Best available techniques REFerence documents)

- Draft guidelines on best available techniques and provisional guidance on best environmental practices relevant to Article 5 and Annex $C$ of the Stockholm Convention

- The technical guidelines on the environmentally sound management of wastes prepared under the Basel Convention on the Control of Transboundary Movements of Hazardous Wastes and their Disposal

- The scientific literature

Activity data for potential sources of unintentional emissions of PCBs and HCB have been extracted from official national statistics as well as Nordic or European databases. Selected data sources are listed below:

- National Inventory Reports from the EIONET website

- CRF tables from the UNFCCC website

- European Association of Mining Industries at http://www.euromines.org/

- International Solid waste association at http://www.iswa.org/web/guest/home

- European asphalt pavement association at http://www.eapa.org/

- Nordic Waste Info at www.nordic-waste.info

- Statistics Norway

- Statistic Finland

- Statistics Sweden

- Statistics Denmark

- EUROSTAT

Below a short description including the relevance of the E-PRTR activities for the Nordic countries is presented with reference to literature and references on specific processes which may lead to emission of PCBs and HCB. Processes identified in accordance with the categories as given in Table 2 have been verified by data on specific activities and/or emission factors. Activity data representative for potential sources are presented in Chapter 2, emission estimates and emission factors are presented in Chapter 3 and supporting material in Annex 1 to 6. The resources available for this project do not allow for in-depth quality assurance and assessment of data sources at national or plant-specific process levels. As such, focus is on the compilation and review of existing knowledge on the potential sources of unintentional emissions of HCB and PCBs, rather than delivering an inventory of unintentional emissions of these substances. 


\subsubsection{The Energy Sector}

Oil refineries (PRTR code 1a)

The reference document on BAT for Mineral Oil and Gas Refineries (IPPC BREF MOGR, 2003) describes the dioxin emission to air as well as to wastewater during wet scrubbing processes. Electrostatic precipitator and activated carbon filters are among the flue-gas cleaning techniques mentioned as BAT prior to emission of the flue gas. PCBs are mentioned as potential contaminants in waste lubricants (IPPC BREF MOGR, 2003), but no emission factors are provided.

According to available information from the U.S. Geological Survey Mineral Information, Finland and Sweden have no production of crude petroleum (see Annex 1, Table 1.6), but do have refining processing activities as listed in Table 3. According to Table 3 the activity data for Norway and Sweden are approximately a factor of two above the activity data for Finland and Denmark. Petroleum refining is reported to be a potential source of unintentional PCB emission (BiPRO, 2006).

Table 3 Activity data on amounts of petroleum refinery products produced within in the Nordic countries [tonnes]

\begin{tabular}{lrrrrrr}
\hline & 2001 & 2002 & 2003 & 2004 & 2005 & Reference \\
\hline Denmark & 9820800 & 7890058 & 8143080 & 8156720 & 8320400 & 1 \\
Finland & 5772175 & 7474856 & 7495998 & 8325447 & 10747774 & 1 \\
Norway & 17595600 & 17732000 & 18004800 & 14066114 & 15408290 & 1 \\
Sweden & 21005600 & 21278400 & 21414800 & 21687600 & 21960400 & 1 \\
Sweden* $^{1}$ & 19592850 & 19313700 & 19661650 & 20611900 & 19920000 & 2 \\
\hline
\end{tabular}

References:

1: US Geological survey, http://minerals.usgs.gov/minerals/pubs/country/europe.html

2: National expert knowledge

Given the available data, air emissions from the petroleum industry represent an important source of PCB air emissions in the Nordic countries. Petroleum industry wastes may include significant concentrations of PCB (e.g. Frank J. Castaldi, P.E., 2004).

Alternative and secondary fuels for energy production (PRTR code 1b)

New approaches for producing energy from different types of wastes and residues are likely in the future. As such, the PRTR sub-category 1.b may very well take on greater importance in years to come. However, these activities are currently still in the pilot phase and therefore only scarce information on these processes is available at present (Belgiorno et al, 2003; Ratafia-Brown et al, 2002). Gasification is particularly suitable for treatment of industrial wastes, but a number of problems exist with municipal solid wastes (MSW) due to their heterogeneity. Energy from gasification of different types of waste may contribute to emission of soluble pollutants in wastewater in wet scrubber and gas cooling processes as well contaminants in solid residues. The presence of HCB/PCBs in these 
by-products and residues depends entirely on the feed material, e.g. paper mill waste, mixed plastic waste, forest industry waste and agricultural residues, and the subsystems employed to deal with releases into the environment (Belgiorno et al, 2003; Kikuchi et al., 2007; Pegg et al., 2007).

Gasification of coal and oil currently takes place to a certain degree, while the conversion of biomass to energy as well as gasification as an alternative to thermal treatment of waste are both fairly new. For MSW and refuse-derived fuel (RDF), pyrolysis and gasification stand-alone applications, in Europe, are still in the premature stages. However, largescale pyrolysis and gasification applications, combined with combustion, are already in place in Sweden and Finland (Malkow, 2004). New approaches to using e.g. pyrolysis of waste and organic materials to produce solid, liquid and gaseous fuels for energy may increase; e.g. driven by new technologies and waste strategies at national and EU level, based on selection, recycling and energy recovery (Hedman et al., 2005; Baggio et al., 2008).

Further knowledge on these new technologies and potential unintentional emissions of HCB and PCBs from waste-to-energy production processes in the Nordic countries is required.

As far as the authors are aware, no statistics on the use of secondary fuels for energy production are available at this stage of development and therefore this source can only be assessed as an emerging, and expected, growing industry.

Large combustion plants (PRTR code 1 c)

Information from the IPPC reference document on BAT for large combustion plants (IPPC BREF LCP, 2006) includes an emission factor of 11 $\mathrm{mg} / \mathrm{Nm}^{3}$ for PCB emissions to air from biomass-fired atmospheric fluidized bed combustion (AFBC) plants with a capacity of 100-300 $\mathrm{MW}_{\text {th }}$. The emissions from large combustion plants are divided into capacity ranges of 50-100 and 100-300 $\mathrm{MW}_{\text {th }}$, respectively, and no PCB emissions are reported for the low-range capacity combustion plants. To the knowledge of the authors this type of plant no longer operates in any of the Nordic countries. No emission for HCB is included in the BAT document (IPPC BREF LCP, 2006). However, available information concerning sources of unintentional emissions of HCB and PCBs and their correlation to dioxin emissions does not support that there will be no HCB emission from either of the two size categories of large combustion plants, or that PCBs will only be emitted from the high-range capacity combustion plants (Kenichi et al., 2002).

The document (IPPC BREF LCP, 2006) indicates that co-combustion of sewage sludge does not increase the flue-gas concentration of PCBs; in fact, the PCB concentration seems to be lowest in the flue gas with sewage sludge co-combustion - $8.25 \mathrm{ng} / \mathrm{m}^{3}$ - versus $9.8 \mathrm{ng} / \mathrm{m}^{3}$ without sewage sludge co-combustion. An explanation may be that the factor governing the 
UPOP concentration in flue gas is determined by the level of application of air pollution control devices (APCD) and other combustion process parameters (e.g. Andrijewski, M. et al., 2004). The energy sector may contribute to the unintentional emission of HCB and PCBs to air, depending on the feed material used for energy production, when comparing plants of the same size and with similar technological characteristics.

Even if PCBs are present as contaminants in secondary fuels but destroyed in the combustion chamber, they may be reformed or de novo synthesized. De novo synthesis of PCBs is possible due to the presence of non-chlorinated precursors where there is an associated supply of inorganic chlorine substances in the secondary fuels, such as demolition wood or refuse-derived fuel (RDF). HCB and PCB emissions may, as in the case of dioxin emissions, be reduced by means of injection of an activated carbon into the flue gas.

Emissions of dioxins and furans from coal-fired plants are low due to their specific combustion characteristics and the sulphur content of the fuel, which inhibits the formation of these compounds; this may also be true for the formation of PCBs (Leclerc et al., 2006). This does not change with co-combustion, even with a secondary fuel with high chlorine content (IPPC BREF LCP, 2006; Leclerc et al., 2006). Technological developments may even further decrease the de novo formation of UPOPs (Pandelova et al., 2006; Ishikawa et al., 2007).

A recent study has shown that the dioxin emissions from 17 different combustion categories are approximately linearly correlated with the copper and chlorine content of the feed material, whereas the dioxin emissions are linearly inverse in relation to the average content of sulphur in the feed material (Thomas and McCreight, 2007). Kim et al. (2004) have shown that PCB and dioxin represent $7 \%$ and $9 \%$ respectively of the HCB stack emission. The study by Kenichi et al. supports the correlation of HCB and PCB, respectively, to measured dioxin emissions in the flue gas of industrial waste incinerators. The above-mentioned investigations include different types of waste which are of relevance for PRTR category $5 \mathrm{a}-\mathrm{c}$ as well (see section 5 Waste and wastewater management in Table 2).

It is outside the scope of this study to address the facility-specific activity data and therefore the emission estimates from the Energy sector are based on fuel consumption from the most recent submission to the UNFCCC (see Annex 1). PCB and HCB emissions from the Energy sector are based on available information on fuel consumption reported by the individual countries; extracted from national inventory reports of the CRF (Common Reporting Format) tables. The use of alternative fuels is not included in the screening level air emission estimates included in this study.

For all the Nordic countries, unintentional emissions of HCB and PCB from combustion are likely to be of importance. The higher activity data 
for energy production from combustion of municipal solid waste for Sweden and Denmark may result in the unintentional emission from energy production contributing to a greater degree to the total PCB and HCB emission in these countries compared with Finland and Norway. The lower consumption of coal for Norway and Sweden compared with Denmark and Finland may be explained by the alternative energy sources available in the former in terms of hydro and nuclear power.

Table 4 Fuel consumption for Energy production for 2005, divided into the fuel types municipal solid waste, coal and wood [tonnes]

\begin{tabular}{lrrr}
\hline \multicolumn{1}{c}{ Source sector* } & \multicolumn{2}{c}{ Fuel type } \\
\hline 1. Energy Industries & & & \\
a. Public Electricity and Heat Production & Coal & Wood** & MSW \\
Denmark & 5904545 & 1358527 & 3316932 \\
Finland & 3053373 & 6995210 & 361290 \\
Norway & 47000 & 151000 & 697000 \\
Sweden & 426902 & 7659748 & 3250000 \\
2. Manufacturing Industries and Construction & Coal & Wood* & MSW \\
Denmark & 306480 & 309362 & 184000 \\
Finland & 1132549 & 13802605 & NO \\
Norway & 110200 & 548700 & 94000 \\
Sweden & 414223 & 4820756 & NO \\
\hline
\end{tabular}

NO: Not occurring

*IPCC nomenclature

**may include wood waste (national expert knowledge)

References:

National expert knowledge and Inventory Reports submitted in 2007 http://unfccc.int/national_reports/annex_i_ghg_ inventories/national_inventories_submissions/items/3929.php

Details of available emission factors are provided in Annex 1, while emission estimates are provided in Chapter 3.

According to Bailey (2001), coal combustion is the third-largest global source of HCB emission. Still, fossil fuel combustion is suggested to produce a much lower level of UPOPs compared to waste-derived fuels (Sloss and Smith 1993; Sloss 2001; Dyke 2004), due to the inhibiting effect of sulphur on the do novo synthesis of HCB and PCBs. Sulphur is suggested to inhibit the formation of chlorinated UPOPs by two mechanisms: the presence of $\mathrm{SO}_{2}$ depletes molecular chlorine through a gas-phase reaction and $\mathrm{SO}_{2}$ reacts with copper $\left(\mathrm{CuO}\right.$ and $\left.\mathrm{CuO}_{2}\right)$ to produce $\mathrm{CuSO}_{4}$. Thereby the presence of sulphate is suggested to deplete molecular chlorine as well and the presence of copper as a catalyst for de novo synthesis of HCB and PCBs (Raghunathan and Gullett, 1996). The sulphur-to-chlorine ratio in coal is around of 5 to 1 , which is much greater than that found in municipal solid waste, thus preventing the formation of chlorinated aromatics which arise in the combustion wastederived fuels where chlorine dominates over sulphur (Mobbs, 2005). The chloride content of individual fuel types is given in Annex 4. 
The above parameters refer to non-optimally operated combustion systems. In properly operated combustion systems, volatiles are subject to high temperatures for sufficient time, with adequate oxygen and mixing, to enable uniform and complete combustion. When those conditions are not present, PCBs and HCB (similar to dioxins) may be formed by de novo synthesis or survive the combustion process (Van Remmen 1998; UNEP 2003) and result in unintentional emissions to air. According to e.g. Zevenhoven and Kilpinen (2001), de novo formation is determined by:

- The cooling rate of the flue gas, especially around $300^{\circ} \mathrm{C}$

- The amount of fly ash

- The presence of trace elements, especially $\mathrm{Cu}$ and $\mathrm{Pb}$

- The carbon and chlorine content of the fly ash

- The presence of free oxygen

Solid residues, in terms of ashes and slag are a by-product of the combustion processes (e.g. Dyke, 2002) and may potentially release PCBs and HCB. The reported concentration in residue products from combustion based on coal only and sewage sludge co-combustion is $0.02 \mu \mathrm{g} / \mathrm{kg}$ residue product (IPPC BREF LCP, 2006).

In Table 5, an example of off-site transfer of residue products from combustions processes within the energy sector is provided.

Table 5 Extracts from reuse categories in the Danish waste statistics, with focus on residues from combustion with energy production [1,000 tonnes]

\begin{tabular}{lrrrrrrrr}
\hline \multicolumn{1}{c}{ Year } & 1995 & 1996 & 1998 & 2000 & 2002 & 2003 & 2004 & 2005 \\
\hline $\begin{array}{l}\text { Fly ash and slag from coal } \\
\text { combustion plants, inclusive } \\
\text { bioash }\end{array}$ & 1276 & 1213 & 859 & 770 & 802 & 1090 & 851 & 783 \\
$\begin{array}{l}\text { Fly ash and slag from other } \\
\text { sources except for combustion }\end{array}$ & 3 & 2 & 2 & 1 & 60 & 54 & 60 & 59 \\
\begin{tabular}{l} 
Flue-gas cleaning products \\
\hline
\end{tabular} & 288 & 416 & 400 & 406 & 388 & 323 & 329 & 270 \\
\hline
\end{tabular}

Reference: Danish waste statistics 2005 (DEPA, 2006b)

The Danish waste statistics, in addition to the figures shown in Table 5, report fly ash disposed of to landfill (DEPA, 2006b). Definitions of waste, residue products or when waste becomes a new product and the relationship to reuse, recovery and recycling processes are not within the scope of this study. Still, life-cycle analysis of end-of-pipe products or waste is of importance for determining mass flows and potential releases to soil and water as well as the risk of UPOPs re-entering the product cycles. According to a quality report for statistics on generation and recovery and disposal of waste in Sweden, ashes, slag and mineral waste from combustion processes are either disposed of at landfill or used as construction material in e.g. roads (Swedish Environmental Protection Agency, 2006). Off-site transfer from the Energy sector may contribute to 
the diffuse source category 'Roofing and road paving with asphalt' as described in section 2.2.1.

Technological improvements in combustion and incineration processes towards higher DRE suggest a decrease in potential emissions to air. Information regarding potential releases with solid residues and waste streams, and with dust in wastewater, is limited (e.g. BiPRO, 2006). In general, point source releases in effluent are of minor importance due to the limited solubility of the UPOPs. UPOP-contaminated dust in the water used in wet scrubbing of flue gas may be a potential source of HCB and PCB release via separate effluent from industry.

To the extent of the knowledge of the authors, consideration of industrial plants categorized under the PRTR subcategories, Coke ovens (PRTR code 1d), Coal rolling mills (PRTR code 1e) and Installations for the manufacture of coal products and solid smokeless fuel (PRTR code 1f), is not relevant as these activities either do not occur or are not relevant in relation to unintentional sources of HCB and PCBs in the Nordic countries.

\subsubsection{The Metal Industry}

Potential sources of emission vary widely depending on the type of processes and technological aspects of the production processes involved. Therefore there is no straightforward way of calculating or assigning emission factors to the different production processes within the metal industry. Detailed data based on available knowledge produced during this project are given in Annex 2. Data may be incomplete due to the limited knowledge of the authors regarding the specific industries present in the other Nordic countries and the timeframe of the project.

Activity data for the production of ferrous and non-ferrous metals have been extracted from the European Association of Mining Industries, the US Geological Survey and national expert knowledge and statistics (see Annex 2, Table 2.1). A description of relevant sources is given below.

Iron and steel production (PRTR 2b)

For steel production a very important factor is whether the steel is produced from primary metals or from scrap metal (secondary metal production), with the latter giving rise to much higher dioxin emissions and therefore presumably also HCB/PCB emissions. PCBs can be formed in trace amounts from chlorinated precursors in thermal processes such as scrap metal recycling. The iron and steel industry is a highly material- and energy-intensive industry. More than half of the mass input becomes output in the form of off-gases and solid wastes/by-products. As a result, significant emissions are associated with the iron and steel industrial sector.

The types of plant involved in the main processing steps in pig iron and steel production are coke plants, sinter plants, blast furnaces, basicoxygen furnaces and electric arc furnaces (EAFs). To the knowledge of 
the authors only sinter plants and EAFs are in operation in the Nordic countries. Knowledge of potential sources from these two plant types are given below. For the remaining plant types no emissions of HCB or PCB are included in the IPPC BREF document (IPPC IS, 2001).

\section{Sintering plants}

High concentrations of a full range of PCB congeners/homologues have been measured in the atmosphere close to sintering strands (Alcock et al., 1999) and local soil pollution as well as groundwater pollution are other matters of concern for the iron and steel industry (IPPC, IS, 2001).

The IPPC BREF note on iron and steel production (IPPC IS, 2001) provides an emission factor of 1-13 mg/t liquid (LS) produced, with 2,100 $\mathrm{m}^{3}$ off-gas/t sinter.

Sinter plants produce residues or by-products in the range of 0.9-15 $\mathrm{kg}$ dust / $\mathrm{t}$ LS and $0.3 \mathrm{t}$ sludge / $\mathrm{LS}$. Moreover, use of hexachloroethane for removing magnesium from the melt may result in high HCB concentrations in the off-gas and dust contamination. However, the use of hexachloroethane is no longer applied in the EU (Guidelines on BAT and Guidance on BEP, 2006).

Emissions to water may occur from sinter plants using rinsing water techniques, cooling waters, which are usually recycled, and wastewater from gas treatment.

\section{Electric arc furnaces (EAF)}

For electric arc furnaces the emission in the primary gas is in the range of 1,500-45,000 $\mu \mathrm{g}$ PCB/t LS and 3,000-37,000 $\mu \mathrm{g}$ chlorobenzenes/t LS; the latter includes all chlorobenzenes except for monobenzene. The treatment processes within the metal industry also produce secondary emissions, including dust that also contributes to the HCB and/or PCB emissions if present in the primary gas.

Collected dust from off-gases is largely disposed of at landfill, but this depends on national laws governing legal requirements with regard to reuse. At modern EAF off-gas systems it is possible, with a fabric filter, to reach a clean gas dust concentration of less than $7 \mathrm{mg} / \mathrm{Nm}^{3}$. In addition, processing of slag includes cooling by water; with the slag being reused and thereafter disposed of as landfill. 
Table 6 Activity data on production processes of relevance for potential sources to $\mathrm{HCB}$ and PCB emissions [tonnes]

\begin{tabular}{|c|c|c|c|c|c|c|}
\hline Plant type & 2001 & 2002 & 2003 & 2004 & 2005 & Reference \\
\hline \multicolumn{7}{|c|}{ Sinter plants } \\
\hline Denmark & NO & NO & NO & NO & NO & 3 \\
\hline Finland & 2650000 & 2573693 & 2815000 & 2782000 & 2857000 & 1 \\
\hline Norway & 60000 & 80000 & 90000 & 90000 & 90000 & 1 \\
\hline Sweden & 3725100 & 3815100 & 3816100 & 3992000 & 3844000 & 3 \\
\hline \multicolumn{7}{|c|}{ Electric arc furnaces } \\
\hline Denmark & 746000 & 392000 & NO & NO & NO & 1 \\
\hline Finland & 3938000 & 4003000 & 4766000 & 4833000 & 4738000 & 2 \\
\hline Norway & 635000 & 694000 & 698000 & 695000 & 690000 & 1 \\
\hline Sweden & 1870100 & 1941000 & 1819000 & 1874000 & 1802000 & 3 \\
\hline
\end{tabular}

NO: Not Occurring

References:

1: US Geological survey; http://minerals.usgs.gov/minerals/pubs/country/europe.html; Finland: Association of Finnish Steel and Metal Producers

2: Association of Finnish Steel and Metal Producers

3: National expert knowledge

Denmark has no sintering plants, Finland has one, whereas Norway and Sweden have higher activity data regarding sintering and are therefore likely to have more sinter plants. Denmark has one electric arc furnace (EAF) and Finland two, while Sweden had around 11 EAFs in 1997 (IPPC BREF ISI, 2001). Finland has more EAFs in foundries, but only one in operation in iron and steel production plants. Denmark's only iron and steel production plant closed down in 2002 as can be observed from the figures in Table 6. Only sinter plants and EAFs are reported to be sources of emissions of HCB and PCB within the iron and steel production plants; therefore only these activities are included.

Of the Nordic countries, the majority of activity regarding iron and steel production occurs in Sweden and Finland, and only to a minor extent in Norway. For Denmark, there are no potential sources of unintentional emissions of HCB and PCBs from iron and steel production.

Ferrous metal industry (PRTR 2c and d)

Processing in the ferrous metal industry includes elemental chlorine, but very little information about the production of unintentional POPs is addressed in the IPPC reference document on the best available techniques (IPPC, BREF FMPI, 2001). Denmark has no ferrous metal foundries and the degree to which Norway, Sweden and Finland have plants for the processing of ferrous metals is unclear. The only sources included in this study are the sinter and EAF operating plants in relation to the processing of pig iron and steel, as well as coke production as provided in Table 7.

Potential sources to emissions may also occur from further processing of alloys, including e.g. wrought iron and scrap iron. Potential soil contamination from ferrous foundry raw materials arises from external storage of the scrap on soil. Contaminants of concern are oils that may in- 
clude PCBs from capacitors; mainly shredded scrap with risk of washing out to the groundwater and nearby surface water (IPPC BREF SFI, 2005).

Activity data for coke production within the iron and steel industry are only relevant for Finland and Sweden and relate only to the emission of PCB (BiPRO, 2006).

Table 7 Activity data on coke production figures as potential sources to PCB emissions [tonnes]

\begin{tabular}{lrrrrrr}
\hline Coke production & $\mathbf{2 0 0 1}$ & $\mathbf{2 0 0 2}$ & $\mathbf{2 0 0 3}$ & $\mathbf{2 0 0 4}$ & $\mathbf{2 0 0 5}$ & Reference \\
\hline Denmark & NO & NO & NO & NO & NO & 1 \\
Finland & 909000 & 912000 & 895217 & 903723 & 893628 & 2 \\
Norway & NO & NO & NO & NO & NO & 1 \\
Sweden & 1184900 & 1073300 & 1059700 & 1179000 & 1188000 & 3 \\
\hline
\end{tabular}

References:

1: US Geological survey; http://minerals.usgs.gov/minerals/pubs/country/europe.html

2: Association of Finnish Steel and Metal Producers

3: National expert knowledge

As observed from Table 7, the activity in coke production corresponds to the high activity in iron and steel production, coke production being associated with ferrous metal processing.

Potential emissions from production processes at foundries for the production of non-ferrous metals are described below. Production statistics used as activity data for the screening level estimation of emissions of HCB and PCBs from these industrial activities are given in Table 2.1 in Annex 2.

Non-ferrous metal industry (PRTR code 2e)

Potential emissions associated with the production of non-ferrous metals are related to the use of secondary raw materials including chlorine and therefore the potential for formation and release of UPOPs via the offgases from the various furnaces and transfers. APCD to capture dust in the off-gas and/or afterburning techniques to increase the DRE of UPOPs in the off-gas will reduce any unintentional emissions (IPPC, BREF on NFMI, 2001).

The presence of precursors, especially $\mathrm{Pb}$ and $\mathrm{Cu}$, for the formation of PCBs and HCB during pyro-metallurgical processes to produce nonferrous metals is a potential source of air emissions. Off-gas, i.e. gas produced during process stages such as sintering or roasting, smelting and casting, may include de novo produced chlorinated aromatics such as PCBs and HCB, therefore capturing and cleaning is needed to reduce potential emissions. Some non-ferrous metals, e.g. copper and lead, are reported to catalyse de novo synthesis. Therefore, a clean gas and quality control of the scrap used as feed material for non-ferrous metal production will decrease the risk of de novo formation of UPOPs due to precursor impurities in the off-gas. Treatment methods such as electrostatic filters, scrubbing and afterburning will reduce potential releases from 
residues such as furnace linings, sludge, filter dust and slag (IPPC, BREF on NFMI, 2001). As such, emission factors may vary accordingly.

Primary non-ferrous metal production is not associated with major dioxin emissions to air and therefore is expected to be of no concern for de novo production of HCB and PCBs.

Secondary aluminium

Secondary aluminium producers recycle aluminium from aluminiumcontaining scrap. The production process includes therefore pre-treatment cleaning processes, which are based on mechanical, pyro-metallurgical and hydrometallurgical techniques that lead in varying degrees to dioxin emissions. Therefore secondary aluminium production also results in the formation and release of HCB and PCBs. Finland reports a off-gas reduction efficiency of $51 \%$ for HCB with a concentration of $5.78 \mu \mathrm{g} / \mathrm{m}^{3}$ before filtering and $2.66 \mu \mathrm{g} / \mathrm{m}^{3}$ after the filter (Saarinen et al, 2007).

Magnesium production

Production of magnesium from magnesium chloride by electrolysis may result in the generation of dioxins/furans and HCB. The only Nordic country producing magnesium is Norway and this production ceased in 2001, when the Norwegian transnational company, Norsk Hydro, moved its magnesium production (www.hydromagnesium.com) from Norway to China. This indicates that this source is no longer relevant for the Nordic countries and corresponds to the fact that magnesium production was reported only for Norway, and only in the years 2001 and 2002 (European Association of Mining Industries).

Copper production

The sources of potential emissions of dioxin, and by assumption therefore PCBs and HCB, from the copper production processes are scrap treatment and smelting according to the IPPC BREF document (IPPC, BREF, NFMI, 2001). Secondary smelting processes in copper production may use computer scrap and printed circuit boards as copper source. Therefore the pre-treatment of scrap by both the scrap industry and by some smelters influences the emission potential. Secondary smelters are more prone to fugitive emissions during charging and tapping cycles. Secondary copper smelting and refining are included in the Finnish HCB air emission inventory (Saarinen et al., 2007) and are on the list of major sources according to the Stockholm Convention.

Precious metals

The recovery of precious metals from secondary raw materials is particularly important and many of these materials are classified as wastes from other industries. Advanced processing techniques are used to contain these materials and the small scale of production allows these techniques 
to be used effectively to minimize and abate potential emissions (IPPC, BREF, NFMI, 2001).

Finland, Sweden and Norway are involved in production of other metals, but for these processes no information regarding PCB or HCB emissions are available (e.g. BiPRO, 2006; Saarinen et al, 2007; IPPC, BREF NFMI, 2001).

Table 8 Activity data for the non-ferrous metal industry [tonnes]

\begin{tabular}{|c|c|c|c|c|c|c|}
\hline Production processes & 2001 & 2002 & 2003 & 2004 & 2005 & Reference \\
\hline \multicolumn{7}{|l|}{ Secondary Aluminium } \\
\hline Denmark & 18000 & 18000 & 18000 & 20000 & 20000 & 1 \\
\hline Finland & 34252 & 28014 & 23652 & 24629 & 20242 & 4 \\
\hline Norway & 223900 & 271000 & 256800 & 348700 & 362400 & 1 \\
\hline Sweden & 25000 & 28000 & 30000 & 29000 & 30000 & 1 \\
\hline \multicolumn{7}{|l|}{ Primary zinc } \\
\hline Denmark & NO & NO & NO & NO & NO & 1,3 \\
\hline Finland & 43125 & 47716 & 51684 & 49890 & 49403 & 5 \\
\hline Norway & 129300 & 137300 & 143500 & 140900 & 133300 & 1 \\
\hline Sweden & 156334 & 148600 & 185900 & 197000 & 214600 & 1 \\
\hline \multicolumn{7}{|c|}{ Total copper production } \\
\hline Denmark & NO & NO & NO & NO & NO & 1 \\
\hline Finland & 405170 & 391283 & 395884 & 390289 & 392865 & $1,2,4$ \\
\hline Norway & 26700 & 30500 & 35900 & 35600 & 38500 & 1 \\
\hline Sweden & 208000 & 223000 & 215000 & 236000 & 222000 & 1 \\
\hline \multicolumn{7}{|l|}{ Precious metals } \\
\hline Denmark & NO & NO & NO & NO & NO & $1,3,5$ \\
\hline Finland & 28 & 35 & 40 & 39 & 38 & 4 \\
\hline Norway & 1 & 1 & 1 & 1 & 1 & 5 \\
\hline *Sweden & 311 & 325 & 304 & 297 & 4 & 3 \\
\hline
\end{tabular}

NO: Not Occurring

*the data for precious metals includes silver and gold for all years except 2005 , for which year no data on silver production was reported. The figures for silver production data may be overestimated.

References:

1: US Geological survey; http://minerals.usgs.gov/minerals/pubs/country/europe.html

2: VAHTI (data system of the Finnish Environmental Institute)

3: European Association of Mining Industries; http://www.euromines.org/

4: Teknologiateollisuus, Year books 2004 and 2007; www.teknologiateollisuus.fi

5: National expert knowledge

The activity data in the above table summarizes figures for specific production processes depending on the origin of the feed material for the production. Detailed information on primary, secondary and other special production and production processes are given in Annex 2, Table 2.1.

Magnesium production, which was a major source of HCB emission, no longer occurs in the Nordic countries. Secondary production processes, which may be based on new and end-of-life scrap, are more potent sources of UPOP emissions compared with primary production processes. However, changes in the production cycles and improved quality of recycled material indicate a decreasing level of the presence of precursor impurities in recycled metal shredder and scrap material.

Aluminium and copper production are major contributors to potential emissions from the non-ferrous metal industry. 
Copper production is at a higher level in Finland and Sweden compared to Norway. Finland, which has the highest copper production of the Nordic countries, also has highly specialized production processes for different types of feed material (see Annex 2, Table 2.1).

Aluminium production is a major source for Norway, but the source potency in terms of potential HCB emissions is highest from copper production. For PCB the potential emission intensity is comparable (see Annex 2, Table 2.2 and 2.3).

Precious metals include silver and gold. The associated production processes are judged of little importance for the non-ferrous source sector, as the figures for Sweden seems to relate to production capacities and not actual production levels.

Increased emissions from foundries using recycled metals and scrap in multi-melting furnaces may occur, depending on the quality of the input material (Alcock et al., 1999). However, most industrial processes have been updated and new BAT approaches have been implemented to decrease the unintentional emission of HCB and PCB as well as to increase the Destruction and Removal Efficiency (DRE) within all sub-processes, reducing both emission and contamination levels in residue products. The CORINAIR Emission Inventory Guidebook (EMEP, 2006) recommends emission factors for fragmentizing operation facilities (PRTR code $2 \mathrm{c}$ and f) of $0.25 \mathrm{~g} / \mathrm{t}$ recycled ferrous scrap. However, data on export-import in terms of masses are scattered and very uncertain and no estimates of this activity have been included in this study.

Table 9 Ferrous and non-ferrous scrap material flow from the recycling industry in Denmark [tonnes].

\begin{tabular}{lrrrrrrrr}
\hline Year & 1995 & 1996 & 1998 & 2000 & 2002 & 2003 & 2004 & 2005 \\
\hline Denmark* $^{*} 1006000$ & 933000 & 971000 & 1089000 & 718000 & 857000 & 634000 & 475000 \\
\hline
\end{tabular}

*No differentiation between ferrous and non-ferrous metal scrap

Reference: DEPA, 2007

Increased minimization of the environmental impacts of metal recycling driven by the EU (Directive 2002/96/EC) and national waste strategies via new technologies are not addressed any further in this study. Emissions from thermal treatment processes in the pre-processing of metal scrap occur during an integrated process, separating plastics and halogens from the metals scrap; a methodology based on an integrated energy and materials recovery and recycling approach. There are methodologies for WEEE recycling and processes designed for the purpose of meeting the new EU WEEE recycling targets. Of interest in relation to UPOPs in this study is the treatment of halogen-containing compounds in complex fractions of WEEE waste such as scrapped circuit boards in such a way that valuable metals can be recovered with no UPOP emission. In principle, end-of-life electric and electronic equipment and end-of-life vehicles both are sources of emissions of UPOPs due to thermal processes included in 
the separation of halogens, plastics and metals prior to reuse of the metal scrap. Shredder plants for the treatment of end-of-life vehicles are included in the list of sources of UPOPs in the Stockholm Convention, Annex C, Part III and further described in section 2.5.

\subsubsection{The Mineral Industry}

Cement production (PRTR code 3c)

Cement production may represent a source of unintentional emission of HCB/PCB; to some extent dependent on the feed material utilized. However, the DRE is $99-99.9999 \%$, so despite the activity, expressed as the amount of cement produced, is high, the emission factor (to air) is expected to be very low (Karstensen, 2004, 2006 and 2007). A factor influencing the potential unintentional emission is the type of feed material used; e.g. the use of combustion residues such as electrostatic precipitator (ESP) fly ash from combustion of milled coal (Goodarzi, 2006) or other recycling material containing chloride. Still, cement-producing facilities have high quality requirements applying to feed material (Ito et al., 2007; Kikichi et al, 2007) and specified limits for the chloride content of feed material of 0.1 percent dry weight (CemMiljø A/S).

The emission of HCB and PCBs from cement-producing facilities may increase with increasing chlorine content of the feed material if the production process does not include cleaning and filtering activities for the reduction of dioxin emissions (Institut for Miljøvurdering, 2004). Filtering will increase the concentration of HCB and PCBs in solid and liquid residues if present or produced in the production process (cf. section on incineration of municipal solid waste).

The average exhaust-gas volume is $2300 \mathrm{Nm}^{3} /$ ton of clinker. The primary fuels used in the cement industry are coal, petroleum coke, heavy oil and - to a lesser extent - natural gas. The effect on the emissions of PCDD/PCDF, PCB and HCB of increasing the total thermal substitution rates with alternative fuels and raw materials (solvents, animal meal, bleaching earth, rubber, waste oil, paper and film plastics, fly ash and waste wood) is negligible. A recent study indicated no effect from increased substitution and showed concentrations of PCBs and HCB $<4$ $\mathrm{ng} / \mathrm{m}^{3}$ (Karstensen, 2007 in press) or $0.4 \mu \mathrm{g}$ PCB TEQ/ $/ \mathrm{Nm}^{3}$ (Karstensen, 2006; Cement Kilns BAT note, 2006). As part of the general BEP principles it is expected that co-combustion of hazardous waste in cement kilns will increase with time (IPPC, 2007). The worst-case emission scenario from the cement industry in the four Nordic countries has been calculated by assuming that the additional constituents besides clinker in cement corresponds to $10 \%$ of the total cement production given in tonnes; activity data are given in Annex 2.

A study by Abad et al. (2004) does not confirm a proportional relationship between emissions from the cement industry and material used 
for co-combustion (secondary fuel) in addition to fossil fuels as primary fuel. The influence on co-combustion of secondary fuels, ranging from meat meal to used tyres and hazardous waste, was measured and reviewed, and insignificant increases in the emission values that remained below the limit according to the European Union Directive of $0.1 \mathrm{ng}$ I$\mathrm{TEQ} / \mathrm{Nm}^{3}$ were shown, with values ranging from 0.001 to $0.042 \mathrm{ng}$ ITEQ/ $\mathrm{Nm}^{3}$ - however, only PCDD/Fs were included, not PCBs. Ranges in emission factors for the emission of PCB and HCB to air from cocombustion processes in the cement kiln are provided in Table 2.2 of Annex 2.

Table 10 Activity data for potential source within the mineral industry [tonnes]

\begin{tabular}{lrrrrrr}
\hline Year & $\mathbf{2 0 0 1}$ & $\mathbf{2 0 0 2}$ & $\mathbf{2 0 0 3}$ & $\mathbf{2 0 0 4}$ & $\mathbf{2 0 0 5}$ & Reference \\
\hline Cement production & & & & & & \\
Denmark & 2660972 & 2698459 & 2546295 & 2861471 & 2706371 & 5 \\
Finland & 1324705 & 1194676 & 1185886 & 1295058 & 1347007 & 2 \\
Norway & 1870000 & 1850000 & 1860000 & 1870000 & 1900000 & 1 \\
Sweden & 2640600 & 2642000 & 2491000 & 2604700 & 2730700 & 3 \\
Lime production & 105498 & 134647 & 99270 & 90376 & 85078 & 6 \\
Denmark & 2042200 & 2259900 & 1919000 & 1900300 & 1852400 & 4 \\
Finland & 100000 & 100000 & 100000 & 100000 & 100000 & 1 \\
Norway & 550000 & 580000 & 590000 & 590000 & 600000 & 1 \\
Sweden & & & & & & \\
\hline
\end{tabular}

References:

1: US Geological survey; http://minerals.usgs.gov/minerals/pubs/country/europe.html

2: VAHTI (data system of the Finnish Environmental Institute)

3: National expert knowledge

4: Kemia Kemi, 6/2006 p. 67 \& 6/2003 p. 58

5: Figures from the Danish producer, Aalborg Portland Cement

9: Statistics Denmark

Production of cement is at the same level in Denmark and Sweden, while Norway and Finland have slightly lower activity for cement production.

Lime production activity is very high in Finland compared to the remaining Nordic countries. Regarding the figures for lime production from US Geological Survey, these overestimate the Danish figures, while the Finnish production data is significantly underestimated (see Table 2.1 in Annex 2). Despite the uncertainty associated with the activity data, lime production is considered of minor importance to the overall picture for the mineral industry sector, due to the low potency of emissions from this activity (see reported emission factors in Annex 2, Table 2.2 and 2.3).

Glass and glass fibre production (PRTR codes 3e and f)

The furnaces encountered within the glass industry, and within each individual sector, vary considerably in size, throughput, melting technique, design, age, raw material utilized, and the abatement techniques applied. Therefore, considerable variation is apparent in the emissions reported. Chloride may occur as an impurity in input material, and for some production types $\mathrm{NaCl}$ is used as a raw material as well. In processes including 
organic additives as raw materials for pre-processing into blends transferred for melting in furnaces, HCB and PCBs may be de novo synthesized. However, as with any other industrial combustion process, facilities manufacturing glass products are able to decrease emissions by utilizing baghouse filters, electrostatic precipitators (ESPs) or using aqueous media (e.g. a wet scrubber) (IPPC, Reference document on BAT, GL, 2001; Australian Government, 2004).

Low but measurable concentrations of PCB have been detected in a Swedish study on ash samples from a small ceramic facility, while the HCB content of the ash was $53 \mu \mathrm{g} / \mathrm{kg}$ ash (Naturvårdsverket, 2005).

Where wet scrubbing and quick cooling of flue gas for the reduction of dioxin emissions are performed, the wastewater may be a source of release to water, depending on national laws, taxes and off-site treatment procedures (IPPC, BREF, GMI, 2001).

The numbers of installations in the Nordic countries producing mineral wool (PRTR code 3f) are 4, 5, and 5 in Denmark, Finland and Sweden, respectively (the 1996 production level per country being $7-9 \%$ of the total EU production, IPPC, BREF, GMI, 2001). For domestic glass there is 1 installation in Denmark, with 15 in Sweden and at least 4 in Finland. Still, the largest sector is production of container glass. The number of furnaces reported in relation to container glass is 1 installation in each country, and 3, 2 and 2 furnaces in Denmark, Finland and Sweden, respectively; Norway is not included.

Emissions to air may be a problem if e.g. dust is contaminated with UPOPs. Initiatives have been implemented to reduce waste generation and to recycle in-house and post-consumer waste.

Release to the water environment is relatively low, but is not specified according to contamination type.

\section{Ceramics (PRTR code 3g)}

In the reference document for BAT in the Ceramics Manufacturing Industry (IPPC BREF CMI, 2007), emissions of chlorinated organic compounds are not mentioned. Clays containing trace levels of chloride or water containing chloride are possible sources in the manufacturing process from which the occurrence of $\mathrm{HCl}$ may result in the firing process in the flue gases of the kiln. In addition to the organic content of the raw material, thermal process technologies involving fuels like oil, coal and alternative/secondary fuels, which may contain chlorine as well, are part of the production process. Therefore, it seems possible that PCBs and HCB may be emitted during production of e.g. roofing tiles and bricks (PRTR code $3 g$ ). In addition, contamination of process water may occur during the operation of wet off-gas scrubbers. The water added directly to ceramic body mixes subsequently evaporates into the air during the drying and firing stages (IPPC BREF CMI, 2007). Process water from wet scrubbing contains dust that may 
increase the risk of release in effluent water; this is a general phenomenon for flue-gas or off-gas cleaning processes.

To the knowledge of the authors, asbestos (PRTR code $3 d$ ) is not produced in any of the Nordic countries and is judged of minor importance, if any, regarding unintentional emission of HCB and PCBs. Likewise, no activities categorized under PRTR code $a$ and $b$ could be identified as either occurring or relevant sources of UPOPs.

\subsubsection{The Chemical Industry}

As described in the introduction, and as implicit given by the title of this project, HCB and PCBs are not used, produced or imported in any of the Nordic Countries. Still, halogenation is one of the most important and versatile processes in chemistry. Its industrial application is dominated by chlorination, due to the different reactivity and the higher prices attached to bromine, iodine and fluorine.

Organic chemicals industry (PRTR code 4a)

The IPPC reference document on BAT for the production of organic fine chemicals (IPPC BREF OFC, 2006) focuses on the batch manufacture of organic chemicals in multipurpose plants and addresses the manufacture of a wide range of organic chemicals, but evidently not PCB and HCB. Still, chlorinated solvents prepared using modern techniques of purification include HCB impurity levels in the low $\mu \mathrm{g} / \mathrm{kg}$ (parts per billion) range ( $<20$ for trichloroethylene and $<10$ for perchloroethylene). The IPPC reference document includes a sub-chapter on co-incineration of halogenated waste solvents together with exhaust gases from production processes at combustion temperatures of $1100{ }^{\circ} \mathrm{C}$ and with residence times of 2 seconds or higher. Temperature control to prevent de novo formation of PAH, PCB and dioxins, and subsequent flue-gas treatment resulted in emission levels of $0.006 \mu \mathrm{gCB} / \mathrm{m}^{3}$ clean gas, the waste solvent input being low weight aliphatic alcohols and methylene chloride (for details, cf. Table 4.47 in IPPC BREF OFC, 2006).

\section{Large Volume Organic Chemicals Industry (PRTR code 4a)}

The reference document on BAT within the Large Volume Organic Chemicals (LVOC) Industry gives an emission factor for PCBs of $0.1 \mathrm{ng}$ I$\mathrm{TEQ} / \mathrm{Nm}^{3}$ for good operation conditions in process vent (IPPC BREF LVOC, 2003). Furthermore, the document states that 'polychlorinated dibenzodioxins (dioxins), polychlorinated dibenzofurans (furans) and polychlorinated biphenyls (PCBs) may be generated as pollutants from certain production processes that use chlorine'. Dioxins can also be emitted from incinerators treating a chlorinated or non-chlorinated feedstock if improper operating conditions are used'. HCB is mentioned as a water effluent contaminant; a wastewater effluent concentration level of HCB and PeCB 
(Pentachlorobenzene) of $1 \mu \mathrm{g} / \mathrm{l}$ is reported as BAT for effluent where the final treatment is biological treatment (IPPC BREF LVOC, 2003). Effluent concentrations in wastewater from the chemical sector as well as waste gas emissions depend on the degree of technology implemented for the reduction of these emissions (cf. IPPC BREF CWW, 2003).

According to the Corinair Emission Inventory Guidebook (EEA, 2006), default emission factors to use when estimating the emission of HCB from the production and use of chlorinated organic solvent are in the range of 2 to $10 \mathrm{~g} / \mathrm{t}$ for production of the solvents tetrachloromethane, trichloroethylene and tetrachloroethylene (Duiser and Veldt 1989). A default emission factor for unspecified chlorinated solvent production and use is $2 \mathrm{mg} / \mathrm{t}$ (EEA, 2006).

\section{Production of fertilizers (PRTR 4c)}

Some chlorine-containing pesticides may contain impurities of HCB as this compound is formed as a by-product during the production of e.g. Lindane, Dacthal (DCPA), Pentachlorophenol, Atrazine, Simazine, Picloram, Pentachloronitrobenzene (PCNB, quintozene), Chlorothalonil, Endosulfan and Clopyralid (see Annex 3).

Information from Cheminova's homepage indicates that chlorpyriphos is produced in Denmark under the trade name Cyren ${ }^{\circledR} / \mathrm{Nufos}{ }^{\circledR}$ (chlorpyrifos) ${ }^{1}$. It is not known to the authors whether chlorinated pesticides are produced in Finland or Norway. No pesticides are produced in Sweden (Naturvårdsverket, 2005).

The use of pesticides known to include HCB impurities, and therefore representing a potential source to unintentional HCB emission, is prohibited in Denmark (DEPA, 2007). Of the above mentioned HCB-containing pesticides, chlorpyriphos is included in the Finnish sales statistics from $2006^{2}$. None of the HCB-containing pesticides are in use in Sweden (Naturvårdsverket, 2005). Activity data on the production of pesticides are not available, but use-data for Finland are included as a diffuse source (see Table 18) and in Annex 3.

Inorganic chemicals industry (PRTR code b)

The IPPC reference document on production of special inorganic chemicals (IPPC BREF SIC, 2007) includes one activity that may result in unintentional emission of PCB, i.e. the utilization of industrial waste, and especially petrochemical residues, for power generation. This type of increased optimization of the use of biological energy resources, e.g. waste-to-energy approach, is based on highly developed technological processes, such as dry flue-gas treatment, to eliminate any wastewater contamination, and multiple-step combustion chambers to increase the

\footnotetext{
${ }^{1}$ http://www.cheminova.dk/dk/produkter_02/cyren/20021010_01.htm

${ }^{2}$ http://www.evira.fi/attachments/kasvintuotanto_ja_rehut/kasvinsuojeluaineet/tilastot/2006/ myynti_rk_2006.pdf
} 
reduction and destruction efficiency at the same time as energy production (IPPC BREF SIC, 2007).

Denmark has no chlor-alkali plants for the production of chlorine, sodium or potassium hydroxide, while Sweden, Norway and Finland produce chlorine with decreasing capacity from 2000 and forward according to European statistics (IPPC BREF CAMI, 2001).

No information about the emission potential is given in the IPPC BREF document for the Chlor-Alkali Manufacturing Industry and this activity has not been included in the emission estimates. However, chlorine is used for synthesis of e.g. organic chlorinated solvents, and this production is included in the inventory as mentioned below (IPPC BREF CAMI, 2001).

The Finnish HCB inventory includes the production of potassium sulphate as the most important source of unintentional emissions of HCB in Finland (Saarinen et al., 2007). No attempt has been made to investigate the specific production processes other than the ones that are included in the BAT reference documents (BREFs) under the IPPC Directive and according to point source sectors as defined in Table 3 . An overview of sources of UPOPs in Sweden may be found in the report from Naturvårdsverket published in 2005, although data gaps are present. The available information is provided below.

Table 11 Activity data for solvent production within the Chemical industry [tonnes]

\begin{tabular}{|c|c|c|c|c|c|c|c|c|}
\hline Year & 1999 & 2000 & 2001 & 2002 & 2003 & 2004 & 2005 & Reference \\
\hline \multicolumn{9}{|c|}{ Organic Chemicals production } \\
\hline \multicolumn{9}{|c|}{ Chlorinated solvent production } \\
\hline Denmark & 63 & 9 & 0 & 4,068 & 804 & NR & NR & 1 \\
\hline Finland & 0 & 0 & 0 & 0 & 0 & 0 & 0 & 2 \\
\hline Norway & NR & NR & NR & NR & NR & NR & NR & \\
\hline Sweden & NR & NR & NR & NR & NR & NR & NR & \\
\hline \multicolumn{9}{|c|}{ Inorganic Chemicals production } \\
\hline \multicolumn{9}{|c|}{ Potassium sulphate } \\
\hline Denmark & NR & NR & NR & NR & NR & NR & NR & \\
\hline Finland & NR & NR & 178685 & 195841 & 172771 & 196163 & NR & 2 \\
\hline Norway & NR & NR & NR & NR & NR & NR & NR & \\
\hline Sweden & NR & NR & NR & NR & NR & NR & NR & \\
\hline
\end{tabular}

NR: Not Reported

References:

1: Statistics Denmark

2: Saarinen et al., 2007

Data on production and uses in the Nordic countries is very limited and scattered data and data gaps clearly exist (e.g. Naturvårdsverket, 2005). Therefore estimated emissions from the chemical industry are not consistent and comparable between countries and may not be representative of the current situation. Available emissions factors for HCB are given in Annex 3 and estimated emissions in Chapter 3. As a result of the clean production action (Clean Production Action, 2006) it is suspected that 
production volumes are on the decrease. Information on Swedish production of vinyl chloride exists, but no activity data was available (Naturvårdsverket, 2005).

\subsubsection{Waste and waste management}

The IPPC reference document on BAT for the waste treatment industries (IPPC BREF WTI, 2006) is of relevance for industrial activities related to recovery and disposal of hazardous and non-hazardous waste. As such the information included regarding processes and sources of HCB and PCB off-site transfers of waste concerns all sectors, with the metal industry being a major contributor (see section 2.1.2 and below). Potential emissions relating to the waste industries are emissions and consumption from: common waste treatment processes/activities, biological treatment processes, physico-chemical treatment processes, waste treatments applied mainly to recover materials from waste, waste treatments aimed to produce a material to be used as fuel. In general, regulatory drivers for lowering the amount of waste produced, and increasing the return and investment regarding technologies for the recovery of materials and energy (e.g. PRTR code $1 b$; waste to energy technologies) from waste may result in an increased number of dedicated plants and i.e. treatment technologies for specific types of waste as described below. At the present stage such activities are largely unquantifiable.

Installations for disposal or recovery of hazardous waste (PRTR code 5a) Waste oil refining /treatment plants

The reference document includes emissions of PCB from re-refining of oils (R9, as defined in Directive 75/442/EEC which refers to the IPPC Directive, changed according to the Commission Decision 96/350/EC). According to the IPPC BAT on waste incineration, re-refining waste oil installations operating in the EU show stack gas emissions of PCB at the level of $0.8 \mathrm{~kg} /$ year, effluent concentration of PCB in wastewater below $0.001 \mathrm{mg} / \mathrm{L}$ and PCB captured in solid particulates from filters (IPPC BAT on WTI, 2006)

According to Statistics Denmark, activity data for the production and use of waste oils including PCBs, polychlorinated terphenyls (PCT) or polybrominated biphenyls (PBBs) are around 11 tonnes produced and used waste oil, respectively. Waste oils are assumed to be included in the statistics on hazardous waste. No effort has been made to obtain information on the number of waste oil refining plants, if any, in the Nordic countries. According to the information from the Danish waste statistics, imported waste for energy production purposes may include fractions of waste oils. 
PCB air emission factor from off-gas thermal destruction plants from waste oil treatment plants is $1 \mathrm{ng} / \mathrm{Nm}^{3}$ according to the BAT document on waste treatment technologies (IPPC BAT on WTI, 2006)

Shredder plants for the treatment of end of life vehicles

Most vehicles and vessels contain large amounts of hazardous materials, such as asbestos (in particular if built before the 1980s), oils and oil sludge, PCBs (polychlorinated biphenyls), and heavy metals in paints and equipment. Before adoption of the part of the Basel convention dealing with hazardous waste, ship dismantling represented one of the major streams of hazardous waste from industrialized countries to the developing world. In 2004 a study for the Commission (DG TREN) estimated that oil sludge from end-of-life ships alone will total between 400,000 and 1.3 million tonnes per year by 2015. Of the hazardous waste in dismantling facilities every year, asbestos will amount to 1,000-3,000 tonnes, TBT 170-540 tonnes and environmentally harmful paints 6,00020,000 tonnes (PRTR code Xx). The WEEE directive was adopted in Denmark in 2005 (Statutory Order on Waste, no. 619 of 27 June 2000).

PCB tests of disposed shredder residues (SR) generated by several Californian facilities average total levels ranging from 16 to $82 \mathrm{ppm}$ (Schwarzenegger and Gorsen, 2006); the $50 \mathrm{ppm}$ limit triggering requirements for hazardous waste management of SR and e.g. if the SR are to be landfilled or managed at special facilities (cf. Table 2). Reported release factors for PCB from shredder plants into waste is $0.3 \mathrm{mg} / \mathrm{t}$ which means that it is not to be classified as hazardous waste and may well be deposited as landfill in Denmark and pre-processed prior to further reuse in e.g. cement production processes. The emission factor for PCB emissions from shredder plant processes to air is reported to be $5.2 \mathrm{mg} / \mathrm{t} \mathrm{(Bi-}$ PRO, 2006). Comparison of the release factor into waste streams and emission factors to air, respectively, suggests that emission to air is the major pathway for UPOPs.

Recovery and disposal of auto shredder residue or auto fluff

According to Nourreddine (2007), about $75 \%$ of the total weight of endof-life vehicles (ELVs) is recycled in EU countries. The remaining 25\%, auto shredder residues (ASR) or auto fluff, is disposed as landfill. The quantities of shredder fluff are likely to increase in coming years. This is because of the growing number of cars being scrapped, coupled with the increase in the amount of plastics used in cars.

The goal of the European ELV Directive is for max. 15\% of the vehicle's weight to be disposed of at landfill sites, decreasing to $5 \%$ by 2015 . The draft directive states that a further $10 \%$ can be incinerated (Nourreddine, 2007). Therefore, ASR is treated for the purpose of material recycling and energy recovery. In Denmark, special focus is on the change from landfill to reuse of foundry and shredder waste (DEPA, 2006); i.e. 
pre-processing and reuse as input material in the metals industry. Most of the Danish metal shredder residue is exported.

Recycling of scrap and shredder

Residues characterized as recycling material or non-hazardous waste may be exported and imported for further processing and reuse (Regulation (EC) No. 1013/2006 of the European Parliament and of the Council) ${ }^{3}$. This makes it even more difficult to give an estimate of potential sources and emissions relating to solid residues. Within the recycling industry, there are companies which specialize in the pre-treatment of e.g. metal shredder residues to meet the quality requirements for re-entering metal production processes.

Incineration of hazardous waste (PRTR code 5a)

The IPPC Reference Document on BAT for the manufacture of organic fine chemicals gives emission levels of 0.002 to $0.02 \mu \mathrm{g} / \mathrm{m}^{3}$ for coincineration of halogenated waste solvents together with exhaust gases from production processes (IPPC, OFC, 2006).

In comparison the maximum emission from co-combustion processes with use of different types of hazardous waste in the cement production is $0.004 \mu \mathrm{g} / \mathrm{m}^{3}$.

Feed material for combustion processes

Investigation of thermal treatment of ASR and RDF (Gendebien et al., 2003), respectively, have shown that combustion of ASR results in the production of more and higher chlorinated PCBs in the primary combustion phase compared to combustion using RDF as input material. This might be attributed to the effect of the abundance of chlorine, $\mathrm{Cu}$ and $\mathrm{Fe}$ metal in the input material on the unintentional formation of PCB as a byproduct. The PCB formed in the primary combustion chamber was largely decomposed by the secondary combustion, and almost all PCB was removed by filtering and the activated carbon adsorption. The rates were $99.1 \%$ and $99.9 \%$ with the incineration of RDF or ASR, respectively (Ishikawa et al, 2007).

Incineration of non-hazardous waste (PRTR code 5b)

Burning of organic matter in the presence of chlorine is one of the main causes of formation of a range of organic pollutants, including dioxins, PCBs and HCB. The high temperatures that arise in a waste incinerator, for example, result in the pollutants in the material breaking down. However, when the flue gases are cooled, conditions arise which result in de novo formation of these substances. Not only the process parameters of incineration but also the chlorine content and waste composition influence the potential for de novo formation of UPOPs (e.g. Jacquinot et al.,

\footnotetext{
${ }^{3}$ http://trade.ec.europa.eu/doclib/docs/2007/july/tradoc_135378.pdf
} 
2000; Zevenhoven and Kilpinen, 2001). The contribution to PCB emissions depends largely on the type of wastes and incineration technology utilized. Incineration of PCBs and chlorine-containing wastes has the highest PCB emission factors.

Studies of non-optimal combustion conditions during waste incineration (Blumenstock et al., 2000) have shown that POP emission favours unintentional formation of lower chlorinated dioxins, furans and PAHs, while the formation of $\mathrm{HCB}$, PCBs and the higher chlorinated dioxins seems unaffected or even to decrease under non-optimal combustion. Therefore, the emission of PCBs seems to be unaffected by non-optimal conditions, e.g. lower temperatures, during waste incineration to the same degree as higher chlorinated dioxins. The IPPC reference document on BAT for waste incineration provides an emission factor value ranging from $<1 \mu \mathrm{g} / \mathrm{Nm}^{3}$ to $<2 \mathrm{ng} / \mathrm{Nm}^{3}$ (IPPC, WI, 2006). As data on incineration stack gases per year are not available, the emission factors presented and explained in Annex 3 have been used.

Besides the waste amounts in absolute numbers, the content of the waste in terms of precursors, such as plastics and certain metals, are of importance for the size of the emission factor. There are many ways of presenting waste categories and fractions within and between sectors, evident from an examination of the national waste statistics for the Nordic countries, and at EU level (see references to Table 4.1 in Annex 4). The newest approach is described in the new EU guidelines for reporting waste statistics. The categorization of waste into different categories is therefore not strictly harmonized between the countries and accordingly differences are apparent in the waste statistics categories (Statistics Denmark, Finland, Norway and Sweden). Some statistics are based on final disposal categories and statistics within sectors, some for households only and some include cross-sectoral waste fractions summed up into e.g. hazardous waste. At the same time, similar to the new E-PRTR register and underlying regulations, a relatively new way of registering waste statistics may influence national waste statistics in the future (Regulation No 1379/2007/EC). Furthermore, in the statistics published at sector level, e.g. the Swedish waste management report (RVF, 2006), the figures may differ from figures produced under reporting obligations to the EU (Swedish EPA, 2006). No in-depth comparative analysis of reports and differences in the reporting of waste statistics has been performed.

Another aspect worthy of note is that waste characteristics continually change due to e.g. increased sorting, recycling and reuse of various materials. This may have influenced the composition of MSW sent to combustion in terms of e.g. lower chlorine content. These aspects together with technological developments and optimization of the combustion processes mean that the reported emissions factors probably are probably exaggerated. 
Aggregated figures for the waste categories reported in Table 4.1 in Annex 4 are show in Table 12. Waste categories have been grouped into municipal waste and 'hazardous waste'; the latter group including all other reported waste categories besides domestic or municipal waste.

Table 12 2004/2005 activity data for incineration; feed material divided into 'hazardous' and municipal waste, respectively [tonnes]

\begin{tabular}{lrrr}
\hline & 'Hazardous' waste & Municipal waste & Reference \\
\hline Denmark & 86490 & 1468500 & 1 \\
Finland & 271829 & 239924 & 2 \\
Norway & 574246 & 226843 & 3 \\
Sweden & 1440640 & 1944290 & 4 \\
\hline
\end{tabular}

References:

1: DEPA, 2007

2: Finnish waste statistics and expert judgement

3: Norwegian waste statistics and expert judgement

4. Statistics Sweden

Details regarding waste categorization are provided in Annex 4. The waste amounts reported as 'hazardous' waste in Table 12 do not refer to the definition according to the Basel Convention (releases into solid residues $>50 \mathrm{mg} / \mathrm{kg}$ for both PCB and HCB), but mostly to industrial waste and wastes other than household waste (see Annex 4, Table 4.1 and e.g. DEPA, 2006).

According to European and national waste strategies corresponding Recovery and Disposal codes for different waste types have been developed; e.g. Regulation (EC) No 1379/2007 (COM, 2007c). The methodologies for reporting waste amounts according to type as well as the number of subcategories within each type of waste differ between sector reports, national statistics and EU reporting Recovery and Disposal categories (see e.g. COM, 2006 and 2007b and c). Is has not been possible to perform an in-depth analysis of the reasons behind the inconsistencies between the different reporting formats. Details regarding the raw data behind the figures given in Table 12 may be found in Annex 4, and possible explanations for the high variation in waste amounts between countries are given in Chapter 3.

Input material or feed material

The cornerstones of the EU strategy to manage waste are to prevent waste in the first place, recycle waste, turn waste into a $\mathrm{CO}_{2}$-neutral energy source and optimize the final disposal of waste, including its transport. In this respect the fraction of plastics in waste for combustion is to be minimized. In the EU, municipal waste is by far the largest source of plastic waste with plastic comprising more than $60 \%$ of the total. An overview of the chlorine content of different types of plastics is provided in Kikichi et al., 2007, while an overview of the chlorine content in different waste types is given in Annex 5. PVC is a source of chlorine in the waste, but 
under optimal combustion conditions is not necessarily a source to the emission of PCBs (e.g. Jacquinot et al., 2000).

Reported PCB levels in different types of waste are as follows: 0.2 to $0.4 \mathrm{mg}$ PCB / kg dry weight municipal waste, up to $60 \%$ dry weight hazardous waste and 0.01 to $0.13 \mathrm{mg}$ PCB / kg dry sewage waste (IPPC BRF WI, 2006). None of the waste categories reported in Annex 4, or i.e. in Table 12, are expected to be contaminated to a higher level than the maximum of $0.13 \mathrm{mg} / \mathrm{PCB} / \mathrm{kg}$ dry weight waste. Other chlorine release, or even small amounts of PCB-containing waste, may arise from different types of refuse derived fuel (Gendebien et al., 2003). Depositing of organic and burnable waste at landfill sites is declining, and thereby this source of accidental leakage into the underlying soil and groundwater is reduced. Final disposal of the waste may occur in the form of combustion residues as described below.

The PCB concentration levels in sewage sludge from different sewage treatment plants are between 0.08 and $0.187 \mathrm{mg} / \mathrm{kg}$ dry matter, the limit for co-combustion being $0.2 \mathrm{mg} / \mathrm{kg}$ dry weight (IPPC BREF LCP, 2006). The amounts of sewage sludge disposed for combustion are included in the category municipal waste in Table 12 . The amounts are however small and have been replaced by composting; in Denmark high quality sewage sludge is processed by storage at landfill sites combined with garden waste.

Output or Residual material from combustion

Regarding final disposal, the Basel Convention includes characterization categories of waste of which some are specifically related to the handling of PCB- and/or HCB-contaminated end-products and wastes. Specific waste characterization categories of Annex 1 (-to be controlled) and II (requiring special consideration) of the Basel Convention of relevance for an HCB and PCB emission inventory are: Annex I category Y10: Waste substances and articles containing or contaminated with polychlorinated biphenyls (PCBs) and/or polychlorinated terphenyls (PCTs) and/or polybrominated biphenyls (PBBs) and Annex II category Y46: Wastes collected from households and Y47 Residues arising from the incineration of household wastes. 
Table 13 Reported residues from combustion [tonnes]

\begin{tabular}{llrrrrrr}
\hline Year & & 2002 & 2003 & 2004 & 2005 & 2006 & Reference \\
\hline Sweden & Slag, from MSW combustion & 395500 & 446500 & 485000 & 550850 & 598545 & 1 \\
Denmark & Slag, from combustion in total & 543254 & & 564313 & 595272 & & 2 \\
Sweden & $\begin{array}{l}\text { Flue-gas cleaning residues, } \\
\text { from MSW combustion }\end{array}$ & 109900 & 149300 & 138000 & 160920 & 176298 & 1 \\
Denmark & $\begin{array}{l}\text { Flue-gas cleaning residues, } \\
\text { from combustion in total }\end{array}$ & 581000 & 691000 & 615000 & 642000 & NR & 2 \\
\hline
\end{tabular}

References:

1: Svensk Affaldshåndtering 2007

2: Affaldsstatistik 2005, DEPA, 2006

From Table 13, a significant increase in the amounts of residue from combustion may be observed. This is an expected general trend for the Nordic countries due to the common goals of the national waste strategies of decreasing the amount of organic, $\mathrm{CO}_{2}$-neutral, amounts of waste deposited as landfill.

According to guidance document of best available technologies under the Stockholm Convention, the amounts of combustion residues produced from MSW are as follows: $200 \mathrm{~kg}$ slag or bottom ash per tonne MSW, 3 $\mathrm{kg}$ boiler ash per tonne MSW, $10 \mathrm{~kg}$ filter ash or fly ash per tonne MSW. The amount of residues collected by ESP or FF combined with wet and dry scrubbing are 12 and $30 \mathrm{~kg}$ per tonne MSW, respectively (Vehlow et al, 2006; BATBEP guidelines, 2006).

Based on the MSW figures in Table 12, the combustion residues have been calculated and listed in Table 14. Estimated combustion residue amounts in Table 14 may be compared to the reported amounts in Table 13 for evaluation of uncertainties.

Table 14 Estimated amounts of combustion residues, in tonnes, produced in 2004/2005 [tonnes].

\begin{tabular}{lrrr}
\hline & MSW & Slag & Flue-gas cleaning residues \\
\hline Denmark & 1468500 & 256988 & 10280 \\
Finland & 239924 & 41987 & 1679 \\
Norway & 226843 & 39698 & 1588 \\
Sweden & 1944290 & 340251 & 13610 \\
\hline
\end{tabular}

The amounts of slag and flue-gas cleaning residues produced respectively are $15-20 \%$ and 3-5\% of the MSW input material according to the Danish and Swedish waste statistics (DEPA, 2006; RTF, 2006). The figures in Table 14 underestimate the reported residues in Table 13, a possible explanation for which being waste imported for the purpose of producing energy. There may be uncertainty with regard to the estimated amount of MSW with combustion as a final disposal category; e.g. the MSW data for Sweden may very well be underestimated (RTF, 2006). 
Combustion residues from MSW incineration (Waste category Y47, Annex I of the Basel Convention)

PCBs and HCB are formed especially in municipal solid waste incineration. It is expected that the PCB level in bottom ashes from well-operated plants incinerating municipal solid waste is kept below $10 \mathrm{ng} / \mathrm{g}$. The most frequent filter installed in waste incineration plants is the electrostatic precipitator (ESP). Fabric filters (FF) are mainly used if dry or semi-dry scrubbing is applied. According to a review by Vehlow et al., 2006 there are no significant differences between PCB concentrations in the combustion residue materials collected in ESP and FF. Concentration ranges from 1990 onward are from $<1$ to $110 \mathrm{ng} / \mathrm{g}$. This means that for welloperated waste incineration plants a concentration in combustion residues below the upper limit of PCB concentrations of $50 \mu \mathrm{g} / \mathrm{kg}$ is realistic (Vehlow et al., 2006). Examples of annual PCB releases into combustion residues for 2004/2005 are given in Table 15.

Table 15 Estimated PCB content in combustion residues [kg/yr]

\begin{tabular}{lrr}
\hline & slag & Flue-gas cleaning residues \\
\hline Denmark & 12849 & 103 \\
Finland & 2099 & 17 \\
Norway & 1985 & 16 \\
Sweden & 17013 & 136 \\
\hline
\end{tabular}

These figures are highly uncertain. Estimates are based on the combustion residues in Table 14, which are significantly underestimated. On the other hand, maximum measured PCB concentrations in combustion residues (Vehlow et al., 2006) have been used for deriving the release into waste figures in Table15.

In the waste statistics from 2005, the Danish EPA states that the prohibition of combusting electric and electronic waste, non-reusable PVC and impregnated wood waste is argued to result in a significant reduction of heavy metals in the slag, whereas the influence on the amounts of UPOPs in the residue is not mentioned.

Taking into account the uncertainty, and that the estimated figures are indicative examples for deriving releases into waste streams and/or residue products, the figures still indicates a PCB release above $500 \mathrm{~kg} / \mathrm{yr}$, classifying this material stream as very important (BiPRO, 2006).

Based on the above estimated PCB content of slag, re-combustion at high temperatures should be performed to secure a high DRE \% prior to recycling. In Denmark the 2008 goal of reusing 85\% of the slag was reached in 2005 (Danish Government, 2005; DEPA, 2006).

Landfill (PRTR code 5d)

Drivers for changes in the composition of waste disposed of at landfill sites are e.g. the Waste Landfill Directive (1999) that bans the land filling 
of tyres by 2006; the End of Life Vehicle Directive (2000) that stipulates the separate collection of tyres from vehicle dismantlers and encourages the recycling of tyres (Aylon et al., 2007). The current main routes for the management of waste tyres in Europe are landfill (40\%), energy recovery (20\%), material recycling (18\%), rethreading (11\%) and export (11\%) (European Tyre Recycling Association, http://www.etra-eu.org/). Nonmetallic parts from sorting of electric and electronic scrap (e.g. Maag and Lassen, 2000) and shredder plants (PRTR code $2 f$ or $5 a$ ) are to be treated as hazardous waste, not to be incinerated but sent to landfill.

Other drivers are the national waste strategies and associated goals for recycling and reuse of residual products such as e.g. sewage sludge, municipal waste and hazardous waste. Problematic waste like PVC is to be recycled or deposited as landfill.

Potential sources from landfill sites depend on the waste types and mixtures present. Another important factor for this source is the use of sealant, the presence of a gas collection system. Sealant may inhibit the emission from landfills, but still the municipal wastes determine the maximum methane conversion factor and increased methane emissions increase the potential for PCB emissions. Figures in the Corinair guidebook range from 0.19 to $0.3 \mu \mathrm{g} \mathrm{PCB} / \mathrm{m}^{3} \mathrm{CH}_{4}$ (EEA, 2006). In the USA PCB emission inventory an emission factor for PCB emission to air from landfill is $4.3 \mathrm{~kg} / \mathrm{t}$ PCB containing waste. The level of PCB emission from landfill highly depends on the type of PCB wastes and, to a lesser extent, on the content of PCB in the wastes. An investigation by Persson et al. (2005) showed that emission flux of PCBs from landfill which contains 10-18 tonnes PCBs in polysulphide sealant is only about $1 \mathrm{~g} \Sigma$ $\mathrm{PCB} / \mathrm{yr}$.

National waste strategies for the Nordic countries all comply with the EU waste strategy of increasing reuse and recycling, with disposal at landfill only as a final solution. Landfill will be used as a temporary storage and treatment system prior to final disposal for incineration, composting or reuse in production processes within the energy or industry sectors.

In Denmark a new database for registering activity and quality parameters for landfill sites has been developed (www.erisda.dk). However, this database is still in a developmental phase and may be used in the future for estimating fugitive emissions as well as default runoff parameters according to expected future guidelines on this theme. Future landfill sites are expected to form an integrated part of the sorting, reuse and recycling strategy and therefore maybe more correctly defined as temporary storage systems for pre-processing of material for reuse or recycling in the energy and industrial sectors.

Solid residues from e.g. the energy sector, industrial activities, e.g. slag for asphalt production, and combustion residues that are disposed of at landfill sites may result in leakages from these sites, even though contamination levels may be low. 
Leakages from landfill and resulting soil and water contamination may be of lesser concern than emission to air, as HCB is relatively immobile in soil and modern landfills are designed to capture leachates (DEFRA, 2006). PCBs as well as HCB may eventually leach into the groundwater from contaminated soils, e.g. at old landfill sites, but the magnitude of such sources is highly uncertain.

Increased recycling and decreased solid residues for disposal at landfills UNEP reports that $30 \%$ of the European dust from cement kilns is disposed of as landfill ${ }^{4}$, which implies the importance of high DRE percentages for the prevention of continuous recycling of UPOPs into the production cycle.

Asphalt production at European level also includes high material recycling rates and the need for high DRE of UPOPs in the recycling industries delivering the feed materials for reuse in energy and industry sectors. The production of asphalt is not included in the Finnish IIR (Saarinen et al., 2007). Industrial facilities for producing asphalt (SNAP code: 030313 Asphalt concrete plants and PRTR code 3; 40611: Road paving with asphalt and PRTR code 3f; 060310: Asphalt blowing) may be of relevance for future PCB and HCB inventories; and may also be of relevance for releases to soil.

Wastewater treatment plants (PRTR code 5f)

Sewage treatment processes

The emission of PCB from anaerobic digestion plants is reported at a level of $0.00073 \mathrm{~g} /$ tonne of waste (IPPC, BAT for WT, 2006). For plants including anaerobic treatment, fugitive emissions may contain PCBs of $730 \mu \mathrm{g} /$ tonne waste. Overall, the emissions of HCB and PCBs to surface waters are expected to be very low. This is due to the technological upgrading of WWTPs and the stricter quality requirements in the industry.

Sewage sludge

PCBs and HCB may be present in sewage sludge due to their persistent nature, and may occur in significant quantities. The PCB concentration level in sewage sludge from different sewage treatment plants are reported to be between 0.08 and $0.187 \mathrm{mg} / \mathrm{kg}$ dry matter (IPPC BREF LCP, 2006). The IPPC Reference Document on Waste Treatment, sewage sludge from physico-chemical treatment of wastewaters (IPPC, BAT on WT, 2006) realistically includes PCBs (sum of 6) at a concentration level of maximum $0.12 \mathrm{mg} / \mathrm{kg}$. This is in agreement with measurements of PCBs in Danish sewage sludge including both HCB and PCB at the levels of $0.005-0.12$ and $0.0078-0.017 \mathrm{mg} / \mathrm{kg}$ dry weight, respectively (http://www.aaa.dk/aaa/basis-2004-slam-spildevand.pdf). The Danish sewage waste from municipal wastewater treatment plants includes on

\footnotetext{
${ }^{4}$ http://www.chem.unep.ch/pops/pcb_activities/PCB_proceeding/pcb_proceeding.htm
} 
average a 40\% contribution from industries (Thomsen and Lyck, 2005), which may result in higher variation in the PCB and HCB content. Sewage sludge increasingly is composted at storage basins at landfill sites in combination with garden waste. Depending on the quality of the endproduct, the compost is either combusted, used in e.g. park areas or as compost for private use. Some of the composted material may also be used as fertiliser in the agricultural sector (Directive 86/278EEC). Not all the PCBs spread on land will volatilize but the potential for emission to air is greater than that from landfill. The emission estimate for sludge comprises only $1 \%$ of the total and is highly uncertain. The fraction of sludge that, due to quality requirements, is combusted (cf. Table 3.1, Annex 3) may contribute to the PCB emission from waste incineration and refuse-derived fuel production due to the PCB content of the waste (UK IIR, 2006).

Industrial wastewater treatment plants (PRTR code 5g)

HCB has been detected in treated wastewater from non-ferrous metal manufacturing in the USA and it seems likely that discharges to water from the metal, mineral and chemical industry may occur. In general, it is expected that stricter quality requirements for effective detoxification and treatment processes prior to direct outlet or coupling to the municipal sewer systems have minimized releases to water.

In Denmark, around $40 \%$ of industrial wastewater is received and treated at centralized municipal wastewater treatment plants (Thomsen and Lyck, 2005). There is only few measurement reporting results above the limit of detection for effluent from separate industries in Denmark. Therefore, wastewater effluent is considered of little or no importance regarding the release of PCB and HCB to surface waters for all the Nordic countries due to improved wastewater treatment technologies and quality requirements for pollutants in the effluent water according to the Water Framework Directive. Still, data are scattered and e.g. Nerpin et al. (2005) report PCB as a general contaminant of industrial and household effluents, identified as raised PCB concentrations in sediments close to industrial wastewater point sources. Below the origin of some potential sources to PCB and HCB in urban waste water, and as results thereof in sludge, is listed:

Origin of some potential releases into sewers

Point sources:

- Industrial process wastewater from wet flue gas cleaning and other water containing liquid combustion wastes

- Leachate water from landfill sites

- Water-containing liquid waste from oil regeneration

- Atmospheric deposition from waste incineration 
Diffuse sources:

- Background inputs to the sewer from normal dietary sources

- Background inputs by atmospheric deposition due to contemporary remobilisation/volatilisation from soil and cycling in the environment

- Atmospheric deposition from domestic combustion of coal

- The extent of biodegradation of organic contaminants during sludge treatment

It is judged that the above mentioned sources are of minor importance, even though information indicates that there is still existing diffuse sources contributing to the influent concentration of PCB other than surface run-off into the sewer system (e.g. Almqvist and Hanæus, 2006).

According to a Swedish survey (Naturvårdsverket, 2005), large volumes of air are supplied to the aeration tanks at WWTPs, and from here PCBs especially are emitted, along with small quantities of dioxins and HCB. Release with wastewater effluents as well as trace levels of PCB and HCB in sludge is further discussed in Chapter 2.2 and 3.

\subsubsection{Paper and wood production and processing}

Industrial plants for the production of pulp (PRTR code 6a)

According to the guidelines on best available techniques and provisional guidance on best environmental practices relevant to Article 5 and Annex $\mathrm{C}$ of the Stockholm Convention on Persistent Organic Pollutants (Guidelines on BAT and Guidance on BEP, 2006), HCB and PCBs are not formed during pulp bleaching.

Paper production from use of recycled fibre processes (PRTR code 6b)

Due to the success of the promotion of recycling paper systems in Europe, a corresponding increase in recycling fibre processes (RCF) within the paper industry can be observed; one main category, de-inking, being a source of the emission of PCB. Processes with mechanical and chemical unit processes, i.e. with de-inking, comprise products such as newsprint, tissue, printing and copy paper, magazine paper, some grades of cardboard or market de-inked pulp. The reported content of PCB in RCF sludge, based on German and Dutch studies, ise 95 and $<300 \mu \mathrm{g} / \mathrm{kg}$ dry solid RCF sludge (IPPC, BREF PPI, 2001). It has not been possible to derive activity data of relevance for the process specific sector source of PCB emission.

Wood preservation using pentachlorophenol (PRTR code 6c)

Pentachlorophenol (PCP), by its chemical structure, is a close surrogate of HCB. PCP is derived from HCB by substituting one of HCBs six chloro-substituents with a hydroxyl group. Given its chemical similarity to HCB and that its manufacturing ingredients contain the precursors for 
chlorinated aromatic compounds, the manufacture of PCP often results in the incidental manufacture of both HCB and dioxins/furans. Hence, dioxins/furans and HCB are present in PCP formulations used for wood preservation and may be released, disposed of or transferred for recycling. Production of PCP is included in the emissions from the Chemical Industry, while impregnated wood may be a source of diffuse emission as well as UPOP emission when used as feed material for combustion (cf. Table 4.1, Annex 4).

\subsubsection{Animal and vegetable products from the food and beverage sector}

The chlorine in the salt in carcasses means there is a potential for dioxin formation. Therefore the incineration of animal carcasses and animal meal are performed with the risk of PCB formation depending of the technique used to operate the incinerator (PRTR code $5 e$ or $8 a$ ). The production of fish oil includes a purification step that results in the production of solid carbon filter material that is disposed of as hazardous waste for incineration (IPPC BREF SABI, 2005).

The emission of PCB from waterproof floorings in slaughterhouses during washing/cleaning of the water may realistically result in PCBcontaminated wastewater effluents to surface waters.

\subsubsection{Other}

Textile Industry (PRTR code9a)

The use of organic solvents in the textile industry may result in emissions from thermal processes and specific activities such as dry-cleaning of textiles. In addition, the reference document on BAT in the textile industry (IPPC BREF TI, 2003) recommends to 'avoid emissions of dioxins and furans arising from organically bound chlorine from pesticides potentially contained in the sludge' in relation to sludge disposal from wastewater treatment of wool scouring effluent.

Installation for the building and painting or paint removal from ships (PRTR code 9e)

This source is relevant, but not judged of importance in the long term or at present. No efforts towards quantification of this industrial process have taken place. There are many companies that have specialized competencies in the treatment of different types waste prior to recycling or final disposal by means of deposition at landfill or combustion. 


\subsection{Diffuse sources}

According to the E-PRTR Regulation, diffuse sources are 'the many smaller or scattered sources from which pollutants may be released to land, air or water, whose combined impact on those media may be significant and for which it is impractical to collect reports from each individual source'.

A list of diffuse source ${ }^{5}$ categories as well as the associated definitions may be found in the European PRTR Regulation, Art 2 (12). A description of each source category may be found on the BiPRO webpage on diffuse sources which was created as part of the as part of the E-PRTR webpage ${ }^{6}$. The BiPRO E-PRTR webpage presents available data with respect to emissions from diffuse sources ${ }^{7}$ at country level, for specific pollutants, divided into releases to water, soil and air. And, as may be observed, the available data are extremely limited in the case of PCBs and HCB. A description of available knowledge according to the description provided of each diffuse source by BiPRO is given below. It should be mentioned here that the main focus has been on potential industrial sources as these are judged of major importance in relation to diffuse sources. Still, some of the scattered sources may be of concern with regard to the local environment despite being of little importance in relation to the total emission. Information on emission estimates from diffuse sources is given in Chapter 3 together with the large industrial point sources.

\subsubsection{Sources to air emissions}

Mobile sources

Mobile combustion is, according to the E-PRTR regulation defined as a diffuse source. Mobile combustion in the Nordic countries has been approached based on fuel consumption. A short description of the sources is given below. Activity data are summarized in Table 16.

\section{Road transport}

Road transport is a diffuse source sector used for the inventory of emissions to air. According to $\mathrm{BiPRO}^{8}$, data in the inventory should sum up figures from NFR codes NFR 1A3b 'fuel combustion in road transportation', including (i-vii) combustion releases from passenger cars, light and heavy duty, mopeds and motorcycles, gas evaporation, tyre and brake wear and road abrasion, and NFR 1A3e 'other transportation' composed of pipeline compressors and other mobile machinery. Details regarding emission

\footnotetext{
${ }^{5}$ Diffuse sources are the many smaller or scattered sources from which pollutants may be released to land, air or water, whose combined impact on those media may be significant and for which it is impractical to collect reports from each individual source

${ }^{6}$ http://www.bipro.de/_prtr/sub/purpose_scope.htm

${ }^{7}$ http://www.bipro.de/__prtr/sub/database.htm
} 
factors are provided in Annex 1, Table 1.3 and 1.4. In the current project, activity data on fuel consumption as given in Table 16 have been available for all countries. For Denmark, activity data in units of driven kilometres in passenger cars divided into diesel and gasoline were available.

\section{Shipping}

Shipping is a diffuse source sector used for the inventory of emissions to air. In this context exclusively emissions from fuel combustion from NFR code 'national navigation' (NFR 1A3d ii) have been summed. Emissions from ships (NRF1A3d ii) are reported in Table 19 together with other diffuse and point sources originating from the use of fuels.

\section{Aviation}

Aviation is a diffuse source sector used in the inventory of emissions to air. In this context only emissions from domestic aviation (1A3a ii including LTO and cruise) have been summed. This source may be relevant but has not been included due to missing information concerning the relevance of the source for the emission of HCB and PCBs.

\section{Rail}

Railways are a diffuse source sector used in the inventory of emissions to air. In this context data compiled in the inventory refer solely to emissions from fuel combustion (NFR 1A3c). No information regarding this activity has been addressed during the review process. The source is considered not relevant for HCB and PCB emission.

Table 16 Activity data on fuel consumption within mobile combustion sources* [tonnes]

\begin{tabular}{|c|c|c|c|}
\hline \multicolumn{4}{|l|}{ 3. Transport } \\
\hline a. Civil Aviation & Aviation Gasoline & Jet Kerosene & \\
\hline Denmark & 2192 & 40373 & \\
\hline Finland & 881 & 102910 & \\
\hline Norway & 2300 & 250000 & \\
\hline Sweden & 808 & 209340 & \\
\hline b. Road Transportation & Gasoline & Diesel Oil & \\
\hline Denmark & 1754524 & 2071982 & \\
\hline Finland & 1739093 & 2013333 & \\
\hline Norway & 1582000 & 1995000 & \\
\hline Sweden & 3783255 & 2297562 & \\
\hline d. Navigation & Residual Oil (Residual Fuel Oil) & Gas/Diesel Oil & Gasoline \\
\hline Denmark & 37038 & 125550 & 8983 \\
\hline Finland & 46548 & 69860 & 51136 \\
\hline Norway & 162000 & 354900 & NO \\
\hline Sweden & 76345 & 71178 & 24375 \\
\hline
\end{tabular}

*IPCC nomenclature

References:

National expert knowledge and Inventory Reports submitted in 2007 http://unfccc.int/national_reports/annex_i_ghg_ inventories/national inventories_submissions/items/3929.php 
Military

Military is used as a diffuse source sector in the inventory on emissions to air. Figures reported for this sector correspond to 'other stationary fuel combustion activities including military' (NFR 1A5a) and 'other mobile fuel combustion activities including military’ (NFR 1A5b). Stationary activities included as military installations are similarly scattered and widespread, as is the residential sector, and are not included in the reporting on 'large' point sources. The source has not been addressed in the present work as it is not judged of importance.

Domestic fuel consumption

The diffuse source category 'Domestic fuel consumption' has not yet been defined. It may be due to the fact that several investigations (Saarinen et al., 2007; Henriksen et al., 2006) have shown that this source may contribute significantly to the total emissions of dioxins and therefore potentially also PCBs and HCB. According to the data from chemical analysis performed in Poland, residential sources may emit stack gases containing concentrations of PCB around 3 times higher than industrial sources (excluding manufacturing industries) and concentrations of HCB around 2 times higher. This increase in source potential for HCB and PCBs from residential sources is however small compared to that for dioxins, where emissions 25 times higher were observed; co-combustion of domestic wastes with hard coal or wood in simple kitchen stoves or heating boilers was a possible explanation (Guidelines on BAT and Guidance on BEP, 2006).

Table 17 Activity data on domestic fuel consumption, 2005 [tonnes]

\begin{tabular}{lrrr}
\hline 4. Other Sectors & & & \\
\hline a. Commercial/Institutional & Coal & Wood $^{*}$ & MSw \\
Denmark & NO & 52765 & 16440 \\
Finland & NO & 225210 & NO \\
Norway & NO & 9300 & NO \\
Sweden & NO & 93866 & NO \\
b. Residential & Coal & Wood* & MSw \\
Denmark & 317 & 1875115 & NO \\
Finland & 510 & 3413445 & NO \\
Norway & 1316 & 1564000 & NO \\
Sweden & NO & 3513025 & NO \\
\hline
\end{tabular}

NO: Not Occurring

*may include wood waste (national expert knowledge)

References:

National expert knowledge and Inventory Reports submitted in 2007 http://unfccc.int/national_reports/annex_i_ghg_ inventories/national_inventories_submissions/items/3929.php

The emission from residential combustion is reported in Table 21 and 22, Chapter 3, together with emissions from industrial combustion and other emission originating from fuel combustion activities. 
A study on emission of PCDD/F, PCB, and HCB from combustion of firewood and pellets in residential stoves and boilers shows a general correlation between PCB and HCB levels with PCDD/F levels, except for intermittent pellet combustion and plastic waste combustion, which seem to favour dioxin formation rather than general POP formation. The PCBs generally contribute approximately $10 \%$ to the TEQ values (Hedman et al., 2006).

\section{Solvent use}

Solvent use includes emissions to air from degreasing, dry cleaning (NFR 3B) and other applications including products containing UPOPs. This source is included in the Chemical Industry emission estimates (NFR 3B and 3D); NFR 3A are not of relevance for any of the Nordic countries as the production, marketing and use of PCBs is prohibited in the Nordic countries (cf. Table 1).

Table 18 Activity data for solvent use in the Nordic Countries [tonnes]

\begin{tabular}{|c|c|c|c|c|c|c|c|c|}
\hline Year & 1999 & 2000 & 2001 & 2002 & 2003 & 2004 & 2005 & Reference \\
\hline \multicolumn{9}{|c|}{$\begin{array}{l}\text { Organic Chemicals } \\
\text { production }\end{array}$} \\
\hline \multicolumn{9}{|c|}{$\begin{array}{l}\text { Chlorine-containing } \\
\text { solvents - use }\end{array}$} \\
\hline Denmark & 35161 & 32718 & 32069 & 29823 & 19051 & 245 & 187 & 1 \\
\hline Finland & 1350 & 1250 & 1094 & 1421 & 1407 & 1110 & 1317 & 2 \\
\hline Norway & NR & NR & NR & NR & NR & NR & NR & \\
\hline Sweden & NR & NR & NR & NR & NR & NR & NR & \\
\hline
\end{tabular}

NR: Not Reported

References:

1: Statistics Denmark

2: Saarinen et al, 2007

Solvent use is considered a diffuse source; solvent use in downstream industries (textile industry) or private use. The decline in the figures for Danish solvent use is due to the substitution and chlorinated solvent taxes (DEPA, 1999; Speck et al., 2006). The Finnish figures on solvent use are fairly constant over the years, indicating that only production and not use has been regulated in Finland. No knowledge concerning the use in Sweden and Norway has been reviewed as this sector is judged of minor importance.

Fossil fuel distribution of natural gas

Fossil fuel distribution of natural gas is a diffuse source sector used in the inventory of releases to air. The sector uses data from NFR 1B2b 'distribution of natural gas' because the emissions are expected to stem from non-point-sources such as pipelines. Data from NFR codes for fossil fuel distribution oil, other, venting and flaring are not taken into account, because activities are expected to occur predominantly at large point sources such as refineries and as such are reported under point sources. This source is not relevant for PCBs and HCB emissions. 
Roofing and road paving with asphalt

According to the definition given by BiPRO, asphalt roofing and road paving with asphalt is a diffuse source sector used in the inventory of releases to air, summing data from NFR codes 2A5 and 2A6. An additional activity originating from asphalt production is polyurethane processing for use in asphalt blowing, NRF code 3C, which may be a source of PCB and HCB emission to air (Saarinen et al., 2007).

Table 19 Total Production of Hot Mix Asphalt in 1993-2005 [1000,000 tonnes]

\begin{tabular}{lccccccccccccc}
\hline Year & $\mathbf{1 9 9 3}$ & $\mathbf{1 9 9 4}$ & $\mathbf{1 9 9 5}$ & $\mathbf{1 9 9 6}$ & $\mathbf{1 9 9 7}$ & $\mathbf{1 9 9 8}$ & $\mathbf{1 9 9 9}$ & $\mathbf{2 0 0 0}$ & $\mathbf{2 0 0 1}$ & $\mathbf{2 0 0 2}$ & $\mathbf{2 0 0 3}$ & $\mathbf{2 0 0 4}$ & $\mathbf{2 0 0 5}$ \\
\hline Denmark & 3.3 & 3.1 & 3.4 & 3.6 & 3.5 & 3.1 & 3.3 & 3.3 & 2.8 & 2.8 & 2.9 & 3.6 & 3.2 \\
Finland & 5.2 & 4.1 & 5.1 & 5.2 & 3.8 & 3.7 & 4.1 & 3.8 & 3.6 & 4.1 & 4.9 & 4.5 & 5.0 \\
Norway & 4.7 & 4.5 & 4.1 & 4.9 & 5.0 & 4.7 & 4.8 & 4.5 & 4.1 & 3.9 & 4.1 & 4.5 & 5.1 \\
Sweden & 7.5 & 7.6 & 7.3 & 5.8 & 5.3 & 6.3 & 7.3 & 7.2 & 6.7 & 6.7 & 6.6 & 6.8 & 7.2 \\
\hline
\end{tabular}

In Sweden, a large country with a relatively low population density and high aggregate availability, some examples of recycling rates are: $45 \%$ of blast furnace slag, corresponding to 0.5 million tonnes used out of 1.1 million tonnes produced; $100 \%$ of steel slag, corresponding to 0.22 million tonnes used and produced; and 95\% Reclaimed Asphalt Pavement (RAP) corresponding to 0.84 million tonnes used out of 0.88 million tonnes produced.

In Denmark, with a high population density and low natural aggregate availability, the recycling rates are: $100 \%$ of steel slag, corresponding to 0.066 million tonnes used and produced; $81 \%$ of crushed concrete, corresponding to 0.95 million tonnes out of 1.17 million tonnes produced; $100 \%$ of coal bottom ash, corresponding to 2 million tonnes used and produced; $100 \%$ of coal fly ash, corresponding to 1.17 million tonnes used and produced; and $100 \%$ of RAP, corresponding to 0.53 million tonnes used and produced.

Recycling rates in the asphalt industry are high, and there may be a need for further investigation of the quality requirements for the recycled material with respect to the risk of run-off and infiltration of soil; i.e. releases to soil and groundwater. In the report by BiPRO (BiPRO, 2006) it is stated that information on emissions in the industry is limited. BiPRO recommends a low priority for action, although only partially refer to unintentional releases of POPs.

Agriculture

With respect to releases to air, agriculture sums releases from fuel combustion in agriculture, fishing and forestry (NFR 1A4c), enteric fermentation (NFR 4D), manure management (NFR 4B), rice cultivation (NFR 4C), agricultural soils (NFR 4D), field burning of agricultural wastes (NFR 4F) and other agricultural processes (NFR 4G). According to Bi- 
PRO, these subcategories are not always strictly diffuse, but it can be stated that a maximum of $10 \%$ of the releases compiled under agriculture as diffuse source sector in this inventory might originate from point sources as defined under E-PRTR. Activity data related to fuel combustion for energy production are shown below.

Table 20 Activity data on fuel consumption in agriculture, 2005 [tonnes]

\begin{tabular}{lrrr}
\hline c. Agriculture/ForestrylFisheries & Coal & Wood & MSW \\
\hline Denmark & 73347 & 8337 & NO \\
Finland & 6000 & 421429 & NO \\
Norway & NO & 4300 & NO \\
Sweden & NO & 14034 & NO \\
\hline
\end{tabular}

Field burning of agricultural waste, NFR 4F, is not relevant for Denmark (Henriksen et al., 2006 and Saarinen et al., 2007; Statutory Order on Waste, no. 619 of 27 June 2000). Still, emission factors for accidental burning may be obtained from Annex 6 .

\subsubsection{Sources to emissions to water}

Agriculture

With respect to releases to water, agriculture involves the sum of releases from agricultural processes. This is usually closely connected to releases from agricultural soils. Releases from this sector are mainly due to the application of artificial or natural fertilizer. Precipitation, erosion, digging and artificial irrigation, as well as natural leaching processes subsequently causes the release of the nutrients applied to the aquatic environment. As mentioned in Chapter 2.1 in relation to the chemical industry, chlorinated pesticides are not used in Sweden and Denmark, whereas there may still be some use in Norway and Finland. The release of HCB with the use of pesticides is judged of no importance for the unintentional emission of HCB (see Table 3.4 in Annex 3); therefore there is no risk of future water contamination via run-off.

\section{Scattered Dwellings}

Scattered dwellings represent a diffuse source sector used in the inventory of releases to water defined as discharge from households not connected to urban waste water treatment plants and other diffuse emissions as surface runoff from paved areas. The fraction of the population not connected to urban wastewater treatment systems corresponds to $10 \%$ of the population in Denmark (Thomsen and Lyck, 2005). The source is judged of no relevance for unintentional emission of UPOPs.

Surface runoff from paved areas may be a potential source of release to soil and continental water bodies of PCBs and HCB. In the case of the recycling of slag in the production of roads and pavements there may be a 
risk of PCB release in surface rainwater runoff. In Denmark $85 \%$ of the residue material from combustion is recycled into the Energy and/or Industry sector. The cement, asphalt and building and construction industries use combustion residues as feed material for production processes.

Diffuse sources of release of HCB and PCBs to surface water may in general result from increased background concentrations caused by e.g. historical contaminated soils by e.g. accidental/minor leakages from old landfills, wash-off releases from contaminated buildings and precipitation of stack emissions from residential combustion and residues of old preserved woods and, in general, old equipment including PCBs and HCB. The diffuse sources are not quantifiable but assumed small and maybe comparable to releases from wastewater effluents in which both PCBs and HCB have low detection frequencies.

The main source of PCB and HCB pollution of surface waters is judged to be historical build-up of UPOPs in the sediments due to diffuse and point sources as well as historical dumping activities and industrial activities in harbours; e.g. accidental waste oil spills and the use of ship paints containing PCBs.

\subsubsection{Sources to releases to soil}

Releases to soil from diffuse sources have yet to be defined on the BiPRO webpage (http://www.bipro.de/). Some obvious sources that may contribute to soil contamination are discussed below.

\section{Deposition and Evaporation}

Atmospheric deposition from scattered sources, e.g. residential combustion, may be considered a source, even though in some cases the sourcesink relationship between air and soil points in the reverse direction; i.e. releases from soils to air is the governing process towards equilibrium distribution. Soil/air partition coefficient values for HCB range from 5.0 to 7.3 (Hippelein and McLachlan, 1998; Meijer et al., 2003) and both HCB and PCB exchange between soil and air occurs continuously (KurtKarakus and Jones, 2006); according to Barber and Jones (Barber and Jones, 2005) a re-emission from soil may occur in the case of HCB.

Several studies have measured distance to source concentration profiles in soil, both for industries and contaminated buildings (e.g. Capuano et al., 2005; Herrick et al, 2007; Sikkonen et al., 1997). Soil contamination from deposition from industrial point sources as well as contaminated buildings is considered of minor importance compared to other sources; however, local environments may be of concern in the case of vulnerable areas such as kindergartens. Emissions from contaminated building components such as sealants, plastics and windows (Andersson, 2002; Trap et al., 2006) may lead to soil contamination (Andersson et al., 2003; Meijer et al., 2003; Ottesen et al., 1999; Veritas, 2000) to a degree 
that may involve elevated background soil concentrations above 0.5 $\mathrm{mg} / \mathrm{kg}$ (Andersson et al., 2003). Furthermore, several studies address near exposure caused by indoor emissions from building materials. Several studies in Denmark, Finland, Norway and Sweden verify the significance of emissions from buildings including from PCB-containing sealants or other PCB-containing building components (e.g. SBI, 1999; Sverud and Estensen, 2000).

Sludge as fertilizer in agriculture and parks

A Danish investigation from 2002 (Vikelsoe et al., 2002) shows that the soil concentration of PCB is lower than the non-halogenated contamination level. When looking at the sludge to soil ratios for highly contaminated areas were above unity in depositing locations, with a PCB concentration at the level of 130,550 and 0.1 to $0.4 \mu \mathrm{g} / \mathrm{kg}$ dry matter for respectively sludge, polluted soil and two agricultural soils. Depending on the pollution level soil may act as a sink or source with regard to UPOPs.

Industrial activities and remediation

Industrial activities such as automobile repair facilities (Nordisk Ministerråd, 2007) may contribute to releases of PCBs from disposed car wrecks and parts including residue oils, etc. In addition, gasoline stations may have been classified as having polluted soils in national mapping of soil qualities according to land-use sensitivity criteria. In Denmark, many activities have been performed aimed at remediation of polluted soils, with special focus on clean-up of historical pollution from industry. Emissions from clean-up of PCB contaminated soil, at an initial concentration level of $37.5 \mathrm{mg} / \mathrm{kg}$, by thermal desorption processes has been recorded at $1.14 \mathrm{~g} / \mathrm{h}$ at uncontrolled conditions and $0.05 \mathrm{~g} / \mathrm{h}$ under controlled conditions (IPPC, BAT on WT, 2006; Eklund et al, 1997).

Similar clean-up activity has been performed in Sweden, Norway and Finland and in this respect mapping of soil qualities has taken place as illustrated in the paragraphs below.

Polluted soils

In Norway 161 polluted locations have been identified (http://www. sft.no/grunn/); however, the concentration levels of soil pollution are not available. 474 locations are polluted with PCBs and 15 with HCB. Locations are described in detail and divided into the location types: polluted areas, industrial disposal sites and municipal disposal sites.

Sweden has divided polluted areas into industrial branches typical with regard to PCB pollution. As such secondary metal production and processes are listed together with the electronic industry, paper industry, ships and harbours, car scrap and scrap dealers (Naturvårdsverket, 1999).

In Denmark a mapping and characterization of areas according to soil quality criteria and land uses has been performed to ensure protection of 
drinking water interests, environment and health (Lov om forurenet jord, $\S 4$, lov nr. 370 af 2. juni 1999). The so-called V1 and V2 mapping results will be available from the Danish environmental portal (http://www. miljoeportal.dk/Jordforurening/), which is under development. At this point the database is not publically available and only 4 locations have been identified as PCB polluted and no locations are listed as polluted with HCB.

Releases to soil, water and air from scattered sources are judged of minor importance compared to point source sectors when assessing sources of measured concentrations in the distal environment. Still, the concentrations of the total intake of the general European population measured indicate that human exposures from diffuse scattered sources in the proximal environment of humans may need further research. So, even though diffuse sources are of minor importance regarding total emissions of PCBs and HCB to soil, air and water, they may be important sources in relation to human exposure. Therefore, several studies address the increased background concentrations as a concern with regard to human exposure levels. In relation to the E-PRTR reporting scheme, this aspect is addressed in e.g. Wiberg et al., 2007. 



\section{Estimation of emissions and releases of HCB and PCBs}

Emission estimates are based on specific activities at country level, as provided in Chapter 2 for each identified potential diffuse or point source for which the necessary data are available. Activity data are multiplied by the emission factor that is judged as most suitable or, if only one relevant emission factor has been found, the available one. Details concerning available and selected emission factors are given in Appendix 1 to 6 . Information regarding emissions to soil and water from the energy and industry sectors is limited; nevertheless, activity data for these sources have as far as possible been included in Chapter 2. It is assumed that the potential major sources of release to soil and water may origin from offsite transfer of residue/waste products and wastewater discharge to the municipal sewer system. Therefore, potential sources of unintentional release of HCB and PCBs to soil and water have been included in Chapter 3.3, which presents available information relevant for PRTR code 5 'waste and wastewater management'.

The estimated emissions of PCBs and HCB to air are divided into point sources, according to Table 2, and diffuse sources as defined in Chapter 2. Large point sources and resulting reporting obligations becomes a requirement if the reporting thresholds as given in Table 2 are exceeded at the single-plant level. It is outside the scope of this work to perform a detailed investigation of the numbers of plants operating within each country. The current chapter presents, therefore, only indicative estimates of the importance of identified sources. It only to a limited extent takes into account that some countries may carry out more accurate inventories on these substances with national methodologies.

The indicative emission estimates should be divided by the number of plants operating within each sector to obtain an indication of the emission level compared with reporting thresholds. All figures in this chapter should be considered as indicative only.

The threshold values in the EU PRTR regulation for reporting at facility level (Regulation (EC) No 166/2006), are relevant, since a main aim of this project is to improve the ability of the Nordic countries to adequately report on emissions of unintentional emissions of HCB and PCB's. Where possible it will therefore be indicated whether emissions seem to be of a magnitude where reporting is required under the PRTR regulation. The threshold values for HCB are $10 \mathrm{~kg} / \mathrm{year}$ per facility for emissions to air, while they are $1 \mathrm{~kg} /$ year for emissions to water and soil. 
The threshold values for PCBs are $0.1 \mathrm{~kg}$ for emissions to air, water and soil alike.

\subsection{Emissions related to energy production}

Table 21 and 22 includes emission estimates for HCB and PCB respectively from energy production within the energy sector and the industrial sector. The tables include emissions from point sources as well as from fuel combusting activities categorized as diffuse sources. Activities for potential point and diffuse sources are described in Chapters 2.1 and 2.2, respectively.

Table 21 Indicative HCB emissions from fuel consuming activities (2005*)

\begin{tabular}{lrrr}
\hline Point sources & & & \\
Stationary combustion [g/yr] & Coal & Wood & MSW \\
Denmark & 99 & 100 & 3501 \\
Finland & 67 & 1248 & 361 \\
Norway & 3 & 42 & 697 \\
Sweden & 13 & 749 & 3250 \\
Diffuse sources & & & \\
Mobile combustion [g/yr] & Gasoline & Diesel Oil & Fuel independent \\
Denmark & 1 & 275 & 230 \\
Finland & & & 225 \\
Norway & & & 215 \\
Sweden & & & 365 \\
Stationary combustion [mg/yr] & Coal & Wood & MSW \\
Denmark & 2 & 9903 & 17 \\
Finland & 3 & 19321 & NO \\
Norway & 7 & 7913 & NO \\
Sweden & NO & 18504 & NO
\end{tabular}

NO: Not Occurring

*or closest to, see Annex 1-6 for details regarding reference to specific activity data and emission factors

Table 21 indicates that the contribution to HCB emissions from diffuse sources is smaller than the contribution from point sources, except for combustion of wood. For Denmark, emissions for mobile combustion mainly road transport - were divided into fuel types, and, as expected, emissions from diesel-fuelled vehicles dominate (see also Table 1.4. in Appendix 1). Mobile sources include national navigation, from which the contribution to the estimated emissions is insignificant.

Based on the estimated HCB air emissions from the Energy sector and energy consumption in the industrial sectors, none of the Nordic countries seem to be at risk of exceeding the PRTR reporting threshold value for HCB. 
Table 22 Indicative PCB emissions from fuel-consuming activities [g/yr] (2005*)

\begin{tabular}{lrrr}
\hline Point sources & Coal & Wood & MSW \\
Stationary combustion & 54657 & 1051 & 2871 \\
Denmark & 36836 & 13103 & 296 \\
Finland & 1383 & 441 & 572 \\
Norway & 7402 & 7863 & 2665 \\
Sweden & & & \\
Diffuse sources & Gasoline & Diesel Oil & Fuel independent \\
Mobile & & & 19133 \\
Denmark & & & 18762 \\
Finland & & & 17885 \\
Norway & & & 30404 \\
Sweden & Coal & Wood & MSW \\
Stationary combustion & 147 & 1917 & 13 \\
Denmark & 13 & 3977 & NO \\
Finland & 3 & 1574 & NO \\
Norway & NO & 3586 & NO \\
Sweden & & & \\
\hline
\end{tabular}

NO: Not Occurring

*or closest to, see Annex 1-6 for details regarding reference to specific activity data and emission factors

In table 22, the estimated emission level for PCB seems unrealistically high compared to the estimated level of HCB for point sources. Some investigations show that HCB emission levels to air significantly exceed the PCB emissions (e.g. Kim et al., 2004 and Bergquist et al, 2005). The same situation is valid for mobile sources and small combustion sources. An explanation may be that emission factors representative for the Nordic countries have been derived for HCB (e.g. Saarinen, 2007), while the same country-specific emission factors (EFs) have yet to be derived for PCBs (cf. Annex 1, Table 1.2 and 1.3).

PCB emission from petroleum refineries is categorized as a PRTR 1a activity. An emission factor to air for PCB of $1 \mathrm{mg} / \mathrm{t}$ refined fuel has been reported for the activity 'Petrol Refinery' (BiPRO, 2006). Based on this information, emission of PCBs from oil refinery processes is given in Table 23.

Table 23 РСB air emissions from production of refined petroleum [g/yr]

\begin{tabular}{lrrrrr}
\hline Petrol refinery & $\mathbf{2 0 0 1}$ & $\mathbf{2 0 0 2}$ & $\mathbf{2 0 0 3}$ & $\mathbf{2 0 0 4}$ & $\mathbf{2 0 0 5}$ \\
\hline Denmark & 9821 & 7890 & 8143 & 8157 & 8320 \\
Finland & 5772 & 7475 & 7496 & 8325 & 10748 \\
Norway & 17596 & 17732 & 18005 & 14066 & 15408 \\
Sweden & 19593 & 19314 & 19662 & 20612 & 19920 \\
\hline
\end{tabular}

The estimated PCB emission level from refineries is indicated to be of importance but to be below the emission estimates from road transport. The importance of stationary fuel-consuming point sources of PCB 
emissions is particularly great in the case of Finland and Denmark, due to a high use of coal, which has a high emission factor (see Table 1.3 in Annex 1).

The estimated emission level for the energy sector is indicated to be above the E-PRTR reporting threshold for PCB.

\subsection{Emissions from the metal, mineral and chemical industries}

Table 24 Indicative HCB air emissions originating from industry [g/yr]

\begin{tabular}{llrrrrr}
\hline PRTR code & Source sector & $\mathbf{2 0 0 1}$ & $\mathbf{2 0 0 2}$ & $\mathbf{2 0 0 3}$ & $\mathbf{2 0 0 4}$ & 2005 \\
\hline $\mathbf{2}$ & Metal industry & & & & & \\
& Denmark & 1504 & 796 & 12 & 13 & 13 \\
& Finland & 8088 & 8220 & 9754 & 9886 & 9694 \\
& Norway & 12713 & 5078 & 1778 & 1828 & 1816 \\
& Sweden & 4897 & 5034 & 4713 & 4842 & 4660 \\
& Mineral industry & & & & & \\
$\mathbf{3}$ & Denmark & 27 & 28 & 26 & 29 & 28 \\
& Finland & 30 & 30 & 27 & 28 & 28 \\
& Norway & 14 & 13 & 13 & 14 & 14 \\
& Sweden & 31 & 31 & 30 & 31 & 32 \\
& Chemical industry & & & & & \\
$\mathbf{4}$ & Denmark & 63 & 9 & NR & 4068 & 804 \\
& Finland & 8190 & 2480 & 460 & 16700 & NR \\
& Norway & NR & NR & NR & NR & NR \\
& Sweden & NR & NR & NR & NR & NR \\
\hline
\end{tabular}

NR: Not Reported

Table 24 shows the indicative HCB emissions originating from industry. When comparing the industrial sectors assumed to have the largest unintentional HCB emissions to air, the metal industry is clearly dominant as a source of unintentional emission of HCB to air. As mentioned in Chapter 2, the metal industry is also the most intensive industry regarding the production of output material in terms of waste and/or by-products.

The chemical industry is of major importance for Finland due to their potassium sulphate production. Some sources within the chemical industry may be insufficiently represented, e.g., as mentioned in Chapter 2 regarding pesticide production in Denmark. In general, more research on the chemical industry regarding potential emissions is required, as they may be of more importance than perceived earlier. For example, the estimated emission of HCB to air from the chemical industry in Sweden has been estimated at above $12 \mathrm{~kg} / \mathrm{yr}$ in a study carried out by Bergquist et al., 2005.

The decreasing figures in table 24 for the Norwegian metal industry are due to the cessation of magnesium production in 2002. The generally 
high figures for Finland are explained by the high activity in EAF plants in the iron and steel sector.

The use of chemicals is categorized as a diffuse source and the indicative emissions are given in Annex 3, Table 3.3 and Table 3.4. Data on pesticide use has only been identified for Finland resulting in an indicative HCB emission of $2 \mathrm{~g}$ in 2006. Based on available information, the emission from the use of pesticides including residues of HCB is assumed of minor importance compared to that from organic solvent use (see Table 3.3 in Annex 3).

Table 25 Indicative PCB air emissions originating from industry [g/yr]

\begin{tabular}{|c|c|c|c|c|c|c|}
\hline PRTR code & Source sector & 2001 & 2002 & 2003 & 2004 & 2005 \\
\hline \multirow[t]{5}{*}{2} & Metal industry & & & & & \\
\hline & Denmark & 1180 & 649 & 61 & 68 & 68 \\
\hline & Finland & 9847 & 9925 & 11042 & 11169 & 10991 \\
\hline & Norway & 1729 & 1982 & 1942 & 2250 & 2289 \\
\hline & Sweden & 8059 & 7795 & 7554 & 8099 & 7949 \\
\hline \multirow[t]{5}{*}{3} & Mineral Industry & & & & & \\
\hline & Denmark & 5338 & 5417 & 5107 & 5736 & 5426 \\
\hline & Finland & 2956 & 2728 & 2660 & 2875 & 2972 \\
\hline & Norway & 3755 & 3715 & 3735 & 3755 & 3815 \\
\hline & Sweden & 5364 & 5371 & 5071 & 5298 & 5551 \\
\hline
\end{tabular}

Table 25 shows indicative PCB emissions from industry. No sources of unintentional emission of PCB from the chemical industry have been identified. For Sweden and Finland the same pattern as for HCB is seen; i.e. that the metal industry is suggested to be the main emission source when compared to the mineral industry. For Norway and Denmark the figures suggest the opposite. The higher figures from the Finnish and Swedish metal industries compared to those in Denmark and Norway may be explained by the high activity in iron and steel production processes, i.e. sinter and EAF plants, as well as coke production.

The figures indicate activity levels above the reporting threshold, as given in Table 2, of $100 \mathrm{~g} / \mathrm{yr}$ at single facility-level for sinter and EAF plants in Finland and Sweden. For cement-producing plants, the figures for Denmark are indicated to be above the reporting threshold (see Annex 2, Table 2.5). Depending on the number of cement production facilities in the remaining Nordic countries, reporting could be relevant.

Both the metal and to a lesser extent the mineral industries produce by-products; mass flows that will be registered as off-site transfer. More detailed mass flow analysis regarding the content of HCB and/or PCB needs to be undertaken in order to assess their contribution to unintentional releases to water and soil. 


\subsection{Emissions from waste and wastewater management}

The EU directive on waste has contributed to the establishment of detailed waste categories for recycling and sorting as well as guidelines on their implementation, which are to be used at municipal level, for example at recycling stations. However, historical data are hard to categorize, since disposal categories, including for hazardous/non-hazardous waste, have varied between countries. The emissions estimated are therefore even more uncertain for this sector. Technical aspects and guidelines (e.g. Basel 2007a and 2007b) for best environmental practices may be found at the Basel webpage http://www.basel.int/techmatters/index.html.

\subsubsection{Indicative emissions to air}

EU directives as well as national regulation in the Nordic countries have been and are drivers for decreased final disposal of waste as landfill and increased combustion with energy recovery, using the organic burnable fraction of the household and industrial waste categories. Despite an increase in waste being combusted with and without energy recovery, a decrease in the emission of dioxins, and presumably also HCB and PCBs, has been observed, due to increased air pollution control requirements. In addition to high technology flue-gas cleaning, an increased sorting of waste, removal of precursor material such as metals and plastics and optimization of the combustion processes have resulted in the reduced emission of unintentional POPs.

In Denmark, shredder plants have been targeted as a possible major source of Danish PCB-emissions. PCB mainly exists in electric and electronic waste and building materials with a long lifespan. Despite regulation on separate collection of such waste, some ends up in shredder plants. A survey done in 2006 (ref lab 2006) for the 6 shredder plants in Denmark shows a mean of $11,3 \mu \mathrm{g} / \mathrm{Nm}^{3}$ for measures of emissions to air for 200406. It further estimates a total emission of $3 \mathrm{~kg} /$ year from the 6 plants.

Waste incineration

The emissions from waste incineration (or combustion) have been divided into municipal waste and 'hazardous waste', where the term 'hazardous' covers classification terms like e.g. 'problemavfall' ('problem waste' - Finnish waste statistics), but is mostly to be read as 'industrial waste'. In the Danish waste statistics report (DEPA 2006), the final waste disposal category 'combustion' includes municipal sludge, hazardous waste from households, service, industry and building and construction. It has not been possible to differentiate between waste incineration and combustion with energy recovery. The many and changing definitions and categorizations of waste types may be observed from reported emis- 
sions factors (see Table 4.2 and 4.3 in Annex 4) and available data on combustion as the final disposal route (see Table 4.1, Annex 4).

The figures in Table 26 are therefore more uncertain then the remaining activity data presented in this report. The differences in amounts of waste may partly be explained by import-export loads of non-hazardous waste. Detailed coverage of the changes in the definitions of waste fractions and treatment technologies is not within the scope of the present work. See also see Table 4.1, Annex 4 for further information. A few comments to the figures in Table 26 are given below.

Table 26 HCB and PCB emission to air from combustion of waste with and without energy production

\begin{tabular}{|c|c|c|c|c|c|}
\hline $\begin{array}{l}\text { Activity [tonnes], } \\
\text { average 2004-2005 }\end{array}$ & & EF_HCB $[\mu g / t]$ & EF_PCB $[\mu \mathrm{g} / \mathrm{t}]$ & $\begin{array}{c}\text { Emission } \mathrm{HCB} \\
{[\mathrm{g} / \mathrm{yr}]}\end{array}$ & $\begin{array}{c}\text { Emission PCB } \\
{[\mathrm{g} / \mathrm{yr}]}\end{array}$ \\
\hline Hazardous waste & & 10000 & 5000 & & \\
\hline Denmark & 86490 & & & 865 & 432 \\
\hline Finland & 7214751 & & & 72148 & 36074 \\
\hline Norway & 574246 & & & 5742 & 2871 \\
\hline Sweden & 1440640 & & & 14406 & 7203 \\
\hline Municipal waste & & 2000 & 820 & & \\
\hline Denmark & 1468500 & & & 2937 & 1204 \\
\hline Finland & 239924 & & & 480 & 197 \\
\hline Norway & 226843 & & & 454 & 186 \\
\hline Sweden & 1944290 & & & 3889 & 1594 \\
\hline
\end{tabular}

In the case of Denmark, 135,000 tonnes of 'no reporting required' waste explains the large amount of municipal waste. Another explanation for the relatively high amounts of municipal waste use for energy production may be the Danish waste strategy and a goal of no landfill disposal, increased reuse and increased waste to energy production.

Regarding the high amount of hazardous waste for combustion in Sweden and especially Finland, this may be due to import of e.g. shredder waste from Denmark and other countries.

According to the Swedish and the first Nordic report submitted to EU on waste statistics (EU regulation no. 1379/2007), the Swedish way of reporting waste statistics may differ slightly regarding e.g. the European waste categories on waste for incineration (Swedish Environmental Protection Agency, 2006). According to the Swedish waste management report, hazardous waste, given in Table 26, includes imported household waste (RVF, 2006).

Until recently waste has been categorized as hazardous or nonhazardous waste across all sectors (e.g. DEPA, 2007). The figures in Table 26 and Annex 4 may reveal a need for a more in-depth analysis of waste categories, import-export and final disposal and recovery categories. Details regarding available emission factors and waste types are addressed in Annex 4, table 4.1 to 4.3.

The emission factors given in Table 26 have been selected as either the most updated or the only available emission factors (see also Annex 4, 
Table 4.2 and 4.3). The emission factors are expected to be overestimated in view of the actually applied waste treatment technologies in the Nordic countries and could be improved through monitoring of the stack gases. In the BREF for Municipal Solid Waste Incineration (MSWI) an average annual PCB emission factor of $<0.005 \mathrm{mg} / \mathrm{Nm}^{3}$ is given (IPPC BREF on WI, 2006). For comparison, this would result in an emission of maximum $15000 \mathrm{~g} / \mathrm{yr}$ for a Danish plant releasing $3.110^{9} \mathrm{Nm}^{3}$ stack gas per year. Approximately 12-13 of such waste combustions plants would result in an annual PCB emission from waste incineration of 200,000 g/yr, which according to BiPRO is low compared to other sectors (BiPRO, 2005). The latter is not confirmed by the present work.

Estimation in relation to dioxin emissions to air seems to confirm that emissions of HCB from waste incineration are overestimated, since cleaning flue gas for dioxin is generally considered to also reduce emissions of other substances, such as HCB. A recent Danish report (ref lab, 2007) estimates that dioxin emissions have been reduced from $21.1 \mathrm{~g} \mathrm{I}-\mathrm{TEQ} /$ year in 1999 to $0.38 \mathrm{~g} \mathrm{I-TEQ/year} \mathrm{in} \mathrm{2006,} \mathrm{a} \mathrm{reduction} \mathrm{of} \mathrm{more} \mathrm{than} 98 \%$.

Information and knowledge regarding releases to land, releases from diffuse sources and off-site transfers has not been prioritized for an indepth analysis in this study as data are extremely scattered and sparse (e.g. Andrijewski et al, 2004; Naturvårdsverket, 2005; BiPRO, 2006).

Fugitive emissions from wastewater treatment plants (WWTP)

According to a Swedish survey, the emission of PCB from aeration tanks has been estimated to 150-200 g of total PCBs/yr to air in Sweden in 2004. For HCB, the estimate is $1-2 \mathrm{~g} / \mathrm{yr}$ from Swedish sewage treatment plants (Naturvårdsverket, 2005).

According to the BREF for waste treatment technologies, an estimated annual emission from anaerobic digestion of MSW source-separated organic material is $0.73 \mathrm{mg}$ PCB/tonne waste (IPPC BREF on WTI, 2006). Knowledge of the amount of source-separated organic fraction of MSW would allow for an estimation of the total PCB emission to air from anaerobic digestion of municipal organic waste.

\section{Emissions from landfill fires and crematories}

The available information on fires at landfill sites and other accidental fires only partly allowed for an estimation of HCB or PCBs emissions in this connection (Annex 6). This source may potentially be of importance for the total air emission of PCBs and HCB, depending on the chlorine and organic matter content of the material deposited at the landfills in question. Furthermore, emissions from crematoria were included for PCB, but are indicated to be of minor importance. 


\subsubsection{Potential emissions to water}

\section{Effluents from centralized WWTPs}

Due to the development of centralized wastewater treatment systems in the Nordic countries, and Europe in general, the release to water from point sources is expected mainly to be related to these waste water treatment plants (WWTPs). Existing data on PCBs and HCB in water at sewage treatment plants are however limited. It is expected that potential sources to emissions with the effluent water vary widely, depending on the number and types of industries connected to the sewer system belonging to individual centralised WWTPs. The load of unintentionally formed POPs in process wastewater from individual industries may result in varying contributions at the centralized WWTPs receiving wastewater from these industries. PCBs and HCB have low solubility in water and therefore high affinity for sorption to organic particles. PCBs and HCB entering the WWTP with the influent wastewater therefore tend to partition into the sludge fraction during wastewater treatment, which expectedly results in lower levels in the effluent from the centralized WWTPs. However, a study by Bergquist et al., 2006, including ten PCB congeners, suggests a concentration of $0.3 \mathrm{ng} / \mathrm{L}$ and $1 \mathrm{ng} / \mathrm{L}$ PCB in the influent and effluent urban wastewater, respectively. Based on the congener patterns it is indicated that the source of PCB content in influent wastewater in Sweden originates from leakages from historic PCB pollution (Bergquist et al., 2006). Reported amounts of influent wastewater for Denmark are in the range of $600-800$ million $\mathrm{m}^{3}$ in the years 1999-2003 (Thomsen and Lyck, 2005). This would imply an influent amount of PCB $0.18-0.24 \mathrm{~kg} / \mathrm{yr}$. The effluent amount of PCB depends on the sorption coefficient and the amount of effluent water; a reduction in the amount of effluent water may to some extent explain the increased measurement by Bergquist et al., 2006.

Effluent water from separate industries

Potentially, there may be a risk of release to water via discharge of treated scrubbing water. Wastewater from wet scrubbing processes includes dust particles. The presence of dust in the wastewater may increase the effluent load of PCB.

\subsubsection{Potential emissions to soils}

Potential sources have been mentioned in Chapter 2. Data regarding emission estimates is limited. Due to similar concentration levels at WWTP slightly above background soil concentrations it is suggested that a recirculation deposited UPOP, and additional contributions from surface runoff, result in re-entrance at WWTPs and a re-emission by spreading of the sludge on agricultural soils. 
Releases with sludge

According to a Swedish study, PCBs occur at higher concentrations than dioxins in sludge, but represent a lower toxicity potential (Naturvårdsverket, 2005). Swedish concentrations of PCB in sewage sludge show a decreasing trend throughout the 1990s. The few data available on HCB indicate that levels of this compound are lower than those of PCBs. Swedish investigations indicate a total quantity of $\mathrm{PCB}_{7}$ in sludge in 2003 of around $2.2 \mathrm{~kg}$ and that the mean concentration weighted by the annual sludge production showed a slight downward trend (Naturvårdsverket, 2005). In Denmark around 80,000 tonnes sludge was used as fertilizer within the agricultural sector annually from 2000-2002 (DEPA, 2003), resulting in an annual release to soil of $0.4-9.6 \mathrm{~kg} \mathrm{HCB} / \mathrm{yr}$ and $0.6-1.4 \mathrm{~kg}$ PCB/yr. The yearly releases to soil are based on the Danish release factors that are at the same levels as given for PCBs (see Chapter 2.1.5).

In addition, deposition from primary sources, even subject to longdistance transport, may contribute to soil concentrations today. Therefore the origin of sources for an estimation of the total deposition is difficult to address.

As the total quantities of PCBs and HCB currently to be found in and around different contaminated sites today may be substantial (see Chapter 2.3.3), such sources could be of appreciable significance for the release of PCBs and HCB, now and/or in the future. Release from soil may be just as important as deposition or release with respect to the environmental fate of PCBs and HCB. Due to the high binding affinity both of HCB and PCBs, risk of contamination of groundwater is minimal (e.g. Naturvårdsverket, 2005).

\subsection{Relative importance of emissions to air in the Nordic countries}

The findings regarding emissions to air can be summarized in the tables below. The tables do not contain the estimated emission numbers, since this could be interpreted as if the estimations have a satisfactory degree of certainty, which is not the case. Instead, the sources have been grouped into 3 categories: Main, medium and lesser, reflecting their probable relative contribution within the separate countries. It was decided not to include sources with an estimated emission under $200 \mathrm{~g} / \mathrm{yr}$, since they seem to be insignificant.

In order to be more readily understandable and closer to wording normally used in common language, some of the names in the table differ from those used in the previous tables in this chapter: Energy production corresponds to "Point sources. Stationary combustion" in table 21. "Mobile sources (road transport)" corresponds to "Diffuse source. Mobile combustion" in table 21, and "Residential combustion" corresponds to "Diffuse 
source. Stationary combustion" in table 21. It is also reflected in the names in the tables that in Denmark, all combustion of waste is combined with energy production, while this is not the case in the other Nordic countries.

\section{Table 27 HCB emissions to air: Probable sources of importance}

\begin{tabular}{|c|c|c|c|}
\hline Country & Main source & Medium source & Lesser source \\
\hline Denmark & $\begin{array}{l}\text { Residential combustion } \\
\text { (wood) } \\
\text { Energy production } \\
\text { (waste)* }^{*}\end{array}$ & $\begin{array}{l}\text { Energy production (com- } \\
\text { bustion of hazardous } \\
\text { waste) } \\
\text { Chemical industry }\end{array}$ & $\begin{array}{l}\text { Mobile sources (road } \\
\text { transport) }\end{array}$ \\
\hline Finland & $\begin{array}{l}\text { Combustion of hazardous } \\
\text { waste } \\
\text { Residential combustion } \\
\text { (wood) } \\
\text { Chemical industry }\end{array}$ & $\begin{array}{l}\text { Metal industry } \\
\text { Energy production (wood) }\end{array}$ & $\begin{array}{l}\text { Energy production } \\
\text { (waste) } \\
\text { Combustion of municipal } \\
\text { waste } \\
\text { Mobile sources (road } \\
\text { transport) }\end{array}$ \\
\hline Norway & $\begin{array}{l}\text { Residential combustion } \\
\text { (wood) } \\
\text { Combustion of hazardous } \\
\text { waste }\end{array}$ & Metal industry & $\begin{array}{l}\text { Energy production } \\
\text { (waste) } \\
\text { Combustion of municipal } \\
\text { waste } \\
\text { Mobile sources (road } \\
\text { transport) }\end{array}$ \\
\hline Sweden & $\begin{array}{l}\text { Residential combustion } \\
\text { (wood) } \\
\text { Combustion of hazardous } \\
\text { waste }\end{array}$ & $\begin{array}{l}\text { Metal industry } \\
\text { Combustion of municipal } \\
\text { waste } \\
\text { Energy production (waste) }\end{array}$ & $\begin{array}{l}\text { Energy production (wood) } \\
\text { Mobile sources (road } \\
\text { transport) }\end{array}$ \\
\hline
\end{tabular}

*Recent studies on dioxin indicate otherwise, see ref lab (2007).

${ }^{\star} *$ The data on emissions from the sources are very uncertain, see also section 3.3.1

Table 28 PCB emissions to air: Probable sources of importance

\begin{tabular}{|c|c|c|c|}
\hline Country & Main source & Medium source & Lesser source \\
\hline Denmark & $\begin{array}{l}\text { Energy production (coal) } \\
\text { Mobile sources (road } \\
\text { transport) }\end{array}$ & $\begin{array}{l}\text { Petroleum refineries } \\
\text { Mineral industry } \\
\text { Waste treatment (shred- } \\
\text { der) } \\
\text { Energy production (waste) }\end{array}$ & $\begin{array}{l}\text { Residential combustion } \\
\text { (wood) } \\
\text { Energy production (wood) }\end{array}$ \\
\hline Finland & $\begin{array}{l}\text { Energy production (coal) } \\
\text { Combustion of hazardous } \\
\text { waste }\end{array}$ & $\begin{array}{l}\text { Mobile sources (road } \\
\text { transport) } \\
\text { Energy production (wood) } \\
\text { Metal industry } \\
\text { Petroleum refineries }\end{array}$ & $\begin{array}{l}\text { Residential combustion } \\
\text { (wood) } \\
\text { Mineral industry } \\
\text { Energy production (mu- } \\
\text { nicipal waste) }\end{array}$ \\
\hline Norway & $\begin{array}{l}\text { Mobile sources (road } \\
\text { transport) } \\
\text { Petroleum refineries }\end{array}$ & $\begin{array}{l}\text { Mineral industry } \\
\text { Combustion of hazardous } \\
\text { waste } \\
\text { Metal industry }\end{array}$ & $\begin{array}{l}\text { Residential combustion } \\
\text { (wood) } \\
\text { Energy production (coal) } \\
\text { Energy production } \\
\text { (waste) } \\
\text { Energy production (wood) }\end{array}$ \\
\hline Sweden & $\begin{array}{l}\text { Mobile sources (road } \\
\text { transport) } \\
\text { Petroleum refineries }\end{array}$ & $\begin{array}{l}\text { Metal industry } \\
\text { Energy production (wood) } \\
\text { Energy production (coal) } \\
\text { Combustion of hazardous } \\
\text { waste } \\
\text { Mineral industry }\end{array}$ & $\begin{array}{l}\text { Residential combustion } \\
\text { (wood) } \\
\text { Energy production } \\
\text { (waste) } \\
\text { Combustion of municipal } \\
\text { waste }\end{array}$ \\
\hline
\end{tabular}





\section{Conclusion}

This study has pointed to a number of likely sources to unintentional releases of HCB and PCBs in the Nordic countries and possible emission magnitudes, and has thereby brought the counries a step closer to being able to report on emissions. However, it has also revealed that with the knowledge available today, a complete assessment of the emissions is not possible and will require further knowledge, including filling the identified gaps.

At an early stage in the elaboration of the study, the significant shortcomings in the existing data and knowledge in general became clear, and focus was therefore directed towards trying to identify the most relevant sources for each country.

Data and information for deriving emissions estimates have shown to be biased towards air releases, with very little information on levels of pollutants in solid residues or liquid discharges. Adequate information was not available on the presence of HCB or PCB in solid and liquid residues.

\subsection{Emission sources}

Overall, the indicative air emission estimates suggest that combustion processes may be a main source of unintentional emission of HCB and PCBs. Regarding HCB, it seems that emissions from residential combustion of wood, a diffuse source, and combustion of waste, especially hazardous waste, are more important sources than combustion processes within the industry and point source energy sectors. The picture is more differentiated regarding PCB emissions, but energy production from coal, mobile sources (road transport) and petroleum refineries seem to be general main sources.

\subsubsection{Country-specific summary of sources of air emissions}

Denmark

HCB: Residential combustion may represent one of the main sources of unintentional emissions of HCB. Combustion of waste, which in Denmark is always combined with energy production, may be another. However, a recent study on trends in dioxin emissions from combustion of waste indicates that this may no longer be the case. Combustion of hazardous waste and the chemical industry are also likely sources. Road 
transport, seem to be of lesser importance. Metal and mineral industries, being very small in Denmark, seem to be insignificant sources.

PCBs: Energy production based on combustion of coal seems to be the main source to unintentional emission of PCB, but road transport may also be of main importance. Petroleum refineries, the mineral industry, waste treatment at shredder plants and energy production from waste may also be sources of some significance, while residential combustion and energy production of wood are likely to be minor sources.

Finland

HCB: The study points to combustion of hazardous waste, residential combustion of wood and the chemicals industry as being the main sources. However, in a recent national study in Finland, the chemical industry was estimated to contribute with up to $81 \%$ of the total emissions in 2004 (Saarinen et al., 2007). This is not consistent with the results of this study, which underlines the uncertainties involved. The Finnish estimation is likely to be more correct. The metal industry and energy production based on combustion of wood are indicated to be sources of some importance. Energy production of waste, combustion of municipal waste and road transport are suggested to be of minor importance.

PCBs: Energy production based on combustion of coal and combustion of waste seem to constitute the main sources of PCB. Road transport, energy production based on combustion of wood, metal industry and petroleum refineries are indicated to be sources of some importance. Residential combustion, the mineral industry and energy production from municipal waste seems to represent sources of lesser importance.

\section{Norway}

HCB: Emissions from residential combustion of wood and combustion of hazardous waste seem to be the main sources in Norway. The metal industry is indicated to be a source of some importance. Energy production from waste, combustion of municipal waste and road transport are indicated to be sources of lesser importance.

PCBs: Road transport and petroleum refineries seem to be the main sources to PCB emissions. The mineral industry, combustion of hazardous waste and the metal industry are indicated to sources of some importance. Residential combustion and energy production seem to represent minor sources.

\section{Sweden}

HCB: Residential combustion of wood and combustion of hazardous waste seem to comprise the main sources of emission of HCB in Sweden. Other sources that may be important are the metal industry, combustion of municipal waste and energy production from waste. Energy production from wood and road transport, seem to be lesser sources. 
PCBs: Road transport and petroleum refineries seem to be the main sources to PCB emissions. Emissions from the metal industry, energy production of wood and coal, combustion of hazardous waste and the mineral industry may also be of importance. Residential combustion of wood, energy production from waste and combustion of municipal waste are indicated to be source of lesser importance in Sweden.

\subsubsection{Release to water and soil}

Output from wastewater treatment plants in terms of effluents to surface waters and sludge for final disposal, e.g. as fertilizer, is of significance. There seems to be a risk of increased effluent concentrations due to the presence of dust particles from wet scrubbing processes. However, information is very limited and no effort to derive data from separate industries has been performed. Releases with effluent wastewater are expected to be of minor importance compared to sludge. Measured concentrations in sludge are still indicated to be low compared to e.g. solid residues from combustion processes (see below).

\subsection{Data gaps and need for further investigations}

\subsubsection{Emission factors - waste combustion}

In general the reported emission factors for PCB and HCB seem high, especially for PCB. Regarding combustion processes involving waste, the emission factors are highly variable depending on the types of waste in question. The relative importance of flue-gas cleaning techniques contra the e.g. chlorine and organic content of feed material needs to be reflected in the emission factors used or to be documented as of minor importance. The selection of a fuel independent emission factor as in the Finnish inventory is only valid assuming the governing factor for the size of the emission factor is the technical aspects; i.e. air pollution control devices (APCDs). There seems to be a need for deriving the relationship between APCD and other technological aspects for waste types and resulting emission factors; e.g. in accordance with the new reporting obligations of waste types (EU Regulation on waste R and D categories, 2007).

\subsubsection{Emission factors - In general}

As may be observed from Annex 1 to 6, high uncertainty exists with regard to emission factors. More studies and selection and derivation of the most suitable emission factors reflecting technological developments seem to be required to obtain more realistic emission factors, especially for PCB. This need is exemplified by the fact that some studies show that 
HCB is in general emitted in concentration levels that exceed those of PCB, but this is not reflected in the results of this study. HCB emission factors were chosen from the Finnish inventory report on HCB where possible (Saarinen et al, 2007).

\subsubsection{Release factors into mass flows}

There may be a problem regarding re-emission of unintentional POPs and, therefore, further knowledge needs to be obtained, and the IPPC BREF documents adjusted, in relation to treatment technologies for residue products such as fly ash from municipal waste incineration (e.g. Misaka et al., 2006) as well as wastewater treatment technologies (e.g. Nollet et al., 2003). Effective control of the wastewater treatment technologies and the capability to deal with dissolved and particle-bound influent PCB and HCB at trace levels are required to secure the maximum possible decrease in the concentration levels in effluent water (e.g. Bergquist et al, 2006).

Regarding mass flows of HCB and PCB from sources to final disposal or recovery process, in particular demolition and EEE waste, shredder and waste oils may represent important unintentional sources. Data regarding mass flows and content of unintentional POP's should be further addressed with the purpose of verifying proper treatment technologies and practices and to document that hazardous residues are combusted at HWI plants with high destruction efficiencies. Such information is needed for the verification of the effectiveness of the relevant directives (Directive 2000/53/EC on end-of life vehicles, Directive 75/439/EEC on the disposal of waste oils, Directive 2002/96/EC on waste electrical and electronic equipment, Directive 2002/95/EC on the restriction of the use of certain hazardous substances in electrical and electronic equipment).

Measures controlling the final disposal or recovery of material from end-of-life products could be relevant in order to produce available data for evaluation of secondary sources. Information on mass flows within specialized recycling industries should be evaluated and emission factors for specific processes at e.g. shredder plants would need to be derived in order to improve future assessments of emissions. Activity data on the final disposal categories for residue products and quality assessment of material to prohibit circulation of impurities in recycling is needed. Control monitoring could be relevant in relation to ensuring a high reduction and destruction efficiency and corresponding correction of emission factors.

Finally, import and export of residue products and waste for treatment at specialized high technology plants needs to be addressed in relation to future unintentional releases of HCP and PCBs. 


\section{References}

Abad, E., Martinez, K., Caixach, J. and Rivera, J. (2004) Polychlorinated Dibenzo-p-dioxin/ Polychlorinated Dibenzofuran Releases into the Atmosphere from the Use of Secondary Fuels in Cement Kilns during Clinker Formation. Environ. Sci. Technol. 2004, 38, 4734-4738

AEA Technology Environment (2001). Determination of Atmospheric Pollutant Emission Factors at a Small Coal-fired heating boiler

AEA Technology Environment (2001). Determination of Atmospheric Pollutant Emission Factors at a Small Industrial Wood-Burning Furnace

AEA Technology (2003). Emission factors programme Task 7 - Review of Residential and small-scale commercial combustion sources. Report to the Department for Environment, Food and Rual Affairs; the National Assembly of Wales: the Scottish Executive; and the Department of Environment in the Northern Ireland.

http://www.airquality.co.uk/archive/reports /cat08/0407081208_Task7_cumbustion_re port_issue1.pdf

Alcock, R.E., Gemmill,R. and Jones, K. (1999). Improvements to the UK PCDD/F and PCB atmospheric emission inventory following an emissions measurement programme. Chemosphere, 38, 759-770.

Almqvist, H. and Hanæus, J. (2006). Organic Hazardous Substances in Graywater from Swedish Households. J. Envir. Engrg., Volume 132, Issue 8, pp. 901-908.

Andersson, M., Volden, T., Haugland, T., and Ottesen, R.T. (2002). PCB i yttervegger i hus fra Bergen og I uteområderne rundt om bygningerne. NGUrapport 2002. 102. 16 p.

Andersson, M., Ottesen, R.T. and Volden, T. (2003). PCB I barns lekemiljø i Bergen. NGU-rapport 2003. 58. 22 p. ISSN 0800-3416.

Andrijewski, M. et al. (2004). Enabling activities to facilitate early action on the implementation of the Stockholm Convention on Persistent Organic Pollutants
(POPs). Poland, National Implementation Plan for the Stockholm Convention, Warsaw 2004. http://ks.ios.edu.pl/gef/ doc/NIP-Poland-eng.pdf

Australian Government (2004). Department of the Environment and Heritage. National Pollutant Inventory. Emissions Estimation Technique Manual for Glass and Glass Fibre Manufacturing.Version 2.0.

http://www.npi.gov.au/handbooks/appro ved_handbooks/pubs/fglass.pdf

Avfall Sverige (2007). Svensk Avfallshantering 2007. http://www.avfallsverige.se/ $\mathrm{m} 4 \mathrm{n}$ ?oid=848\&_locale $=1$

Baggio, P., Baratieri, M., Gasparella , A., Longo, G.A. (2008). Energy and environmental analysis of an innovative system based on municipal solid waste (MSW) pyrolysis and combined cycle. Applied Thermal Engineering 28,136-144.

Bailey, R.E. (2001): Global Emissions of Hexachlorobenzene. Chemosphere 43, 167-182

Barber, J., Sweetman, A., Jones, K. (2005). Hexachlorobenzene - Sources, environmental fate and risk characterisation.Dossier Science publication from Eurochlor. http://www.eurochlor.org /upload/documents/document187.pdf

Basel Convention on the Control of Transboundary Movements of Hazardous'Wastes and Their Disposal (2005). http://www.basel.int/text/con-e-rev.pdf Basel (2007a). Technical guidelines on the environmentally sound management of wastes containing or contaminated with unintentionally produced polychlorinated dibenzo-p-dioxins (PCDDs), polychlorinated dibenzofurans (PCDFs), hexachlorobenzene (HCB) or polychlorinated biphenyls (PCBs). http://www.basel.int/ pub/techguid/tg-dioxfuran.pdf

Basel (2007b). Updated technical guidelines for the environmentally sound management of wastes consisting of, containing or contaminated with polychlorinated biphenyls (PCBs), polychlorinated terphenyls (PCTs) or polybrominated biphenyls (PBBs). http://www.basel.int/ pub/techguid/tg-PCBs.pdf 
BAT draft document. Cement Kilns firing Hazardous Waste - Draft 15. April 2006. http://www.pops.int/documents/batbep_ad vance/intersessional_work/ Book\%206\%20Cement\%20Kilns.doc\#_T oc132899368

BAT draft document. Section V guidance/guidelines by source category: Annex C part ii source categories.

http://www.pops.int/documents/meeting s/bat_bep/3rd_session/EGB_3_2/secsVp artIIsources.doc

Belgiorno, V. De Feo, G., Della Rocca, C. and Napoli, R.M.A. (2003). Energy from gasification of solid wastes. Waste Management 23, 1-15.

Berdowski, J.J.M., Baas, J., Bloos, J.P.J., Visschedijk, A.J.H., Zandveld, P.Y.J. (1997) The European Atmospheric Emission Inventory for Heavy Metals and Persistent Organic Pollutants. Umweltforschungsplan des Bundesministers fur Umwelt, Naturschutz und Reaktorsicherheit. Luftreinhaltung. Forschungbericht 10402 672/03. TNO, Apeldoorn, The Netherlands.

Bergquist, P-A, Tysklind, M., Marklund, S, Åberg, A., Sundquist, K., Näslund, M., Rosén, I., Tsytsik, P., Malmström, H., Cato, I. 2005.Kartläggning av utsläppskällor för oavsiktligt bildade ämnen: PCDD/F, PCB och HCB. Report from Naturvårdsverket.

http://www.chem.umu.se/dep/envichem/fors kning/publikationer/rapporter/NV\%20kartl \%E4ggning\%20report\%2020050317b.pdf

Bergqvist, P.-A., Augulytè, L. and Jurjonienė, V. (2006). PAH and PCB removal efficiencies in Umeå (Sweden) and Šiauliai (Lithuania) municipal wastewater treatment plants. Water, Air, \& Soil Pollution, 175, 291-303.

BiPRO (2005). Study to facilitate the implementation of certain waste related provisions of the Regulation on Persistent Organic Pollutants (POPs). Prepared for the European Commission, Brussels. http:// ec.europa.eu/environment/waste/studies/pd f/pop_waste_executive_summary.pdf BiPRO (2006). Study on "Identification, assessment and prioritisation of EU measures to reduce releases of unintentionally produced/releases persistent organic pollutants”. http://ec.europa.eu/ environment/dioxin/pdf/report.pdf

Blumenstock, M., Zimmermann, R., Schramm, K.-W. and Kettrup, A. (2000). Influence of combustion condi- tions on the PCDD/F-, PCB-, PCBz- and $\mathrm{PAH}$-concentrations in the postcombustion chamber of a waste incineration pilot plant. Chemosphere 40, 987993.

Buekens, A., Stieglitz, L.,Hell, K., Huang, H., Segers, P.(2001). Dioxins from thermal and metallurgical processes: recent studies for the iron and steel industry. Chemosphere, 42, 729-735.

Butler, D., Docx, P., Hession, M., Makropoulos, C., McMullen, M., Nieuwenhuijsen, M., Pitman, A., Rautiu, R., Sawyer, R., Smith, S., White, D., Wilderer, P., Paris, S., Marani, D., Braguglia, C., Palerm, J. (2001). Pollutants in Urban Waste Water and Sewage Sludge. For DG Environment by ICON. http://ec.europa.eu/ environment/waste/sludge/pdf/ sludge_pollutants.pdf

California Environmental Protection Agency (2006). Evaluation of Shredder Residue as Cement Manufacturing Feedstock.

Capuano, F., Cavalchi, B., Martinelli, G., Pecchini, G., Renna, E., Scaroni, I., Bertacchi, M. and Bigliardi, G. (2005). Environmental prospection for PCDD/PCDF, PAH, PCB and heavy metals around the incinerator power plant of Reggio Emilia town (Northern Italy) and surrounding main roads. Chemosphere 58 (2005) 1563-1569.

CemMiljø A/S, Sølystvej 18, 9100 Aalborg. http://www.cemmiljoe.com/ default.aspx?m=2\&i=70

Clean Production Action, 2006. http://www.cleanprodution.org/LCA/ denmark.htm

Cohen et al. (1995) Quantitative Estimation of the Entry of Dioxins, Furans, and Hexachlorobenzene into the Great Lakes from Airborne and Waterborne Sources, Center for the Biology of Natural Systems, Flushing, NY.

COM (2001) Commission Regulation no. 466/2001 of 8 March 2001 setting maximum levels for certain contaminants in foodstuffs as regards dioxins and dioxin-like PCBs, as last amended by Commission Regulation (EC) no. 199/2006 of 3 February 2006.

COM (2005). Proposal for a directive of the European parliament and of the council on waste. Brussels, 21.12.2005 COM(2005) 667 final. http://eurlex.europa.eu/LexUriServ/LexUriServ.do ?uri=COM:2005:0667:FIN:EN:PDF 
COM (2006). Commission Regulation no. 199/2006 of 3 February 2006

COM (2007a) GREEN PAPER, On better ship dismantling. Brussels, 22.5.2007.

http://ec.europa.eu/environment/waste/s hips/pdf/com_2007_269_en.pdf

COM (2007b). Communication from the commission to the council and the European parliament on the Interpretative Communication on waste and byproducts. Brussels, 21.2.2007, $\operatorname{COM}(2007) 59$ final. http://eurlex.europa.eu/LexUriServ/LexUriServ.d o?uri=COM:2007:0059:FIN:EN:PDF

COM (2007c) Commission Regulation (EC) No 1379/2007 of 26 November 2007 amending Annexes IA, IB, VII and VIII of Regulation (EC) No 1013/2006 of the European Parliament and of the Council on shipments of waste, for the purposes of taking account of technical progress and changes agreed under the Basel Convention. http://faolex.fao.org/ docs/pdf/eur75646.pdf

Cooper, D.A. (2004). HCB, PCB, PCDD and PCDF emissions from ships. ReportIVL Svenska Miljöinstitutet AB. http:// www.ivl.se/rapporter/pdf/B1620.pdf

Cooper, D.A. (2005). HCB, PCB, PCDD and PCDF emissions from ships. Atmospheric Environment 39, 4901-4912.

Danish Crown. Grønt regnskab Danish Crown 2005/06. http://www.datagraf.dk /pageviewerx/data/Danishcrown/Generel le/Regenskab\%202005-06/pdf/pdf.pdf

Danish Government (2005) Affaldsstrategi 2005-2008. http://www2.mst.dk/udgiv/ Publikationer/2003/87-7972-971-1/ pdf/87-7972-973-8.pdf

DEFRA (2006). A review of the current source inventories for dioxin and dioxinlike PCBs for air, soil and water with view to updating emission factors/ estimates and inclusion of new sources. http://www.defra.gov.uk/science/project _data/DocumentLibrary/CB01068/CB01 068_3412_FRP.pdf

DEPA (1999) Economic Instruments In Environmental Protection in Denmark, Danish Environmental Protection Agency, Ministry of Environment and Energy, 1999 pp76-78, www.mst.dk DEPA (2000a). Livscyklus-screening af renseteknologier for fiskeindustrien. Arbejdsrapport fra Miljøstyrelsen Nr. 18 2000. http://www.miljøstyrelsen.dk /udgiv/publikationer/2000/87-7944240-4/pdf/87-7944-241-2.pdf
DEPA (2000b). Central oparbejdning af galvanisk affald. Miljøprojekt Nr. 55. http://glwww.mst.dk/udgiv/publikationer/ 2000/87-7944-227-7/pdf/87-7944-2285.pdf

DEPA (2003). Spildevandsslam fra kommunale og private renseanlæg i 2000 og 2001. Orientering fra Miljøstyrelsen nr. 9. http://www2.mst.dk/common/Udgivram me/Frame.asp?pg=http://www2.mst.dk/ Udgiv/publikationer/2003/87-7614005-9/html/default.htm

DEPA (2006a). National Implementation Plan - Stockholm Conventionen on Persistent Organic Pollutants. http://www2.mst.dk/common/Udgivram me/Frame.asp?pg=http://www2.mst.dk/ Udgiv/publications/2006/87-7052-0674/html/default_eng.htm

DEPA (2006b). Affaldsstatistik 2005. Orientering fra Miljøstyrelsen Nr. 6., Miljøministeriet. http://www2.mst.dk/ udgiv/publikationer/2006/87-7052-2847/pdf/87-7052-285-5.pdf

DEPA (2007).Bekæmpelsesmiddelstatistik 2006. Orientering fra Miljøstyrelsen Nr. 5 2007. http://www2.mst.dk/ common/Udgivramme/Frame.asp?pg= http://www2.mst.dk/Udgiv/publikationer/2 007/978-87-7052-492-6/html/default.htm

Duiser J.A., and Veldt C. (1989) Emissions into the Atmosphere of PAHs, PCBs, Lindane and HCB in Europe. Technical Report No. 89-036, TNO Division of Technology for Society, Apeldoorn.

Dyke, P.H. (2002). PCB and PAH Releases from Incineration and Power Generation Processes. R\&D Technical Report P4-052. Environment Agency, Bristol, UK. http://www.pops.int/documents/ guidance/NIPsFinal/techrep.pdf

EEA (2006). EMEP/CORINAIR Emission Inventory Guidebook - 2006. http://reports.eea.europa.eu/EMEPCORI NAIR4/en/page002.html

Enviros Consulting Limited (2006). Department for Environment, Food and Rural Affairs. Emissions Of Dioxins And Dioxin-Like Polychlorinated Biphenyls From Domestic Sources. http://www. defra.gov.uk/environment/chemicals/pdf/ dioxinsdomestic-final0605.pdf

EPRI, report on PCB in fly ash (1998)

E-PRTR Regulation: Regulation (EC) No 166/2006 of the European Parliament and of the Council concerning the establishment of a European Pollutant Release and Transfer Register and amending 
Council Directives 91/689/EEC and 96/61/EC.

http://eper.cec.eu.int/eper/documents/EPRTR\%20Regulation.pdf

European Association of Mining Industries. http://www.euromines.org/

European Commission, Brussels (1999), Landfill of Waste Directive, Council Directive 1999/31/EC.

European Commission, Belgium (1999). End of life Vehicle Directive, Council Directive 2000/53/EC.

European Commission (2006). Guidance Document for the implementation of the European PRTR http://ec.europa.eu/ environment/ippc/eper/pdf/en_prtr.pdf

European Commission (2004) Life Cycle Assessment of PVC and of principal competing materials, Commissioned by the European Commission, July 2004. http://ec.europa.eu/enterprise/chemicals/ sustdev/pvc-final_report_lca.pdf

European PRTR Homepage on Releases from Diffuse Sources. http://www.bipro.de/_prtr/index.htm EU Directive 2000/76/EC on Incineration of Waste regulates Co incineration of Hazardous Waste in Cement Kilns.

EU directive 2002/96/EC on waste treatment of waste from electric and electrical equipment (WEEE).

Directive 86/278/EEC of 12 June 1986 on the protection of the environment, and in particular of the soil, when sewage sludge is used in agriculture. http://eurlex.europa.eu/LexUriServ/LexUriServ.d o?uri=CELEX:31986L0278:EN:NOT

Directive 75/439/EEC on the disposal of waste oils

Directive 2002/95/EC on the restriction of the use of certain hazardous substances in electrical and electronic equipment

Directive 2000/76/EC on Incineration of Waste regulates Co incineration of Hazardous Waste in Cement Kilns

Directive 2002/96/EC on waste treatment of waste from electric and electrical equipment (WEEE)

European Waste Strategy (2005). http://ec.europa.eu/environment/waste/st rategy.htm

EUROSTAT (2003).Iron and Steel Yearly statistics. Concluding edition - Data 1993-2002.

http://epp.eurostat.ec.europa.eu/cache/IT Y_OFFPUB/KS-BL-03-001-3A/EN/KSBL-03-001-3A-EN.PDF
Finnish Environmental Administration (2006).National Implementation Plan for the Stockholm

Convention on Persistent Organic Pollutants. http://www.ymparisto.fi/ download.asp?contentid=51364\&lan=fi

Frank J. Castaldi, P.E. (2004). Tank-based bioremediation of petroleum waste sludges. Environmental Progress, 22, 25-36.

Gäbel, K., Tillman, A.-M. (*2005). Simulating operational alternatives for future cement production. Journal of Cleaner Production, 13, 1246-1257.

Gendebien, A., Leavens, A., Blackmore, K., Godley, A., Lewin, K., Whiting, K.J., Davis, R. Giegrich, J., Fehrenbach H., Gromke, U., del Bufalo, N. and Hogg, D. (2003) Refuse derived fuel, current practice and perspectives (B43040/2000/306517/MAR/E3). FINAL REPORT, EUROPEAN COMMISSION - DIRECTORATE GENERAL ENVIRONMENT http://ec.europa.eu/ environment/waste/studies/pdf/rdf.pdf

Guidelines on BAT and Guidance on BEP (2006). Revised draft guidelines on best available techniques and provisional guidance on best environmental practices relevant to article 5 and annex $\mathrm{C}$ of the Stockholm Convention on persistent organic pollutants. Geneva, Switzerland December 2006.http://www.pops.int/ documents/guidance/batbep/ batbepguide_en.pdf

Gullett, B.K., Touati,A. and Hays, M.D.(2003). PCDD/F, PCB, HxCB, $\mathrm{PAH}$, and PM Emission Factors for Fireplace and Woodstove Combustion in the San Franscisco Bay Region. Environ. Sci. Technol. 37, 1758-1765

Hedman, B., Näslund,M. and Marklund, S. (2006). Emission of PCDD/F, PCB, and HCB from Combustion of Firewood and Pellets in Residential Stoves and Boilers. Environ. Sci. Technol., 40 (16), 4968 4975, 2006. http://pubs.acs.org/cgibin/article.cgi/esthag/2006/40/i16/pdf/es 0524189.pdf

Hedman, B, Näslund, M.,Nilsson, C. and Marklund, S. (2005). Emissions of Polychlorinated Dibenzodioxins and Dibenzofurans and Polychlorinated Biphenyls from Uncontrolled Burning of Garden and Domestic Waste (Backyard Burning). Environ. Sci. Technol., 39, 8790-8796.

Henriksen, T.C., Illerup, J.B. and Nilesen, O.-K. (2006). Dioxin air emission inventory 1990-2004. National Environmental 
Research Institute, Denmark. 90 pp. NERI Technical report no 602. http://www.dmu.dk/Pub/FR602.pdf Herrick, R.F., Lefkowitz, D.J. and Weymouth, G.A. (2007). Soil Contamination from PCB-Containing Buildings. Environmental Health Perspectives Volume 115, Number 2, February 2007

Institut for Miljøvurdering (2004). Nyttiggørelse af brændbart affald. Velfærdsøkonomisk analyse af medforbrænding ved cementproduktion på Aalborg Portland A/S. http://www.cemmiljoe.com/ media/pdf_files/

nyttiggoerelse_af_braendbart_affald.pdf

IPPC (2007). Best Available Techniques Reference Document (BREF) in the Cement and Lime Manufacturing Industries (CLMI), Draft document 2007. http://eippcb.jrc.es/pages/FActivities.htm IPPC (2006). Best Available Techniques Reference Document (BREF) for Waste Incineration (WI), August 2006. http://eippcb.jrc.es/pages/FActivities.htm IPPC (2001). Best Available Techniques Reference Document (BREF) in the Glass Manufacturing Industry (GMI), December 2001.

http://eippcb.jrc.es/pages/FActivities.htm IPPC (2001). Best Available Techniques Reference Document (BREF) in the Pulp and Paper (PPI), December 2001. http://eippcb.jrc.es/pages/FActivities.htm IPPC (2001). Best Available Techniques Reference Document (BREF) on the Production of Iron and Steel (IS) December 2001. http://eippcb.jrc.es/pages/FActivities.htm IPPC (2001). Best Available Techniques Reference Document (BREF) in the Non Ferrous Metals Industries (NFMI) December 2001. http://eippcb.jrc.es/ pages/FActivities.htm

IPPC (2001). Best Available Techniques Reference Document (BREF) in the Ferrous Metals Processing Industry (FMPI) December 2001. http://eippcb.jrc.es/ pages/FActivities.htm

IPPC (2006). Best Available Techniques Reference Document (BREF) for the manufacture of Organic Fine Chemicals (OFC), August 2006. http://eippcb.jrc.es /pages/FActivities.htm

IPPC (2003). Best Available Techniques Reference Document (BREF) for the manufacture of Large Volume Organic Chemicals (LVOC), February 2003.
http://eippcb.jrc.es/pages/FActivities.htm IPPC (2007). Best Available Techniques Reference Document (BREF) for the production of speciality inorganic chemicals (SIC), August 2007. http://eippcb.jrc.es/pages/FActivities.htm IPPC (2004). Best Available Techniques Reference Document (BREF) for the management of tailings and waste-rock in mining activities (MTWR), July 2004. http://eippcb.jrc.es/pages/FActivities.htm IPPC (2001). Best Available Techniques Reference Document (BREF) in the Chlor-Alkali Manufacturing industry (CAMI), December 2001. http://eippcb.jrc.es/pages/FActivities.htm IPPC (2003). Available Techniques Reference Document (BREF) in the Textile Industry (TI), July 2003.

http://eippcb.jrc.es/pages/FActivities.htm IPPC (2003). Available Techniques Reference Document (BREF) in the Mineral Oil and Gas Refineries (MOGR), February 2003. http://eippcb.jrc.es/pages/FActivities.htm IPPC (2003). Available Techniques Reference Document (BREF) on techniques in the smitheries and foundries industry (TSFI), February 2003.

http://eippcb.jrc.es/pages/FActivities.htm IPPC (2003). Available Techniques Reference Document (BREF) on techniques Common Waste Water and Waste Gas Treatment / Management Systems in the Chemical Sector (CWW), February 2003. http://eippcb.jrc.es/pages/FActivities.htm IPPC (2006). Available Techniques Reference Document (BREF) on techniques for Large combustion plants (LCP), July 2006. http://eippcb.jrc.es/pages/FActivities.htm IPPC (2005). Available Techniques Reference Document (BREF) on techniques in the Slaughterhouses and Animal Byproducts Industries (SABI), May 2005. http://eippcb.jrc.es/pages/FActivities.htm IPPC (2007). Available Techniques Reference Document (BREF) on techniques in the Ceramic Manufacturing Industry (CMI), August 2007. http://eippcb.jrc.es /pages/FActivities.htm

IPPC (2006). Available Techniques Reference Document (BREF) on techniques for the Waste Treatment Industries (WTI), August 2006. http://eippcb.jrc.es/pages/FActivities.htm Information System for Waste and Recycling (EN) ISAG, Informationssystem for Affald og Genanvendelse (DK). 
http://www.statistikbanken.dk/statbank5 a/SelectVarVal/Define.asp?Maintable= AFF4\&PLanguage $=1$

Ishikawa, Y, Noma, Y., Yamamoto, T., Mori, Y., Sakai, S. (2007). PCB decomposition and formation in thermal treatment plant equipment, Chemosphere 67, 1383-1393.

Ito, R., Dodbiba, G., Fujita, T., Ahn, J.W. (2007). Removal of insoluble chloride from bottom ash for recycling. Waste Management, in press

Jacquinot, B., Hjelmer, O., Vehlow, J.(2000). The influence of PVC on the quantity and hazardousness of flue gas residues from incineration. Bertin Technologies, B4-3040/98/000101/MAR/E3

Kakareka, S. and Kakharchyk, T. (2002) Expert estimates of PCDD/F and PCB Emissions for some European countries. MSC-E Technical note 2/2002. http://www.vak.lv/publications/minskas _pet.pdf

Karstensen K. H. 2006. Formation and Release of POPs in the Cement Industry. Second edition, January 2006. World Business Council for Sustainable Development/SINTEF

Karstensen, K.H. (2007). Formation, release and control of dioxins in cement kilns, Chemosphere in press.

Kikuchi, R., Kukacka, J., Raschman, R. (2007). Grouping of mixed waste plastics according to chlorine content. Separation and Purification Technology 61, 75-81.

Kenichi Y., Takasi I., Yoshio Y., Yoshinori T. and Kosaku O. (2002) Chemosphere 46, 1309-1319.

Kim, S.-C., Choe, S.-H., Na, J.-G., Hwang, S.-R., Lee, Z.-H., Chang, J.-Y., Cho, H.-J.(2004). Correlations of emission concentrations among PCDDs/PCDFs, co-planar PCBs and HCB from major thermal stationary sources. ORGANOHALOGEN COMPOUNDS, 66, 941-945.

Krogh, H. (1999) SBI-meddelelse 122: Problematiske stoffer i byggevarer. Statens Byggeforskningsinstitut. ISBN 87563-1027-7.

Kurt-Karakus, P. and Jones, K.C. (2006). Microcosm studies on the air-soil exchange of hexachlorobenzene and polychlorinated biphenyls. J. Environ. Monit., 2006, 8, 1227 - 1234

Kuusisto, S., Lindroos, O., Rantio, T., Priha, E. and Tuhkanen, T.(2007). PCB contaminated dust on indoor surfaces Health risks and acceptable surface concentrations in residential and occupational settings. Chemosphere 67 (2007) 1194-1201.

Leclerc, D., Dupo, W.L. and Vessey, M.(2006). Effects of combustion and operating conditions on PCDD/PCDF emissions from power boilers burning salt-laden wood waste. Chemosphere 63, 676-689.

Lemieux, P.M., B.K. Gullett, C.C. Lutes, C.K. Winterrowd, and D.L. Winters (2002) "Variables Affecting Emissions of PCDDs/Fs from Uncontrolled Combustion of Household Waste in Barrels, Journal of the Air and Waste Management Association

Lemieux, P.M. (2002) "Emissions of Organic Air Toxics from open Burning” EPA-600/R-02-076.

Lönnermark, A (2007). Emissions from landfill fires and fires in storage of waste. Kalmar ECO-TECH '07 and The Second Baltic Symposium on Environmental Chemistry KALMAR, SWEDEN, November 26-28, 2007.

Lönnermark, A., Blomquist, P., Marklund, S. (2008).Emissions from simulated deep-seated fires in domestic waste. Chemosphere 70, 626-639.

Maag, J. and Lassen, C. PCB i apparater i Danmark. Arbejdsrapport fra Miljøstyrelsen Nr. 15 2000. http://www2.mst.dk/ udgiv/Publikationer/2000/87-7944-1661/pdf/87-7944-168-8.PDF

Malkow, T. (2004) Novel and innovative pyrolysis and gasification technologies for energy efficient and environmentally sound MSW disposal. Waste Management 24, 53-79.

Meijer, S.N., Ockenden, W.A., Sweetman, A., Breivik, K., Grimalt, J.O. and Jones, K.C. (2003). Global distribution and budget of PCBs and HCB in background surface soils: Implications for sources and environemtnal processes. Environmental Science and Technology, 37, 667-672.

Misaka, Y., Yamanaka, K., Takeuchi, K., Sawabe, K. and Shobatake, K. (2006). Removal of PCDDs/DFs and dl-PCBs in MWI fly ash by heating under vacuum. Chemosphere 64, 619-627.

Mobbs, M. (2005). Fossil Fuel Fired Utility and Industrial Boilers. Australia according to discussions in Geneva at EG in 2005 and comments submitted to the 
Stockholm Secretariat.

http://www.pops.int/documents/batbep_ advance/intersessional_work/ Book\%2011\%20fossil\%20fueled\%20fir ed\%20utilities.doc

Naturvårdsverket 1999. Metodik för inventering av Förorenade områden.

Naturvårdsverket (2005). Kartläggning av utsläposkällor för oavsiktligt bildade ämnen:PCDD/F, PCB och HCB. Rapport MK2005:01, Miljökemi, Kemiske institutionen, Umeå universitet.

Naturvårdsverket (2005). Survey of sources of unintentionally produced substances. A report to the Swedish Government, Report 5503.

Nerpin, L., Nordell, O., Nielsen, J.B., Hein, M., Carlsson, C., Bjerre, F. og Brøns-Hansen, J. (2005). Miljøfarlige stoffer i Øresund, en oversigt - Miljögifter i Öresund, en översikt. Øresundsvandsamarbejdet - Öresundsvattensamarbetet. www.oresundsvand.dk.

Nordisk Ministerråd (2007). Bedste tillgængelige teknikker (BAT) i autoværksteder. TemaNord 2007:544. ISBN 97892-893-1516-6

Nollet, H., Roels, M., Lutgen, P., Van der Meeren, P., Verstraete, W. (2003). Removal of PCBs from wastewater using fly ash. Chemosphere 53 (2003) 655-665

Norwegian Ministry of Environment (2006).NORWEGIAN IMPLEMENTATION PLAN FOR THE STOCKHOLM CONVENTION ON PERSISTENT ORGANIC POLLUTANTS (POPs)

http://www.pops.int/documents/impleme ntation/nips/submissions/Norway.pdf

Nourreddine, M. (2007). Recycling of auto shredder residue. Journal of Hazardous Materials, A139, 481-490.

Ottesen, R.T., Volden, T., Finne, T.E. and Alexander, J. (1999). Undersøkelse av polyklorerte biphenyler (PCB) i jorden i skolegården ved Skjold skole. NGUrapport 99.049. 11s.

Öberg, T. (1996). Replacement of PCB (polychlorinated biphenyls) and HCB (hexachlorobenzene) - the Swedish experience. In "Alternatives to persistent organic pollutants", report 4/96, Swedish National Chemical Inspectorate. http://www.tomasoberg.com/pdf/pcb.pdf Pacyna, J.M., Breivik, K., Münch, J. and Fudala, J. (2003). European atmospheric emissions of selected persistent organic pollutants, 1970-1995, Atmospheric Environment 37

Pegg, M.J., Amyotte, P. R., Fels, M., Cumming, C.C.R and Poushay, J.C. (2007). An assessment of the use of tires as an alternative fuel. Department of Process Engineering and Applied Science

Faculty of Engineering, Dalhousie University, Canada.

http://www.gov.ns.ca/enla/waste/docs/Ti reUseAlternativeFuelAssessment.pdf

PRODCOM data reporting scheme. http://www.eds-destatis.de/en/method/ download/ prodcom2007_EN.pdf PRTR-protocol. http://www.unece.org/env/pp/prtr/docs/P RTR_Protocol_e.pdf

Pandelova, M., Lenoir, D., Schramm, K.W. (2006). Correlation between PCDD/F, PCB and PCBz in coal/waste combustion. Influence of various inhibitors. Chemosphere 62 (2006) 1196-1205

Ratafia-Brown, J., Manfredo, L., Hoffmann,J., Ramezan, M. (2002). Major Environmental Aspects of Gasificationbased power generation technologies. U.S. Department of Energy. Office of fossil energy. National Energy Technology Laboratory. December 2002.

Ragunathan, K., Gullett, B., 1996, Role of Sulfur in Reducing PCDD and PCDF Formation, Environ. Sci. Technol., 30 (6), 1827-1834.

Ref lab (2006), Vurdering af PCB emissionsgrænseværdien. Rapport nr. 34. www.ref-lab.dk

Ref lab (2007), Vurdering af dioxinemission fra affaldsforbrænding 1999-06. Rapport nr. 43. www.ref-lab.dk

RVF - The Swedish Association of Waste Management (2006).Swedish waste management. http://www.avfallsverige.se

Saarinen, K., Kindbom, K., Aasestad, K., Illerup, J.B. and Hallsdottir (2007). Review, improvement and harmonization of the Nordic Air Emission Inventories by cooperation in the NAEEG group. Norden. Saarinen, K., Lindh, P., Kokko, M., Mikkola-Pusa, J., Suomi, O., Nurmi, E., Mattila, S. (2007). Finnish HCB air emissions 1990-2005 to the Secretariat of the UNECE Convention on Long-Range Transboundary Air Pollution. Finnish Environmental Institute, Expert Services Department, Environmental Management Division, Air Emission team. 
http://www.ymparisto.fi/

download.asp?contentid=67644\&lan=sv

SBI (Statens byggeforskningsinstitut),

(1999). Problematiske stoffer i bygge-

varer. SBI-anvisning nr. 122.

Schwarzenegger, A. and Gorsen, M.(2006). Evaluation of Shredder Residue as Cement Manufacturing Feedstock. California Environmental Agency, Department of toxic substances control. Office of Pollution and Technology Development.

http://www.dtsc.ca.gov/TechnologyDev elopment/upload/

auto_shredder_report.pdf

Scientific Committee on Food (SCF), Health and Consumer Protection DirectorateGeneral, European Commission (Brussels). Opinion of the Scientific Committee on Food on the Risk Assessment of Dioxins and Dioxin-Like PCBs in Food. Update based on new scientific information available since the adoption of SCFopinion of November 22, 2000. Adopted on May 30, 2001. http://ec.europa.eu/food/fs/sc/scf /out90_en.pdf

SFT (2001). Åpen brenning og brenning av avfall i småovner: Veiledning for kommuner. http://www.sft.no/ miljoreferanse___35120.aspx

Sinkkonen, S., Kämäräinen, N., Paasivirta, J. and Lammib, R. (1997). PCDDs, PCDFs, PCDTs, PCBs and some other organochlorine compounds in pine needles exposed to pulp and paper mill emissions and effects of waste combustion on the concentrations. Chemosphere, 35, 2193-2202.

Sloss, L.L. and Smith, I.M. (1993). Organic Compounds from Coal Utilization. International Energy Agency Coal Resources Report IEACR/63. London.

Sloss, L.L. (2001). Organic Compounds from Coal Utilisation. International Energy Agency Coal Research, London. www.enel.it/ambiente/directory/iea_VO C_pf01-08.pdf

Speck, S., Skou Andersen, M., Nielsen, H.O., Ryelund, A., and Smith, C., 2006, The Use of Economic Instruments in Nordic and Baltic Environmental Policy 2001-2005, TemaNord 2006:525, Nordic Council of Ministers, Denmark.

Sverud, T. and Estensen, A.S.G. (2000). Identifisering, prøvetaking og analyse av fugemasse i bygninger for PCB

Rapportering av prosjekt utført i 1998 og oppfølgingsprosjekt utført i 1999.

ISBN82-91359-25-3

Stockholm Convention On Persistent

Organic Pollutants, Stockholm 2001. http://www.ipen.org/ipenweb/pops/5_1_ c.html\#top

Strufe, N., Trap, N. og Lauritzen, E.K. (2006). Kortlægning af forurenende stoffer i bygge- og anlægsaffald. Miljøprojekt Nr. 1083.

http://glwww.mst.dk/default.asp?Sub=htt p://glwww.mst.dk/udgiv/publikationer/2 001/87-7944-700-7/html/kap09.htm

Swedish chemicals inspectorate (2006). National Implementation Plan for the Stockholm Convention on Persistent Organic Pollutants for Sweden. http://www.kemi.se/upload/Trycksaker/P df/Rapporter/Rapport4_06.pdf

Swedish Environmental Protection Agency (2006). Quality Report for statistics on generation and recovery and disposal of waste in Sweden 2004 according to EU Regulation on Waste Statistics 2150/2002.

http://www.naturvardsverket.se/Docume nts/publikationer/620-5594-1.pdf

Thomas, V.M. and McCreight, C.M. (2008). Relation of chlorine, copper and sulphur to dioxin emission factors. Journal of Hazardous Materials. 2008 Feb 28;151(1):164-70. Epub 2007 May 26

Thomsen, M. \& Lyck, E. (2005): Emission of $\mathrm{CH}_{4}$ and $\mathrm{N}_{2} \mathrm{O}$ from Wastewater Treatment Plants (6B). National Environmental Research Institute. 46 pp. http://www2.dmu.dk/1_viden/2_Publikatio ner/3_arbrapporter/rapporter/AR208.pdf

Toda, E. (2005). POPs and heavy metals emission inventory of Japan. TFEIP \& ES-PREME Workshop on "Heavy Metals and POPs Emissions, Inventories and Projections”, 18-19 October 2005, Rovaniemi, Finland.

Trap, N., Lauritzen,E.K., Rydahl, T., Egebart, C.,Krogh, H., Malmgren-Hansen, B., Høeg, P., Jakobsen, J.B. and Lassen, C. (2006) Problematiske stoffer i byggeog anlægsaffald - kortlægning, prognose og bortskaffelsesmuligheder. DEPA Environment project no. 1084.

UNEP Chemicals, 1999.Guidelines for the Identification of PCBs and Materials containing PCBs. Fistt Issue. http://www.chem.unep.ch/pops/pdf/PCBi dent/pcbid1.pdf

UNEP Chemicals, 2002. PCB Transformers and Capacitors. From management to 
reclassification and disposal. First issue. http://www.chem.unep.ch/pops/pdf/PCB transcap.pdf

UNEP (2003). Guidelines on BAT and BEP for Municipal Waste Incineration. Draft. UNEP, Geneva.

www.pops.int/documents/meetings/bat_ bep/2nd_session/inf10/EGB2_INF10_m unwaste_incineration.pdf.

U.S. Geological Survey Mineral Information. http://minerals.usgs.gov/minerals/

US EPA (2000). Great Lakes Binational Toxics Strategy. Draft Report for Hexachlorobenzene (HCB): Reduction Options. http://www.epa.gov/grtlakes/bns/baphcb /HCB_rden.PDF

Van Remmen T. 1998. Evaluation of the Available Air Pollution Control Technologies for the Achievement of the MACT Requirements in the Newly Implemented New Source Performance Standards (NSPS) and Emission Guidelines (EG) for Hospital and Medi$\mathrm{cal} /$ Infectious Waste Incinerators. Waste Management 18:393-402.

Veritas (2000). ØkoBygg.Identifisering, prøvetaking og analyse av fugemasse i bygninger for PCB. Rapportering av prosjekt utført i 1998 og oppfølgingsprosjekt utført i 1999.

Vehlow, J., Bergfeldt, B. and Hunsinger, H. (2006). PCDD/F and related com- pounds in solid residues from municipal solid waste incineration - a literature review. Waste Management \& Research, 24, 404-420.

Vikelsøe, J., Thomsen, M., Carlsen, L. and Johansen, E. (2002). Persistent Organic Pollutants in Soil, Sludge and Sediment. A multianalytical Field Study of Selected Organic Chlorinated and Brominated Compounds. NERI Technical Report No. 402.

Wiberg, K., Åberg, A., McKone, T.E., Tysklind, M., Hanberg, A. and MacLeod, M. (2007). Model Selection and Evaluation for Risk Assessment of Dioxincontaminated Sites. Journal of the human environment, 36, 458-466.

http://ambio.allenpress.com/perlserv/?req uest=get-pdf\&doi=10.1579\%2F00447447\%282007\%2936\%5B458\%3AMSA EFR\%5D2.0.CO\%3B2

Yu, B.-W., Jin, G.-Z., Moon, Y.-H., Kim, M.-K., Kyoung, J.-D., Chang, Y.-S. (2006). Emission of PCDD/Fs and dioxin-like PCBs from metallurgy industries in S. Korea. Chemosphere 62, 494-501.

Zevenhoven, R., Kilpinen, P. (2001). Chapter 7 Halogens, dioxins/furans. In: CONTROL OF POLLUTANTS IN FLUE GASES AND FUEL GASES by Ron Zevenhoven \& Pia Kilpinen, ISBN 951-22-5527-8. 



\section{Annex 1. Potential sources originating from fuel consumption}

The figures provided in this annex present data and information that was available and accessible at the time the work was carried out on the report. It may be possible to attain a higher level of detail regarding feed material and plant type and size. Therefore the annex represents a screening level review of potential sources to UPOPs from the energy sector as well as fuel consumption from activities categorized as diffuse sources.

The fuel combustion data in Table 1.1 is obtained from the countries most recent submission to the UNFCCC; this for all four countries is the 2007 submission. Where possible, detailed fuel consumption data from the National Inventory Report is used, otherwise data from the CRF tables is used; data from waste incineration for Norway stems from Statistics Norway. The heating values of the fuels necessary to calculate the mass of fuels combusted are taken from the countries' National Inventory Reports, or in the case of Norway, from national expert knowledge on heating values. All submissions to the UNFCCC can be downloaded from the UNFCCC website:

- http://unfccc.int/national_reports/annex_i_ghg_inventories/national_ inventories_submissions/items/3929.php 
Table 1.1 Activity data regarding solid and liquid fuel consumption within the Energy, Industry sectors and diffuse sources [tonnes]

\begin{tabular}{|c|c|c|c|c|}
\hline \multirow[t]{7}{*}{$\begin{array}{l}\text { PRTR } \\
\text { code }\end{array}$} & IPCC code & & & \\
\hline & A. Fuel Combustion Activities & & Fuel type & \\
\hline & 1. Energy Industries & & & \\
\hline & $\begin{array}{l}\text { a. Public Electricity and Heat } \\
\text { Production }\end{array}$ & Coal & Wood & MSW \\
\hline & Denmark & 5904545 & 1358527 & 3316932 \\
\hline & Finland & 3053373 & 6995210 & 361290 \\
\hline & Norway & 47000 & 151000 & 697000 \\
\hline \multirow[t]{5}{*}{1} & Sweden & 426902 & 7659748 & 3250000 \\
\hline & $\begin{array}{l}\text { 2. Manufacturing Industries and } \\
\text { Construction }\end{array}$ & Coal & Wood & MSW \\
\hline & Denmark & 306480 & 309362 & 184000 \\
\hline & Finland & 1132549 & 13802605 & NO \\
\hline & Norway & 110200 & 548700 & 94000 \\
\hline \multirow[t]{13}{*}{2,3} & Sweden & 414223 & 4820756 & NO \\
\hline & 3. Transport & & & \\
\hline & a. Civil Aviation & Aviation Gasoline & Jet Kerosene & \\
\hline & Denmark & 2192 & 40373 & \\
\hline & Finland & 881 & 102910 & \\
\hline & Norway & 2300 & 250000 & \\
\hline & Sweden & 808 & 209340 & \\
\hline & b. Road Transportation & Gasoline & Diesel Oil & \\
\hline & Denmark & 1754524 & 2071982 & \\
\hline & Finland & 1739093 & 2013333 & \\
\hline & Norway & 1582000 & 1995000 & \\
\hline & Sweden & 3783255 & 2297562 & \\
\hline & d. Navigation & $\begin{array}{r}\text { Residual Oil } \\
\text { (Residual Fuel Oil) }\end{array}$ & Gas/Diesel Oil & Gasoline \\
\hline \multirow{20}{*}{ 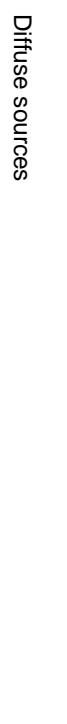 } & Denmark & 37038 & 125550 & 8983 \\
\hline & Finland & 46548 & 69860 & 51136 \\
\hline & Norway & 162000 & 354900 & NO \\
\hline & Sweden & 76345 & 71178 & 24375 \\
\hline & 4. Other Sectors & & & \\
\hline & a. Commercial//nstitutional & Coal & Wood & MSW \\
\hline & Denmark & NO & 52765 & 16440 \\
\hline & Finland & NO & 225210 & NO \\
\hline & Norway & NO & 9300 & NO \\
\hline & Sweden & NO & 93866 & NO \\
\hline & b. Residential & Coal & Wood & MSW \\
\hline & Denmark & 317 & 1875115 & NO \\
\hline & Finland & 510 & 3413445 & NO \\
\hline & Norway & 1316 & 1564000 & NO \\
\hline & Sweden & NO & 3513025 & NO \\
\hline & c. Agriculture/Forestry/Fisheries & Coal & Wood & MSW \\
\hline & Denmark & 73347 & 8337 & NO \\
\hline & Finland & 6000 & 421429 & NO \\
\hline & Norway & NO & 4300 & NO \\
\hline & Sweden & NO & 14034 & NO \\
\hline
\end{tabular}


Table 1.2 Air emission factors (EF) for HCB from fuel consuming activities

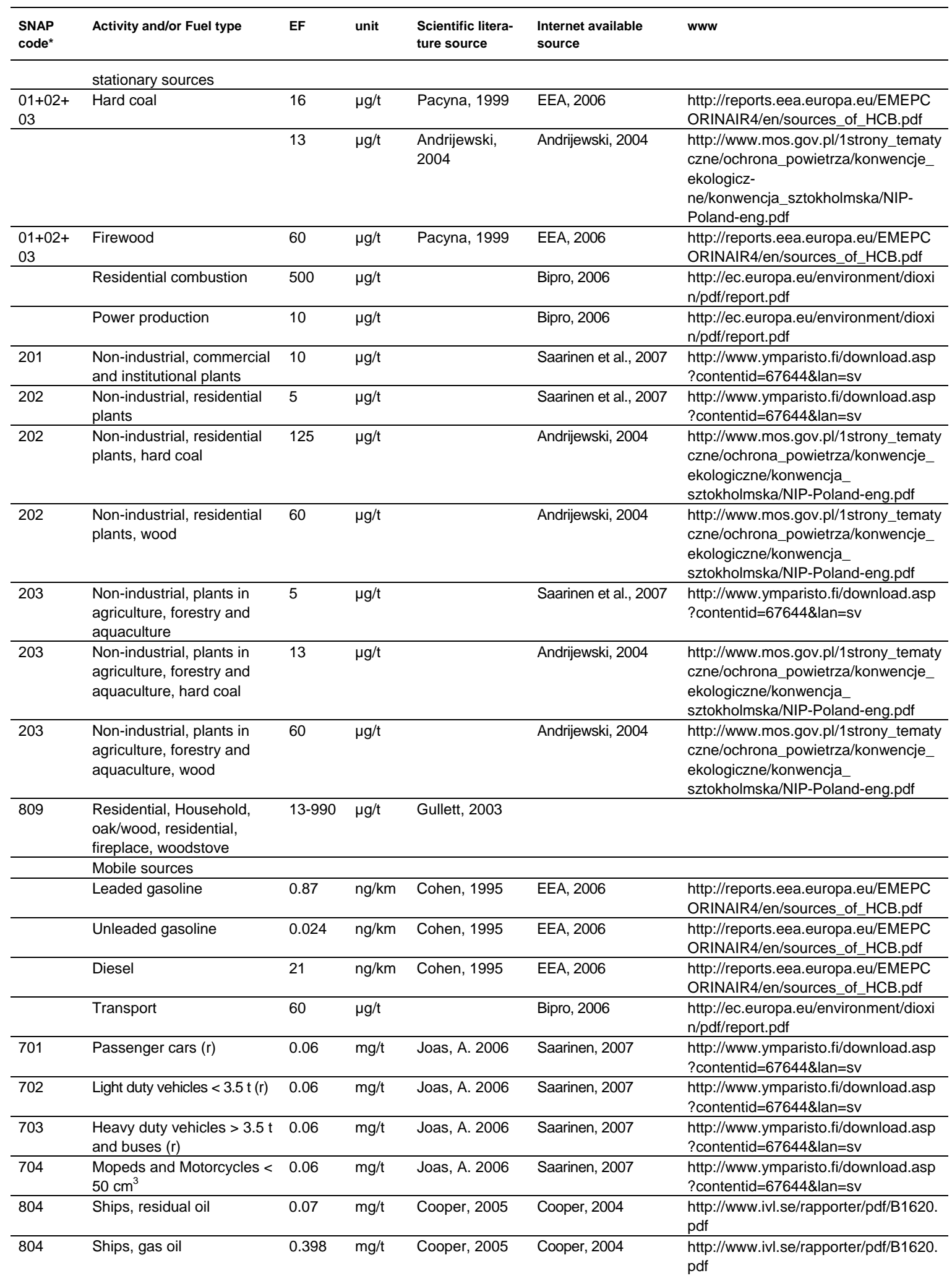


The emissions factors marked in bold have been used for estimating HCB emissions to air. Assuming that all combustion plants have adopted the best available APCDs, the emission factors provided in the Corinair guidebook $(E E A, 2006)$ may be overestimated in relation to the EF values for small combustion sources used in the Finnish IR (Saarinen et al, 2007). Adopting a precautionary or 'worst case' approach, the default EFs given in the Corinair guidebook were used for the Energy and Manufacturing Industries as well as Construction (cf. Table 1.1 in this annex).

For non-industrial commercial and institutional as well as residential energy production the EF value taken from the Finnish IR has been used in the estimated emissions given in Table 1.4. This EF is however 'fuel independent' which implies that the potential emission is equal regardless of the fuel type used for energy production. Data from Gullett et al., 2005 suggest that variations in emissions according to combustion parameters may be more important than fuel type, which may justify the selection of the Finnish lowest EF values. However, the selection of emission factors that are lower for residential combustion compared to large industrial and energy producing plant is in conflict with the fact that residential combustion generally has higher EF values due to ineffective combustion conditions (e.g. Gullet et al., 2003). 
Table 1.3 Air emission factors (EF) for PCB fuel consuming activities

\begin{tabular}{|c|c|c|c|c|c|c|}
\hline $\begin{array}{l}\text { SNAP } \\
\text { code* }^{*}\end{array}$ & Activity and/or Fuel type & EF & unit & $\begin{array}{l}\text { Scientific } \\
\text { literature source }\end{array}$ & $\begin{array}{l}\text { Internet } \\
\text { available source }\end{array}$ & www \\
\hline & \multicolumn{6}{|l|}{ Stationary sources } \\
\hline & Hard coal & 8800 & $\mu \mathrm{g} / \mathrm{t}$ & & EEA, 2006 & $\begin{array}{l}\text { http://reports.eea.europa.eu/EMEPCO } \\
\text { RINAIR4/en/sources_of_PCB.pdf }\end{array}$ \\
\hline & Firewood & 630 & $\mu \mathrm{g} / \mathrm{t}$ & & EEA, 2006 & $\begin{array}{l}\text { http://reports.eea.europa.eu/EMEPCO } \\
\text { RINAIR4/en/sources_of_PCB.pdf }\end{array}$ \\
\hline \multirow[t]{2}{*}{20103} & $\begin{array}{l}\text { commercial and institu- } \\
\text { tional plants (coal) }\end{array}$ & 1646.4 & $\mu \mathrm{g} / \mathrm{t}$ & $\begin{array}{l}\text { AEAT Environ- } \\
\text { ment, } 2001\end{array}$ & & \\
\hline & $\begin{array}{l}\text { small industrial wood- } \\
\text { burning furnace }\end{array}$ & 556 & $\mu \mathrm{g} / \mathrm{t}$ & $\begin{array}{l}\text { AEAT Environ- } \\
\text { ment, } 2001\end{array}$ & & \\
\hline 202 & Hard coal, residential & 1250 & $\mu \mathrm{g} / \mathrm{t}$ & & EEA, 2006 & $\begin{array}{l}\text { http://reports.eea.europa.eu/EMEPCO } \\
\text { RINAIR4/en/sources_of_PCB.pdf }\end{array}$ \\
\hline 202 & $\begin{array}{l}\text { Peat briquette, resi- } \\
\text { dential }\end{array}$ & 900 & $\mu \mathrm{g} / \mathrm{t}$ & & EEA, 2006 & $\begin{array}{l}\text { http://reports.eea.europa.eu/EMEPCO } \\
\text { RINAIR4/en/sources_of_PCB.pdf }\end{array}$ \\
\hline 202 & Firewood, residential & 600 & $\mu \mathrm{g} / \mathrm{t}$ & & EEA, 2006 & $\begin{array}{l}\text { http://reports.eea.europa.eu/EMEPCO } \\
\text { RINAIR4/en/sources_of_PCB.pdf }\end{array}$ \\
\hline 809 & $\begin{array}{l}\text { Hard coal, domestic } \\
\text { combustion }\end{array}$ & 600 & $\mu \mathrm{g} / \mathrm{t}$ & & EEA, 2006 & $\begin{array}{l}\text { http://reports.eea.europa.eu/EMEPCO } \\
\text { RINAIR4/en/sources_of_PCB.pdf }\end{array}$ \\
\hline 809 & $\begin{array}{l}\text { Peat briquette, do- } \\
\text { mestic combustion }\end{array}$ & 600 & $\mu \mathrm{g} / \mathrm{t}$ & & EEA, 2006 & $\begin{array}{l}\text { http://reports.eea.europa.eu/EMEPCO } \\
\text { RINAIR4/en/sources_of_PCB.pdf }\end{array}$ \\
\hline \multirow[t]{11}{*}{809} & $\begin{array}{l}\text { Firewood, domestic } \\
\text { combustion }\end{array}$ & 350 & $\mu \mathrm{g} / \mathrm{t}$ & & EEA, 2006 & $\begin{array}{l}\text { http://reports.eea.europa.eu/EMEPCO } \\
\text { RINAIR4/en/sources_of_PCB.pdf }\end{array}$ \\
\hline & $\begin{array}{l}\text { oak/wood, residential, } \\
\text { fireplace, woodstove }\end{array}$ & 8370 & $\mu \mathrm{g} / \mathrm{t}$ & Gullett, 2003 & & \\
\hline & $\begin{array}{l}\text { Small combustion } \\
\text { sources }\end{array}$ & 1400 & $\mu \mathrm{g} / \mathrm{t}$ & Bipro, 2006 & & $\begin{array}{l}\text { http://ec.europa.eu/environment/dio } \\
\text { xin/pdf/report.pdf }\end{array}$ \\
\hline & $\begin{array}{l}\text { Residential combus- } \\
\text { tion coal }\end{array}$ & 2000 & $\mu \mathrm{g} / \mathrm{t}$ & Bipro, 2006 & & $\begin{array}{l}\text { http://ec.europa.eu/environment/dio } \\
\text { xin/pdf/report.pdf }\end{array}$ \\
\hline & $\begin{array}{l}\text { Residential combus- } \\
\text { tion wood }\end{array}$ & 1000 & $\mu \mathrm{g} / \mathrm{t}$ & Bipro, 2006 & & $\begin{array}{l}\text { http://ec.europa.eu/environment/dio } \\
\text { xin/pdf/report.pdf }\end{array}$ \\
\hline & Mobile sources & & & & & \\
\hline & Road transport & 5000 & $\mu \mathrm{g} / \mathrm{t}$ & Bipro, 2006 & & $\begin{array}{l}\text { http://ec.europa.eu/environment/dio } \\
\text { xin/pdf/report.pdf }\end{array}$ \\
\hline & $\begin{array}{l}\text { Road transport, } \\
\text { unleaded motor } \\
\text { gasoline }\end{array}$ & 200 & $\mu \mathrm{g} / \mathrm{t}$ & & $\begin{array}{l}\text { Andrijewski, } \\
2004\end{array}$ & $\begin{array}{l}\text { http://www.mos.gov.pl/1strony_tematy } \\
\text { czne/ochrona_powietrza/ konwencje_ } \\
\text { ekologiczne/ konwencja_- } \\
\text { sztokholmska/NIP-Poland-eng.pdf }\end{array}$ \\
\hline & $\begin{array}{l}\text { Road transport, diesel, } \\
\text { cars and light duty } \\
\text { vehicles }\end{array}$ & 0.05 & $\mathrm{ng} / \mathrm{t}$ & & $\begin{array}{l}\text { Andrijewski, } \\
2004\end{array}$ & $\begin{array}{l}\text { http://www.mos.gov.pl/1strony_tematy } \\
\text { czne/ochrona_powietrza/ konwencje_ } \\
\text { ekologiczne/ konwencja_- } \\
\text { sztokholmska/NIP-Poland-eng.pdf }\end{array}$ \\
\hline & $\begin{array}{l}\text { Road transport, diesel } \\
\text { oil, heavy duty vehi- } \\
\text { cles }\end{array}$ & 5.39 & $\mathrm{ng} / \mathrm{t}$ & & $\begin{array}{l}\text { Andrijewski, } \\
2004\end{array}$ & $\begin{array}{l}\text { http://uww.mos.gov.pl/1strony_tematy } \\
\text { czne/ochrona_powietrza/ konwencje_ } \\
\text { ekologiczne/ konwencja_ } \\
\text { sztokholmska/NIP-Poland-eng.pdf }\end{array}$ \\
\hline & Marine transport & 600 & $\mu \mathrm{g} / \mathrm{t}$ & Bipro, 2006 & & $\begin{array}{l}\text { http://ec.europa.eu/environment/dio } \\
\text { xin/pdf/report.pdf }\end{array}$ \\
\hline 804 & Ships, residual oil & 0.07 & $\mathrm{ng} / \mathrm{t}$ & Cooper, 2005 & Cooper, 2004 & $\begin{array}{l}\text { http://www.ivl.se/rapporter/pdf/B162 } \\
\text { 0.pdf }\end{array}$ \\
\hline 804 & Ships, gas oil & 0.40 & $\mathrm{ng} / \mathrm{t}$ & Cooper, 2005 & Cooper, 2004 & $\begin{array}{l}\text { http://www.ivl.se/rapporter/pdf/B162 } \\
\text { 0.pdf }\end{array}$ \\
\hline 90201 & $\begin{array}{l}\text { Domestic or municipal } \\
\text { waste }\end{array}$ & 820 & $\mu \mathrm{g} / \mathrm{t}$ & & EEA, 2006 & $\begin{array}{l}\text { http://reports.eea.europa.eu/EMEP } \\
\text { CORINAIR4/en/sources_of_ } \\
\text { PCB.pdf }\end{array}$ \\
\hline
\end{tabular}

*SNAP: Source Nomenclature of Air Pollutants

The emissions factors marked in bold have been used for estimating the PCB emissions to air. Assuming that all combustion plants have adopted the best available APCDs, the emission factors provided in the Corinair guidebook (EEA, 2006) may be overestimated. For non-industrial, commercial and residential combustion, the emission factors provided by 
BiPro have been used as these are the latest reported values and are expected to be the most recently updated. It should be mentioned that lower EF values have been used in the Polish NIP (Andrijewski, 2004).

Table 1.4 Estimated HCB air emissions from fuel consuming activities

PRTR code HCB air emissions for potential stationary PRTR sources [g/yr]

A. Fuel Combustion Activities

Fuel type

1. Energy Industries

a. Public Electricity and Heat Production

Denmark

Finland

Norway

Sweden

2. Manufacturing Industries and Construction

Denmark

Finland

Norway

$\begin{array}{rrr}\text { Coal } & \text { Wood } & \text { MSW } \\ 94 & 82 & 3317\end{array}$

$\begin{array}{lrr}94 & 82 & 317\end{array}$

$\begin{array}{lrr}1 & 9 & 697\end{array}$

$\begin{array}{lll}7 & 460 & 3250\end{array}$

2, 3 Sweden

Coal Wood MSW

HCB air emissions [mg/yr], except for navigation which is given in [ng/yr]

3. Transport

a. Civil Aviation

Denmark

Finland

Norway

Sweden

b. Road Transportation

Denmark**

Finland

Norway

Sweden

d. Navigation

Aviation Gasoline

Jet Kerosene

NE

NE

NE

$19 \quad 184$

$828 \quad$ NO

$33-\mathrm{NO}$

$289 \quad$ NO

\begin{tabular}{|c|c|c|c|c|}
\hline & & & & \\
\hline & Finland & NE & $\mathrm{NE}$ & 225146 \\
\hline & Norway & NE & NE & 214620 \\
\hline & Sweden & NE & NE & 364849 \\
\hline & d. Navigation & $\begin{array}{r}\text { Residual Oil } \\
\text { (Residual Fuel Oil) }\end{array}$ & Gas/Diesel Oil & Gasoline \\
\hline & Denmark & 3 & 50 & NE \\
\hline 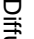 & Finland & 3 & 28 & NE \\
\hline$\frac{\bar{N}}{\bar{D}}$ & Norway & 11 & 141 & NE \\
\hline & Sweden & 5 & 28 & NE \\
\hline & 4. Other Sectors & & & \\
\hline & a. Commercial/Institutional & Coal & Wood & MSW \\
\hline & Denmark & NO & 528 & 17 \\
\hline & Finland & NO & 2252 & NO \\
\hline & Norway & NO & 93 & NO \\
\hline & Sweden & NO & 939 & NO \\
\hline & b. Residential & Coal & Wood & MSW \\
\hline & Denmark & 1.6 & 9376 & NO \\
\hline & Finland & 2.5 & 17067 & NO \\
\hline & Norway & 6.6 & 7820 & NO \\
\hline & Sweden & NO & 17565 & NO \\
\hline & $\begin{array}{l}\text { c. Agriculture/Forestryl } \\
\text { Fisheries }\end{array}$ & Coal & Wood & MSW \\
\hline & Denmark & 0.4 & 0.04 & \\
\hline & Finland & 0.03 & 2.1 & \\
\hline & Norway & $\mathrm{NO}$ & 0.02 & \\
\hline & Sweden & $\mathrm{NO}$ & 0.07 & \\
\hline
\end{tabular}

*'fuel independent' refers to the use of the EF from Joas et al., 2005, which is also used in the Finnish IIR, 2006. **Mobile transport divided into fuel types and given in units of $\mathrm{km} / \mathrm{yr}$ is only available for Denmark. Numbers for 2004 were used corresponding to 13 and 32 billion driven $\mathrm{km}$ on diesel and gasoline, respectively. 
Table 1.5 Estimated PCB air emissions from fuel consuming activities

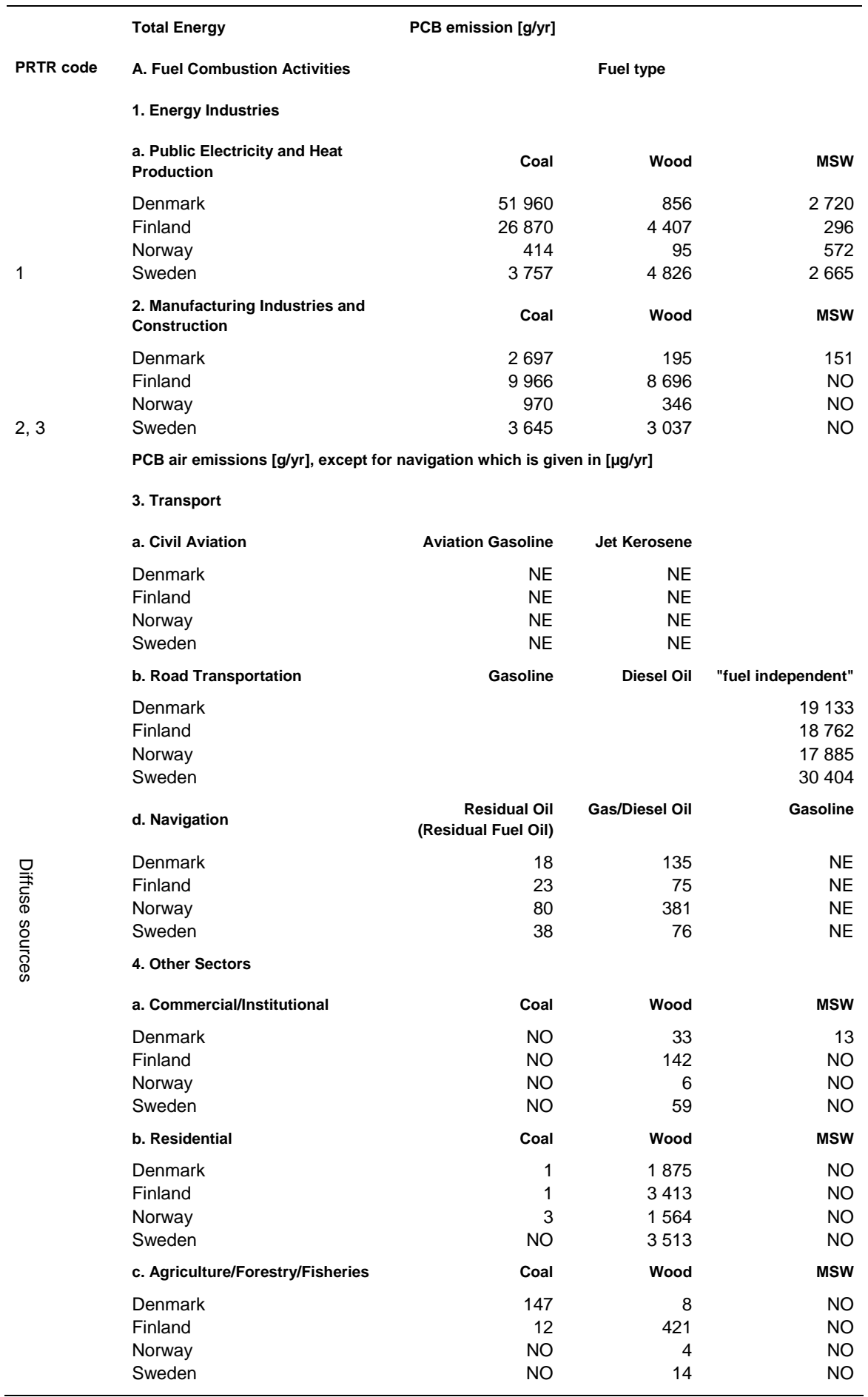


Table 1.6 Activity data for the petroleum industry - crude petroleum and refinery products.

\begin{tabular}{|c|c|c|c|c|c|c|c|}
\hline & Commodity & & 2001 & 2002 & 2003 & 2004 & 2005 \\
\hline \multirow[t]{11}{*}{ Denmark } & Petroleum: & & & & & & \\
\hline & Crude & $\begin{array}{l}\text { thousand } 42- \\
\text { gallon barrels }\end{array}$ & 123800 & 132900 & 133000 & 135000 & 131000 \\
\hline & Refinery products: & & & & & & \\
\hline & Liquefied petroleum gas & do. & 1224 & 1195 & 1232 & 1240 & 1250 \\
\hline & Gasoline & do. & 16496 & 15205 & 15264 & 15300 & 15400 \\
\hline & Naphtha & do. & 13000 & -- & -- & -- & -- \\
\hline & Jet fuel & do. & 3981 & 3878 & 4479 & 4500 & 4800 \\
\hline & Distillate fuel oil & do. & 23606 & 23886 & 25300 & 25500 & 26000 \\
\hline & Refinery gas & do. & 2221 & 2141 & 2331 & 2300 & 2200 \\
\hline & Residual fuel oil & do. & 11488 & 11540 & 11136 & 11000 & 11300 \\
\hline & Total & do. & 72000 & 57845 & 59700 & 59800 & 61000 \\
\hline Finland & Petroleum refinery products & $\begin{array}{l}\text { thousand } 42- \\
\text { gallon barrels }\end{array}$ & 42318 & 54801 & 54956 & 61037 & 78796 \\
\hline \multirow[t]{12}{*}{ Norway } & Petroleum: & & & & & & \\
\hline & Crude $^{5}$ & $\begin{array}{l}\text { thousand } 42- \\
\text { gallon barrels }\end{array}$ & 1138400 & 1092800 & 1041400 & 1024400 & 964290 \\
\hline & Natural gas liquids ${ }^{\mathrm{e}}$ & do. & 41000 & 41000 & 42000 & 52695 & 60879 \\
\hline & Refinery products: $^{\mathrm{e}}$ & & & & & & \\
\hline & Naphtha & do. & 27000 & 27000 & 27000 & 8741 & 10017 \\
\hline & Gasoline & do. & 26000 & 26000 & 27000 & 23913 & 28078 \\
\hline & Kerosene & do. & 9000 & 9000 & 9000 & 4774 & 5771 \\
\hline & Distillate fuel oil & do. & 46000 & 46000 & 47000 & 45765 & 50121 \\
\hline & Residual fuel oil & do. & 12000 & 12000 & 12000 & 13823 & 11806 \\
\hline & Other products & do. & 4500 & 5000 & 5000 & 3351 & 4194 \\
\hline & Refinery fuel and losses & do. & 4000 & 5000 & 5000 & 2757 & 2977 \\
\hline & Total & do. & 129000 & 130000 & 132000 & 103124 & 112964 \\
\hline \multirow[t]{11}{*}{ Sweden } & Petroleum, refinery products: ${ }^{\mathrm{e}}$ & & & & & & \\
\hline & Liquefied petroleum gas & $\begin{array}{l}\text { thousand } 42- \\
\text { gallon barrels }\end{array}$ & 3000 & 3000 & 3000 & 3000 & 4000 \\
\hline & Naphtha & do. & 500 & 500 & 500 & 500 & 500 \\
\hline & Gasoline, motor & do. & 40000 & 40000 & 41000 & 41000 & 41000 \\
\hline & Jet fuel & do. & 1500 & 1500 & 1600 & 1600 & 1600 \\
\hline & Kerosene & do. & 50 & 50 & 50 & 50 & 50 \\
\hline & Distillate fuel oil & do. & 57000 & 58000 & 58000 & 59000 & 60000 \\
\hline & Residual fuel oil & do. & 39000 & 40000 & 40000 & 41000 & 41000 \\
\hline & Other & do. & 7800 & 7800 & 8000 & 8000 & 8000 \\
\hline & Refinery fuel and losses & do. & 5000 & 5000 & 5000 & 5000 & 5000 \\
\hline & Total & do. & 154000 & 156000 & 157000 & 159000 & 161000 \\
\hline
\end{tabular}

Reference: US Geological survey, http://minerals.usgs.gov/minerals/pubs/country/europe.html

A conversion factor from gallon barrels to tonnes of $0.1364^{9}$ has been used for deriving the activity data given in the Table 3 of the main report.

${ }^{9}$ Source:http://www.globallngonline.com/index.asp?q=cf\&ID=1024 


\section{Annex 2. Potential sources within the metal and mineral industry sectors}

The figures provided in the annex provide data and information that was available at the time the work was carried out on the report. To the best efforts of the authors, data covers all information regarding relevant sources within the metal and mineral industries. Still, processes outside the knowledge of the authors may very well exist. Therefore the annex represents a screening level review of knowledge on potential sources of UPOPs. 


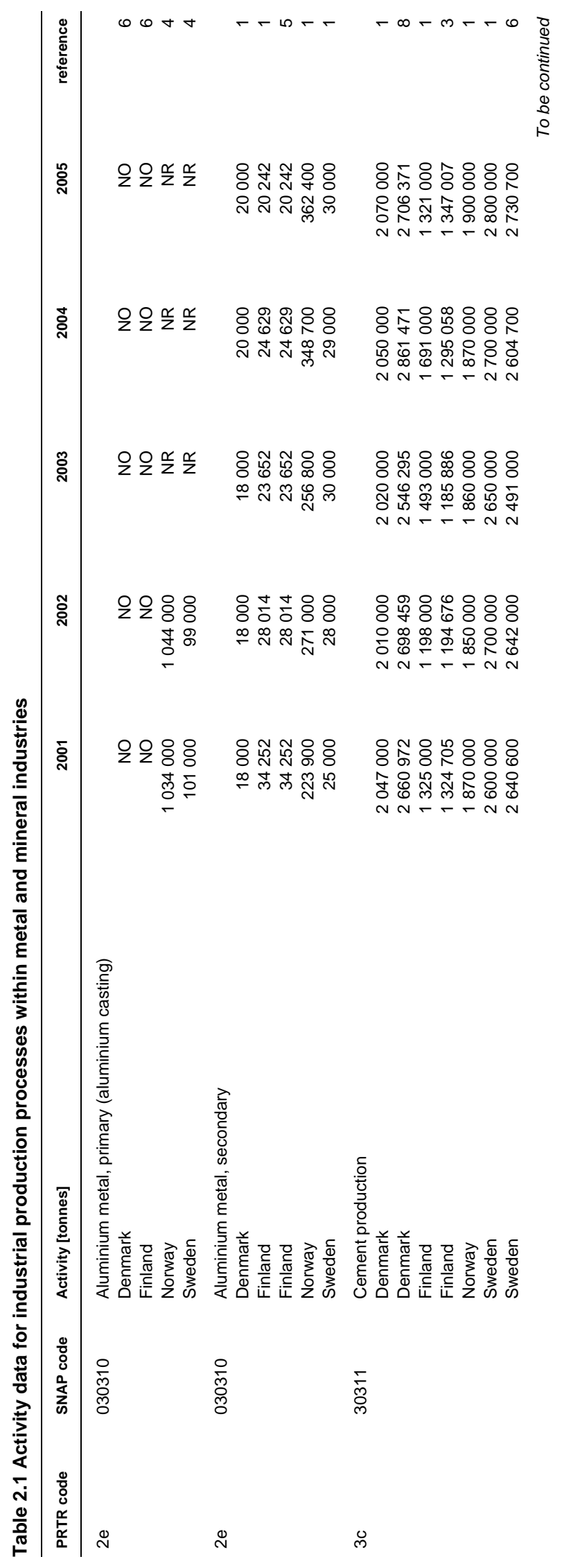



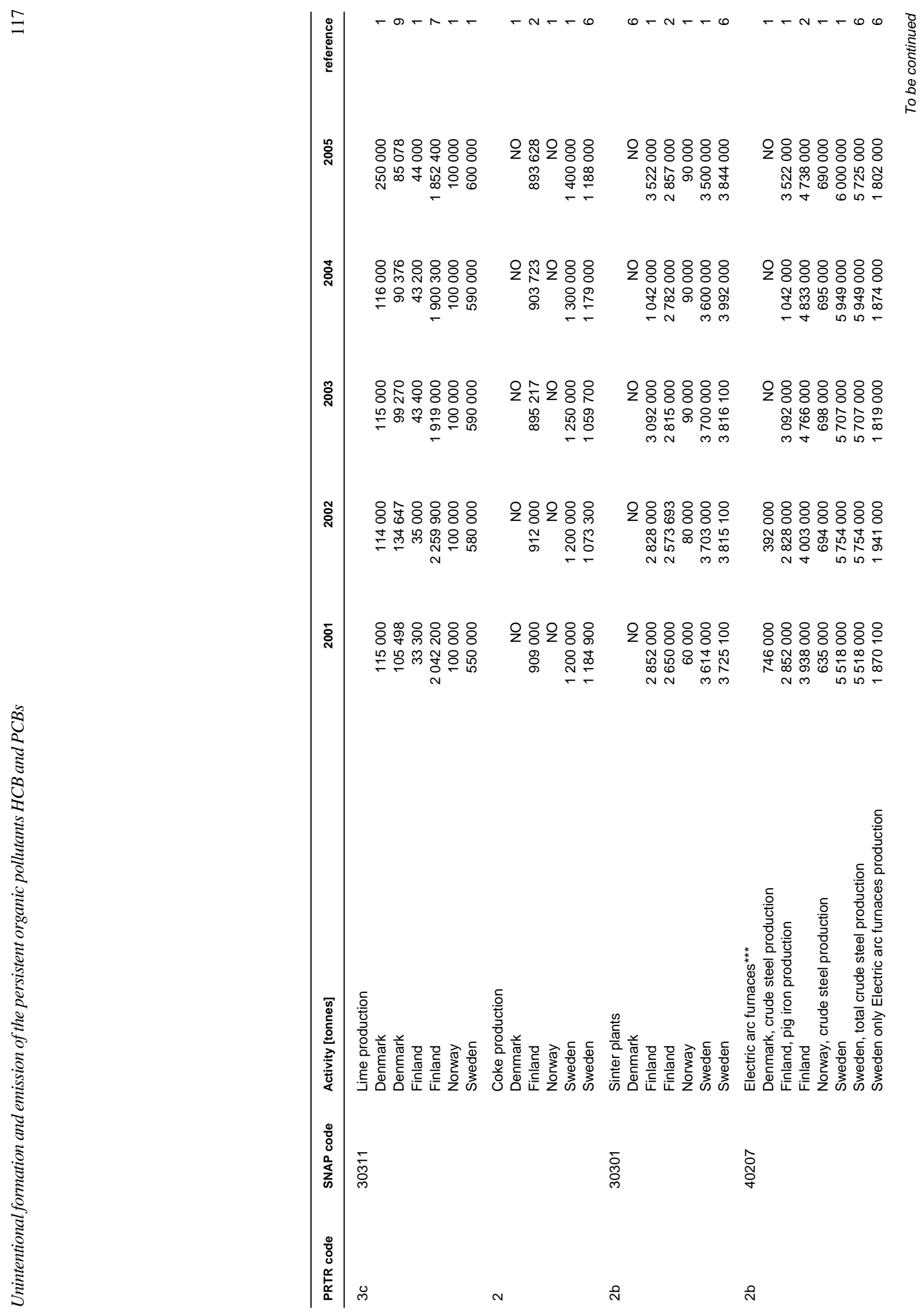


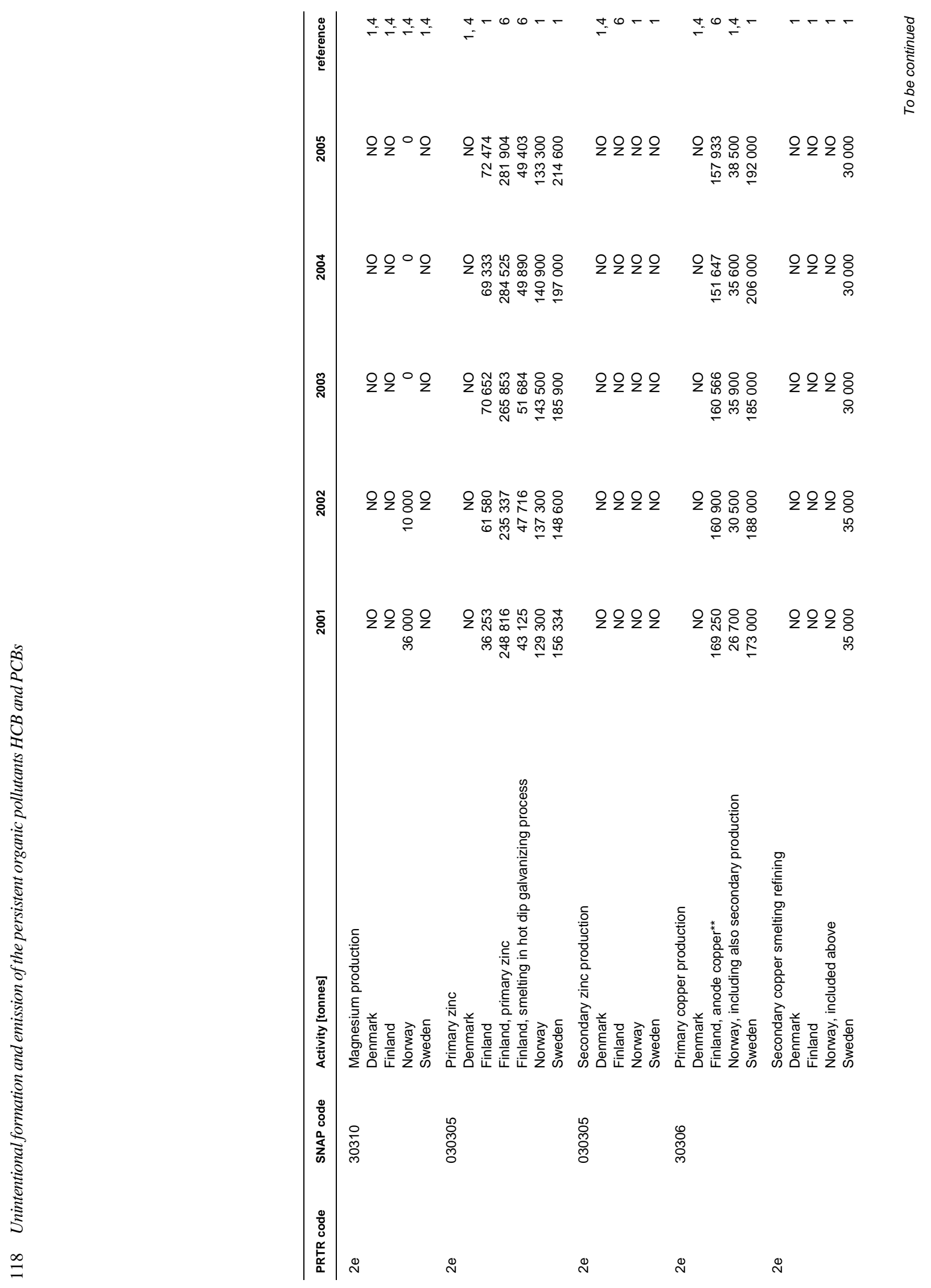




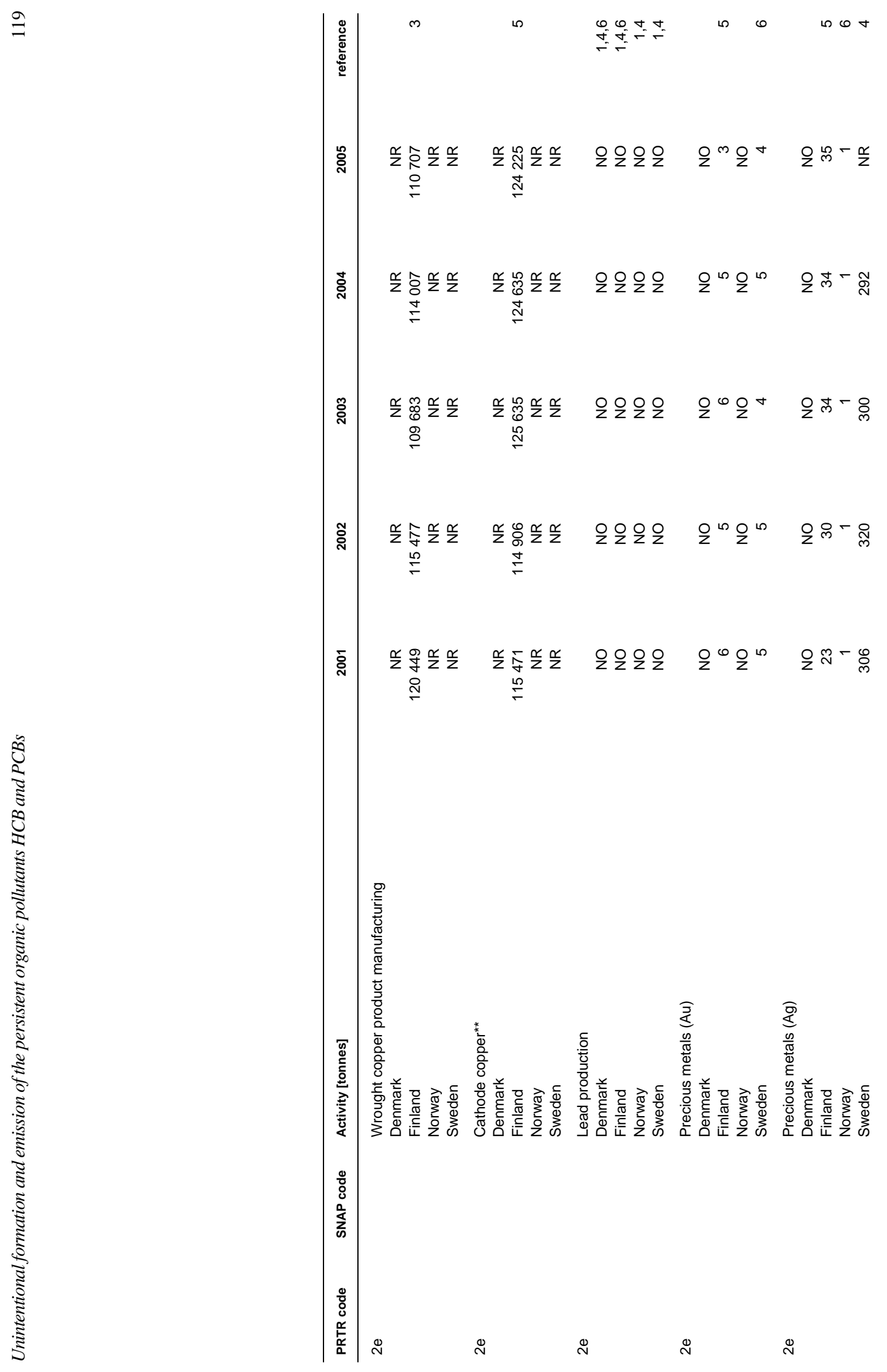




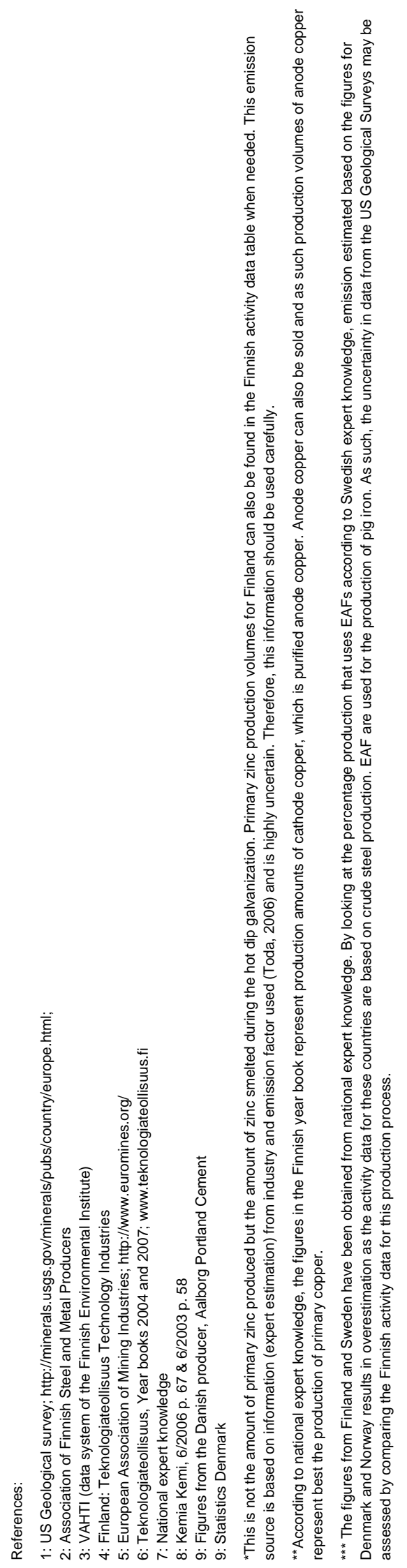


For some of the production processes, figures for the same activity from different literature references and knowledge sources are provided. In most cases the figures agree, as observed from Table 2.1, which indicates that the data are at a suitable quality level for the purpose of this screening level assessment of potential sources to UPOP emissions.

In the case of primary zinc production, the figures from Finland are specific to smelting in hot dip galvanizing process. Such specialized information has not been available for this present work. Still, the Finnish data for primary zinc production by smelting in hot dip galvanizing process are at the same level as the data extracted from the US Geological Survey database and assumed to represent primary zinc production as a source of unintentional HCB emission at an acceptable level of accuracy for the purpose of this screening level assessment of sources of UPOP emissions. 
Table 2.2 Air emission factors (EF) for HCB from industrial production processes within metal and mineral industries.

\begin{tabular}{|c|c|c|c|c|c|}
\hline $\begin{array}{l}\text { PRTR } \\
\text { code }\end{array}$ & $\begin{array}{l}\text { SNAP } \\
\text { code }\end{array}$ & Activity [tonnes] & $E F[\mu g / t]$ & Reference $^{*}$ & www \\
\hline $2 e$ & & $\begin{array}{l}\text { Aluminium metal, primary } \\
\text { (aluminium casting) }\end{array}$ & 295 & $\begin{array}{l}\text { Saarinen et al., } \\
2007\end{array}$ & $\begin{array}{l}\text { http://www.ymparisto.fi/download.asp?c } \\
\text { ontentid=67644\&lan=sv }\end{array}$ \\
\hline \multirow[t]{5}{*}{$2 \mathrm{e}$} & 030310 & Aluminium metal, secondary & 5000000 & EEA,2006 & $\begin{array}{l}\text { http://reports.eea.europa.eu/EMEPCO } \\
\text { RINAIR4/en/sources_of_PCB.pdf }\end{array}$ \\
\hline & & & 2200000 & Bailey,2001 & \\
\hline & & & 20000 & Bipro,2006 & $\begin{array}{l}\text { http://ec.europa.eu/environment/dioxin/ } \\
\text { pdf/report.pdf }\end{array}$ \\
\hline & & & 660 & $\begin{array}{l}\text { Saarinen et al., } \\
2007\end{array}$ & $\begin{array}{l}\text { http://www.ymparisto.fi/download.asp?c } \\
\text { ontentid=67644\&lan=sv }\end{array}$ \\
\hline & & & 1365 & $\begin{array}{l}\text { Finland, Expert } \\
\text { knowæledge }\end{array}$ & \\
\hline \multirow[t]{4}{*}{ 3c } & 30311 & Cement production & 11 & EEA,2006 & $\begin{array}{l}\text { http://reports.eea.europa.eu/EMEPCO } \\
\text { RINAIR4/en/sources_of_PCB.pdf }\end{array}$ \\
\hline & & & $17-1700$ & Bailey,2001 & \\
\hline & & & 21 & $\begin{array}{l}\text { Andrijewski, } \\
2004\end{array}$ & $\begin{array}{l}\text { http://www.mos.gov.pl/1strony_tematyc } \\
\text { zne/ochrona_powietrza/ konwencje_- } \\
\text { ekologiczne/konwencja_sztokholmska/ } \\
\text { NIP-Poland-eng.pdf }\end{array}$ \\
\hline & & & 10 & Bipro,2006 & $\begin{array}{l}\text { http://ec.europa.eu/environment/dioxin/ } \\
\text { pdf/report.pdf }\end{array}$ \\
\hline $3 c$ & 30311 & Lime production & 8 & Bipro,2006 & $\begin{array}{l}\text { http://ec.europa.eu/environment/dioxin/ } \\
\text { pdf/report.pdf }\end{array}$ \\
\hline \multirow[t]{4}{*}{2} & 30301 & Sinter plants & 32 & EEA,2006 & $\begin{array}{l}\text { http://reports.eea.europa.eu/EMEPCO } \\
\text { RINAIR4/en/sources_of_PCB.pdf }\end{array}$ \\
\hline & & & $150-15000$ & Bailey,2001 & \\
\hline & & & 2300 & Bipro,2006 & $\begin{array}{l}\text { http://ec.europa.eu/environment/dioxin/ } \\
\text { pdf/report.pdf }\end{array}$ \\
\hline & & & 140 & $\begin{array}{l}\text { Andrijewski, } \\
2004\end{array}$ & $\begin{array}{l}\text { http://www.mos.gov.pl/1strony_tematyc } \\
\text { zne/ochrona_powietrza/konwencje_- } \\
\text { ekologiczne/konwencja_sztokholmska/ } \\
\text { NIP-Poland-eng.pdf }\end{array}$ \\
\hline $2 d$ & 40207 & Electric arc furnaces & 2000 & Bipro,2006 & $\begin{array}{l}\text { http://ec.europa.eu/environment/dioxin/ } \\
\text { pdf/report.pdf }\end{array}$ \\
\hline \multirow[t]{3}{*}{$2 b$} & 30310 & Magnesium production & $90000-3000000$ & EEA,2006 & $\begin{array}{l}\text { http://reports.eea.europa.eu/EMEPCO } \\
\text { RINAIR4/en/sources_of_PCB.pdf }\end{array}$ \\
\hline & & & 300000 & Bipro,2006 & $\begin{array}{l}\text { http://ec.europa.eu/environment/dioxin/ } \\
\text { pdf/report.pdf }\end{array}$ \\
\hline & & & 500000 & Bipro, 2006 & \\
\hline $2 e$ & 030305 & $\begin{array}{l}\text { Primary zinc smelting in hot } \\
\text { dip galvanizing process }\end{array}$ & 1456 & Toda, 2005 & $\begin{array}{l}\text { http://www.ymparisto.fi/download.asp?c } \\
\text { ontentid=67644\&lan=sv }\end{array}$ \\
\hline $2 \mathrm{e}$ & 030305 & Secondary zinc production & 10000 & Bipro,2006 & $\begin{array}{l}\text { http://ec.europa.eu/environment/dioxin/ } \\
\text { pdf/report.pdf }\end{array}$ \\
\hline \multirow[t]{3}{*}{$2 \mathrm{e}$} & 30306 & $\begin{array}{l}\text { Secondary copper smelting } \\
\text { refining }\end{array}$ & $3900-390000$ & Bailey,2001 & \\
\hline & & & 39000 & Pacyna, 2003 & \\
\hline & & & 20000 & Bipro,2006 & $\begin{array}{l}\text { http://ec.europa.eu/environment/dioxin/ } \\
\text { pdf/report.pdf }\end{array}$ \\
\hline $2 e$ & & $\begin{array}{l}\text { Wrought copper product } \\
\text { manufacturing }\end{array}$ & 17524 & $\begin{array}{l}\text { Japan Invento- } \\
\text { ry, } 2005\end{array}$ & \\
\hline $2 e$ & & Lead production & 300 & Bipro,2006 & $\begin{array}{l}\text { http://ec.europa.eu/environment/dioxin/ } \\
\text { pdf/report.pdf }\end{array}$ \\
\hline $2 \mathrm{e}$ & & Precious metals & 204000 & Bipro,2006 & $\begin{array}{l}\text { http://ec.europa.eu/environment/dioxin/ } \\
\text { pdf/report.pdf }\end{array}$ \\
\hline 2 & & Iron foundries & 40 & Bipro,2006 & $\begin{array}{l}\text { http://ec.europa.eu/environment/dioxin/ } \\
\text { pdf/report.pdf }\end{array}$ \\
\hline 6 & & Pulp and Paper & 9 & Bipro,2006 & $\begin{array}{l}\text { http://ec.europa.eu/environment/dioxin/ } \\
\text { pdf/report.pdf }\end{array}$ \\
\hline
\end{tabular}

*Detailed information on the references may be found in the List of references 
Emission factors used for deriving estimated HCB emissions to air are marked in bold. EF values from the most up-to-date references have been selected, preferable to those from European studies.

Non-ferrous, e.g. aluminium casting, may occur in Norway and Sweden as the figures provided by the European Association of Mining Industries covers only 2000-2002 (see Table 2.1).

Table 2.3 Air emission factors (EF) for PCB from industrial production processes within metal and mineral industries.

\begin{tabular}{|c|c|c|c|c|c|}
\hline $\begin{array}{l}\text { PRTR } \\
\text { code }\end{array}$ & $\begin{array}{l}\text { SNAP } \\
\text { code }\end{array}$ & Activity [tonnes] & $E F[\mu g / t]$ & Reference & www \\
\hline $1 a$ & & $\begin{array}{l}\text { Petrol refinery } \\
\text { (residual oil) }\end{array}$ & 1000 & Bipro, 2006 & $\begin{array}{l}\text { http://ec.europa.eu/environment/dioxi } \\
\text { n/pdf/report.pdf }\end{array}$ \\
\hline $2 e$ & 030310 & $\begin{array}{l}\text { Aluminium metal, } \\
\text { secondary }\end{array}$ & 3400 & Bipro,2006 & $\begin{array}{l}\text { http://ec.europa.eu/environment/dioxi } \\
\text { n/pdf/report.pdf }\end{array}$ \\
\hline \multirow[t]{2}{*}{$3 c$} & 30311 & $\begin{array}{l}\text { Cement produc- } \\
\text { tion }\end{array}$ & 2000 & Bipro,2006 & $\begin{array}{l}\text { http://ec.europa.eu/environment/dioxi } \\
\text { n/pdf/report.pdf }\end{array}$ \\
\hline & & & 7 & Andrijewski, 2004 & $\begin{array}{l}\text { http://www.mos.gov.pl/1strony_temat } \\
\text { yczne/ochrona_powietrza/konwencje } \\
\text { ekologiczne/konwencja_sztokholms } \\
\text { ka/ NIPPoland-eng.pdf }\end{array}$ \\
\hline $3 c$ & 30311 & Lime production & 150 & Bipro,2006 & $\begin{array}{l}\text { http://ec.europa.eu/environment/dioxi } \\
\text { n/pdf/report.pdf }\end{array}$ \\
\hline $2 \mathrm{e}$ & & Coke production & 3600 & Bipro,2006 & $\begin{array}{l}\text { http://ec.europa.eu/environment/dioxi } \\
\text { n/pdf/report.pdf }\end{array}$ \\
\hline \multirow[t]{4}{*}{2} & 30301 & Sinter plants & 200 & EEA,2006 & $\begin{array}{l}\text { http://reports.eea.europa.eu/EMEPC } \\
\text { ORINAIR4/en/sources_of_PCB.pdf }\end{array}$ \\
\hline & & & 500 & Bipro,2006 & $\begin{array}{l}\text { http://ec.europa.eu/environment/dioxi } \\
\text { n/pdf/report.pdf }\end{array}$ \\
\hline & & & $1000-13000$ & IPPC, BREF IS, 2001 & \\
\hline & & & 65 & Andrijewski, 2004 & $\begin{array}{l}\text { http://www.mos.gov.pl/1strony_temat } \\
\text { yczne/ochrona_powietrza/konwencje } \\
\text { ekologiczne/konwencja_sztokholms } \\
\text { ka// NIP-Poland-eng.pdf }\end{array}$ \\
\hline \multirow[t]{4}{*}{$2 d$} & 40207 & $\begin{array}{l}\text { Electric arc } \\
\text { furnaces }\end{array}$ & 3600 & EEA,2006 & $\begin{array}{l}\text { http://reports.eea.europa.eu/EMEPC } \\
\text { ORINAIR4/en/sources_of_PCB.pdf }\end{array}$ \\
\hline & & & $1500-4500$ & IPPC,BREF IS,2001 & \\
\hline & & & 5000 & Bipro,2006 & $\begin{array}{l}\text { http://ec.europa.eu/environment/dioxi } \\
\text { n/pdf/report.pdf }\end{array}$ \\
\hline & & & 1500 & IPPC, BREF IS, 2001 & \\
\hline 2 & 030305 & $\begin{array}{l}\text { Secondary zinc } \\
\text { production }\end{array}$ & 1000 & Bipro,2006 & $\begin{array}{l}\text { http://ec.europa.eu/environment/dioxi } \\
\text { n/pdf/report.pdf }\end{array}$ \\
\hline 2 & 30306 & $\begin{array}{l}\text { Primary copper } \\
\text { production }\end{array}$ & 100 & Bipro,2006 & $\begin{array}{l}\text { http://ec.europa.eu/environment/dioxi } \\
\text { n/pdf/report.pdf }\end{array}$ \\
\hline 2 & & $\begin{array}{l}\text { Secondary } \\
\text { copper smelting } \\
\text { refining }\end{array}$ & 2600 & Bipro,2006 & $\begin{array}{l}\text { http://ec.europa.eu/environment/dioxi } \\
\text { n/pdf/report.pdf }\end{array}$ \\
\hline 2 & & Lead production & 7250 & Bipro,2006 & $\begin{array}{l}\text { http://ec.europa.eu/environment/dioxi } \\
\text { n/pdf/report.pdf }\end{array}$ \\
\hline 2 & & Precious metals & 160000 & Bipro,2006 & $\begin{array}{l}\text { http://ec.europa.eu/environment/dioxi } \\
\text { n/pdf/report.pdf }\end{array}$ \\
\hline \multirow{2}{*}{\multicolumn{2}{|c|}{2}} & Iron foundries & 500 & Bipro,2006 & $\begin{array}{l}\text { http://ec.europa.eu/environment/dioxi } \\
\text { n/pdf/report.pdf }\end{array}$ \\
\hline & & Shredder & 5200 & Bipro,2006 & $\begin{array}{l}\text { http://ec.europa.eu/environment/dioxi } \\
\text { n/pdf/report.pdf }\end{array}$ \\
\hline 6 & & Pulp and Paper & 700 & Bipro,2006 & $\begin{array}{l}\text { http://ec.europa.eu/environment/dioxi } \\
\text { n/pdf/report.pdf }\end{array}$ \\
\hline
\end{tabular}

*Detailed information on the references may be found in the List of references.

Emission factors used for deriving estimated PCB emissions to air are marked in bold. EF values from the most up-to-date references have been selected, preferable to those from European studies. 
The Nordic countries have no iron foundries or lead production. Still, the emission factors have been included for the purpose of an overview of potential sources to emissions where such activities are present.

Table 2.4 Estimated HCB air emissions from the metal and mineral industries [ $\mathrm{g} / \mathrm{gr}]$

\begin{tabular}{|c|c|c|c|c|c|c|c|}
\hline $\begin{array}{l}\text { PRTR } \\
\text { code }\end{array}$ & $\begin{array}{l}\text { SNAP } \\
\text { code }\end{array}$ & Production process & 2001 & 2002 & 2003 & 2004 & 2005 \\
\hline \multirow[t]{5}{*}{$2 e$} & 030310 & Aluminium metal, primary (aluminium casting) & & & & & \\
\hline & & Denmark & NO & NO & NO & NO & NO \\
\hline & & Finland & NO & NO & NO & NO & NO \\
\hline & & Norway & 305 & 308 & NR & NR & NR \\
\hline & & Sweden & 30 & 29 & NR & NR & NR \\
\hline \multirow[t]{5}{*}{$2 e$} & 030310 & Aluminium metal, secondary & & & & & \\
\hline & & Denmark & 12 & 12 & 12 & 13 & 13 \\
\hline & & Finland & 23 & 18 & 16 & 16 & 13 \\
\hline & & Norway & 148 & 179 & 169 & 230 & 239 \\
\hline & & Sweden & 17 & 18 & 20 & 19 & 20 \\
\hline \multirow[t]{5}{*}{$2 e$} & & Secondary copper smelting refining & & & & & \\
\hline & & Denmark & NO & NO & NO & NO & NO \\
\hline & & Finland & NO & NO & NO & NO & NO \\
\hline & & Norway (rep. und. Prim. as sum of secondary and prim.) & NR & NR & NR & NR & NR \\
\hline & & Sweden & 700 & 700 & 600 & 600 & 600 \\
\hline \multirow[t]{5}{*}{$2 e$} & & Wrought copper product manufacturing & & & & & \\
\hline & & Denmark & NR & NR & NR & NR & NR \\
\hline & & Finland & 36 & 35 & 33 & 34 & 33 \\
\hline & & Norway & NR & NR & NR & NR & NR \\
\hline & & Sweden & NR & NR & NR & NR & NR \\
\hline \multirow[t]{5}{*}{$2 b$} & 30310 & Magnesium production & & & & & \\
\hline & & Denmark & NO & NO & NO & NO & NO \\
\hline & & Finland & NO & NO & NO & NO & NO \\
\hline & & Norway & 10800 & 3000 & 0 & 0 & 0 \\
\hline & & Sweden & NO & NO & NO & NO & NO \\
\hline \multirow[t]{5}{*}{$2 \mathrm{e}$} & 030305 & Primary zinc smelting in hot dip galvanizing process & & & & & \\
\hline & & Denmark & NO & NO & NO & NO & NO \\
\hline & & Finland & 63 & 69 & 75 & 73 & 72 \\
\hline & & Norway & 188 & 200 & 209 & 205 & 194 \\
\hline & & Sweden & 228 & 216 & 271 & 287 & 313 \\
\hline \multirow[t]{5}{*}{$2 e$} & & Precious metals & & & & & \\
\hline & & Denmark & NO & NO & NO & NO & NO \\
\hline & & Finland & 6 & 7 & 8 & 8 & 8 \\
\hline & & Norway & 0.3 & 0.2 & 0.2 & 0.2 & 0.2 \\
\hline & & Sweden & 63 & 66 & 62 & 61 & 1 \\
\hline \multirow[t]{5}{*}{$2 b$} & 30301 & Sinter plants & & & & & \\
\hline & & Denmark & NO & NO & NO & NO & NO \\
\hline & & Finland & 85 & 82 & 90 & 89 & 91 \\
\hline & & Norway & 2 & 3 & 3 & 3 & 3 \\
\hline & & Sweden & 119 & 122 & 122 & 128 & 123 \\
\hline \multirow[t]{5}{*}{$2 b$} & 40207 & Electric arc furnaces & & & & & \\
\hline & & Denmark & 1492 & 784 & NO & NO & NO \\
\hline & & Finland & 7876 & 8008 & 9532 & 9666 & 9476 \\
\hline & & Norway & 1270 & 1388 & 1396 & 1390 & 1380 \\
\hline & & Sweden & 3740 & 3882 & 3638 & 3748 & 3604 \\
\hline \multirow[t]{5}{*}{$3 c$} & 30311 & Cement production & & & & & \\
\hline & & Denmark & 27 & 27 & 25 & 29 & 27 \\
\hline & & Finland & 13 & 12 & 12 & 13 & 13 \\
\hline & & Norway & 13 & 12 & 12 & 13 & 13 \\
\hline & & Sweden & 26 & 26 & 25 & 26 & 27 \\
\hline \multirow[t]{5}{*}{$3 c$} & 30311 & Lime production & & & & & \\
\hline & & Denmark & 0.84 & 1.08 & 0.79 & 0.72 & 0.68 \\
\hline & & Finland & 16.34 & 18.08 & 15.35 & 15.20 & 14.82 \\
\hline & & Norway & 0.80 & 0.80 & 0.80 & 0.80 & 0.80 \\
\hline & & Sweden & 4.40 & 4.64 & 4.72 & 4.72 & 4.80 \\
\hline
\end{tabular}


Table 2.5 Estimated PCB air emissions from the metal and mineral industries [ $\mathrm{g} / \mathrm{gr}]$

\begin{tabular}{|c|c|c|c|c|c|c|c|}
\hline $\begin{array}{l}\text { PRTR } \\
\text { activity }\end{array}$ & SNAP & Production processes & 2001 & 2002 & 2003 & 2004 & 2005 \\
\hline \multirow[t]{5}{*}{$2 \mathrm{e}$} & 030310 & Aluminium metal, secondary & & & & & \\
\hline & & Denmark & 61 & 61 & 61 & 68 & 68 \\
\hline & & Finland & 116 & 95 & 80 & 84 & 69 \\
\hline & & Norway & 761 & 921 & 873 & 1186 & 1232 \\
\hline & & Sweden & 85 & 95 & 102 & 99 & 102 \\
\hline \multirow[t]{5}{*}{$2 \mathrm{e}$} & 30306 & Primary copper production & & & & & \\
\hline & & Denmark & NO & NO & NO & NO & NO \\
\hline & & Finland, anode copper ${ }^{\star \star}$ & 17 & 16 & 16 & 15 & 16 \\
\hline & & Norway, including also secondary production & 3 & 3 & 4 & 4 & 4 \\
\hline & & Sweden & 17 & 19 & 19 & 21 & 19 \\
\hline \multirow[t]{5}{*}{$2 \mathrm{e}$} & & Secondary copper smelting refining & & & & & \\
\hline & & Denmark & NO & NO & NO & NO & NO \\
\hline & & Finland & NO & NO & NO & NO & NO \\
\hline & & Norway & NO & NO & NO & NO & NO \\
\hline & & Sweden & 91 & 91 & 78 & 78 & 78 \\
\hline \multirow[t]{5}{*}{$2 \mathrm{e}$} & & Precious metals & & & & & \\
\hline & & Denmark & NO & NO & NO & NO & NO \\
\hline & & Finland & 5 & 10 & 11 & 11 & 11 \\
\hline & & Norway & 0.2 & 0.2 & 0.2 & 0.2 & 0 \\
\hline & & Sweden & 50 & 52 & 49 & 48 & 1 \\
\hline \multirow[t]{5}{*}{$2 b$} & 30301 & Sinter plants & & & & & \\
\hline & & Denmark & NO & NO & NO & NO & NO \\
\hline & & Finland & 530 & 515 & 563 & 556 & 571 \\
\hline & & Norway & 12 & 16 & 18 & 18 & 18 \\
\hline & & Sweden & 745 & 763 & 763 & 798 & 769 \\
\hline \multirow[t]{5}{*}{$2 b$} & 40207 & Electric arc furnaces & & & & & \\
\hline & & Denmark & 1119 & 588 & NO & NO & NO \\
\hline & & Finland & 5907 & 6006 & 7149 & 7250 & 7107 \\
\hline & & Norway & 953 & 1041 & 1047 & 1043 & 1035 \\
\hline & & Sweden & 2805 & 2912 & 2729 & 2811 & 2703 \\
\hline \multirow[t]{5}{*}{2} & & Coke production & & & & & \\
\hline & & Denmark & NO & NO & NO & NO & NO \\
\hline & & Finland & 3272 & 3283 & 3223 & 3253 & 3217 \\
\hline & & Norway & NO & NO & NO & NO & NO \\
\hline & & Sweden & 4266 & 3864 & 3815 & 4244 & 4277 \\
\hline \multirow[t]{5}{*}{$3 c$} & 30311 & Cement production & & & & & \\
\hline & & Denmark & 5322 & 5397 & 5093 & 5723 & 5413 \\
\hline & & Finland & 2649 & 2389 & 2372 & 2590 & 2694 \\
\hline & & Norway & 3740 & 3700 & 3720 & 3740 & 3800 \\
\hline & & Sweden & 5281 & 5284 & 4982 & 5209 & 5461 \\
\hline \multirow[t]{5}{*}{ 3c } & 30311 & Lime production & & & & & \\
\hline & & Denmark & 16 & 20 & 15 & 14 & 13 \\
\hline & & Finland & 306 & 339 & 288 & 285 & 278 \\
\hline & & Norway & 15 & 15 & 15 & 15 & 15 \\
\hline & & Sweden & 83 & 87 & 89 & 89 & 90 \\
\hline
\end{tabular}





\section{Annex 3. Potential sources within the Chemical industry}

\begin{tabular}{|c|c|c|c|c|c|c|c|c|c|}
\hline $\begin{array}{l}\text { PRTR } \\
\text { code }\end{array}$ & SNAP & Tonnes & 1999 & 2000 & 2001 & 2002 & 2003 & 2004 & 2005 \\
\hline \multirow[t]{30}{*}{$4 a$} & & & & \multicolumn{6}{|c|}{ Chlorinated solvent production } \\
\hline & & Denmark* & 63 & 9 & 0 & 4,068 & 804 & NR & NR \\
\hline & & Finland & 0 & 0 & 0 & 0 & 0 & 0 & 0 \\
\hline & & Norway & NR & NR & NR & NR & NR & NR & NR \\
\hline & & Sweden & NR & NR & NR & NR & NR & NR & NR \\
\hline & 40413 & tetrachloromethane & & & & & & & \\
\hline & & Denmark & 0 & 0 & 0 & 0 & 0 & 0 & 0 \\
\hline & & Finland & 0 & 0 & 0 & 0 & 0 & 0 & 0 \\
\hline & & Norway & NR & NR & NR & NR & NR & NR & NR \\
\hline & & Sweden & NR & NR & NR & NR & NR & NR & NR \\
\hline & 40413 & trichloroethylene & & & & & & & \\
\hline & & Denmark & 0 & 0 & 0 & 0 & 0 & & \\
\hline & & Finland & 0 & 0 & 0 & 0 & 0 & 0 & 0 \\
\hline & & Norway & NR & NR & NR & NR & NR & NR & NR \\
\hline & & Sweden & NR & NR & NR & NR & NR & NR & NR \\
\hline & 40413 & tetrachlorosthylene & & & & & & & \\
\hline & & Denmark & 61 & 9 & 0 & 0 & 0 & 0 & 0 \\
\hline & & Finland & 0 & 0 & 0 & 0 & 0 & 0 & 0 \\
\hline & & Norway & NR & NR & NR & NR & NR & & NR \\
\hline & & Sweden & $N R$ & $N R$ & NR & NR & NR & & NR \\
\hline & & 1,1,1-trichloroethane & & & & & & & \\
\hline & & Denmark & 0 & 0 & 0 & 0 & 0 & 0 & 0 \\
\hline & & Finland & 0 & 0 & 0 & 0 & 0 & 0 & 0 \\
\hline & & Norway & NR & NR & NR & NR & NR & NR & NR \\
\hline & & Sweden & NR & NR & NR & NR & NR & NR & NR \\
\hline & 40413 & perchloroethane & & & & & & & \\
\hline & & Denmark & 0 & 0 & 0 & 0 & 0 & 0 & 0 \\
\hline & & Finland & 0 & 0 & 0 & 0 & 0 & 0 & 0 \\
\hline & & Norway & $N R$ & NR & NR & NR & NR & NR & NR \\
\hline & & Sweden & NR & NR & NR & NR & NR & NR & NR \\
\hline \multirow[t]{5}{*}{ Diffuse } & 60406 & & & \multicolumn{6}{|c|}{ Chlorine-containing solvents - use } \\
\hline & & Denmark & 35161 & 32718 & 32069 & 29823 & 19051 & 245 & 187 \\
\hline & & Finland & 1350 & 1250 & 1094 & 1421 & 1407 & 1110 & 1317 \\
\hline & & Norway & NR & NR & NR & NR & NR & NR & NR \\
\hline & & Sweden & NR & NR & NR & NR & NR & NR & NR \\
\hline
\end{tabular}

*,unspecified total 
Data on production and uses in the Nordic countries are very limited and scattered. Activity data have been extracted from Statistics Denmark. For Finland, the data were taken from the Finnish IIR (SYKE, 2007). Data reported in the EUROSTAT PRODCOM database were either confidential or reported as zero. It has not been possible to derive reliable data from statistics Norway and Sweden. For Denmark data was extracted from Statistics Denmark, both on the production and use of chlorinated organic chemicals. Emission factors are given below.

HCB emission from the use of chlorinated chemicals is calculated by multiplying the amount of imported chlorinated chemicals by an emission factor of $2 \mathrm{mg} / \mathrm{t}$ (EEA, 2006).

Table 3.2 Emission factors for unintentional HCB emissions from production and use of organic chlorinated solvents.

\begin{tabular}{|c|c|c|c|c|}
\hline SNAP & & $E F[\mu g / t]$ & Reference & www \\
\hline & Chemical industry & & & \\
\hline & $\begin{array}{l}\text { Chlorinated solvent } \\
\text { production }\end{array}$ & 1000000 & Bailey,2001 & \\
\hline 40413 & tetrachloromethane & 10000000 & EEA,2005 & $\begin{array}{l}\text { http://reports.eea.europa.eu/EMEPCO } \\
\text { RINAIR4/en/sources_of_HCB.pdf }\end{array}$ \\
\hline \multirow[t]{2}{*}{40413} & trichloroethylene & 4000000 & EEA,2005 & $\begin{array}{l}\text { http://reports.eea.europa.eu/EMEPCO } \\
\text { RINAIR4/en/sources_of_HCB.pdf }\end{array}$ \\
\hline & & 1200000 & $\begin{array}{l}\text { UK NAEI, } \\
2004\end{array}$ & \\
\hline \multirow[t]{4}{*}{40413} & tetrachlorosthylene & 6000000 & EEA,2005 & $\begin{array}{l}\text { http://reports.eea.europa.eu/EMEPCO } \\
\text { RINAIR4/en/sources_of_HCB.pdf }\end{array}$ \\
\hline & & 2400000 & $\begin{array}{l}\text { UK NAEI, } \\
2004\end{array}$ & \\
\hline & 1,1,1-trichloroethane & $1000000-6000000$ & $\begin{array}{l}\text { Pacyna, } \\
2003\end{array}$ & \\
\hline & & 2400000 & $\begin{array}{l}\text { UK NAEI, } \\
2004\end{array}$ & \\
\hline 40413 & perchloroethane & $3000000-10000000$ & $\begin{array}{l}\text { Pacyna, } \\
2003\end{array}$ & \\
\hline 60406 & $\begin{array}{l}\text { Chlorine-containing } \\
\text { solvents - use }\end{array}$ & 2000 & EEA, 2005 & $\begin{array}{l}\text { http://reports.eea.europa.eu/EMEPCO } \\
\text { RINAIR4/en/sources_of_HCB.pdf }\end{array}$ \\
\hline 60307 & $\begin{array}{l}\text { PCB-containing paint } \\
\text { use (open application) }\end{array}$ & 80000000000 & $\begin{array}{l}\text { Corinair } \\
\text { guidebook }\end{array}$ & $\begin{array}{l}\text { http://reports.eea.europa.eu/EMEPCO } \\
\text { RINAIR4/en/sources_of_PCB.pdf }\end{array}$ \\
\hline
\end{tabular}


Table 3.3 HCB emission from the production and use of chemicals [g]

\begin{tabular}{|c|c|c|c|c|c|c|c|c|c|}
\hline $\begin{array}{l}\text { PRTR } \\
\text { activity }\end{array}$ & SNAP & Emission [g] & 1999 & 2000 & 2001 & 2002 & 2003 & 2004 & 2005 \\
\hline \multirow[t]{11}{*}{$4 a$} & 40413 & $\begin{array}{l}\text { Chlorinated solvent } \\
\text { production }\end{array}$ & & & & & & & \\
\hline & & Denmark & 63 & 9 & NR & 4068 & 804 & NR & NR \\
\hline & & Finland & 0 & 0 & 0 & 0 & 0 & 0 & 0 \\
\hline & & Norway & NR & NR & NR & NR & NR & NR & NR \\
\hline & & Sweden & NR & NR & NR & NR & NR & NR & NR \\
\hline & 60406 & $\begin{array}{l}\text { Chlorine-containing } \\
\text { solvents - use }\end{array}$ & & & & & & & \\
\hline & & Denmark & 70 & 65 & 64 & 60 & 38 & 0 & 0 \\
\hline & & Finland & 3 & 3 & 2 & 3 & 3 & 2 & NR \\
\hline & & Norway & NR & NR & NR & NR & NR & NR & NR \\
\hline & & Sweden & NR & NR & NR & NR & NR & NR & NR \\
\hline & & $\begin{array}{l}\text { Inorganic chemicals } \\
\text { production }\end{array}$ & & & & & & & \\
\hline \multirow[t]{5}{*}{$4 b$} & & Potassium sulphate & & & & & & & \\
\hline & & Denmark & NR & NR & NR & NR & NR & NR & NR \\
\hline & & Finland & NR & NR & 8190 & 2480 & 460 & 16700 & NR \\
\hline & & Norway & NR & NR & NR & NR & NR & NR & NR \\
\hline & & Sweden & NR & NR & NR & NR & NR & NR & NR \\
\hline
\end{tabular}

Table 3.4 Activity data and emission factors for use of pesticides including HCB impurities

\begin{tabular}{lc}
\hline Active ingredient & HCB impurity concentration $[\mathrm{mg} / \mathbf{k g}]$ \\
\hline Lindane & 1 \\
Dacthal & 40 \\
Pentachlorophenol & 500 \\
Atrazine & 1 \\
Simazine & 1 \\
Picloram & 8 \\
PCNB & 500 \\
Chlorothalonil & 10 \\
Endosulfan & 0.1 \\
Clopyralid & 2.5 \\
\hline
\end{tabular}

None of the above-listed active ingredients in pesticide formulation are allowed for use in Denmark. Sales statistics from Finland reports $873 \mathrm{~kg}$ of the active ingredient clopyralid was sold in 2006. In use, this diffuse source corresponds to $2 \mathrm{~g}$ HCB released in 2006. Compared to the air emissions from the use of organic chlorinated solvents, at least in Denmark (Table 3.3.), this amount seems of minor importance. 



\section{Annex 4. Activity data and emission factors related to waste and wastewater management}

Table 4.1 Activity data for waste incineration [tonnes]

\begin{tabular}{|c|c|c|c|c|c|c|c|c|}
\hline $\begin{array}{l}\text { PRTR } \\
\text { code }\end{array}$ & $\begin{array}{l}\text { SNAP } \\
\text { code }\end{array}$ & Activity [tonnes] & 2001 & 2002 & 2003 & 2004 & 2005 & Reference \\
\hline \multirow{22}{*}{\multicolumn{2}{|c|}{90202}} & \multicolumn{7}{|l|}{ Industrial waste } \\
\hline & & Denmark & NA & NA & NA & NA & NA & \\
\hline & & Finland & NA & NA & NA & 15400 & NA & 1 \\
\hline & & Finland & 5773700 & 5051650 & 4041600 & 7129470 & 6812528 & 2 \\
\hline & & Norway & NA & NA & NA & 544572 & 491320 & 3 \\
\hline & & Sweden & NA & 1115730 & 1264860 & 1243840 & 1637440 & 4 \\
\hline & & \multicolumn{7}{|c|}{ Hazardous waste (including paint production waste and chlorine-containing wastes } \\
\hline & & Denmark & NA & NA & NA & 90599 & 82381 & 5 \\
\hline & & Finland & NA & NA & NA & 80000 & NA & 1 \\
\hline & & Finland & 187200 & 195000 & 183500 & 271829 & 215286 & 2 \\
\hline & & Norway & 65000 & 63000 & 74400 & 66600 & 46000 & 6 \\
\hline & & Sweden & NA & NA & NA & NA & NA & \\
\hline & & \multicolumn{7}{|c|}{ Contaminated timber (wood) } \\
\hline & & Denmark & NA & NA & NA & NA & NA & \\
\hline & & Finland & NA & NA & NA & 100 & NA & 1 \\
\hline & & Norway & NA & NA & NA & NA & NA & \\
\hline & & Sweden & NA & NA & NA & NA & NA & \\
\hline & & \multicolumn{7}{|l|}{ Solid wastes } \\
\hline & & Denmark & NA & NA & NA & NA & NA & \\
\hline & & Finland & NA & NA & NA & 3900 & NA & 1 \\
\hline & & Norway & NA & NA & NA & NA & NA & \\
\hline & & Sweden & NA & NA & NA & NA & NA & \\
\hline \multirow{6}{*}{\multicolumn{2}{|c|}{90205}} & \multicolumn{7}{|c|}{ Sewage sludge from WWTP } \\
\hline & & Denmark & NA & NA & NA & 54000 & 43000 & 5 \\
\hline & & Finland & NA & NA & NA & 7300 & NA & 1 \\
\hline & & Finland & 1800 & 2000 & 2100 & 2500 & 0 & 2 \\
\hline & & Norway & NA & NA & NA & NA & NA & \\
\hline & & Sweden & NA & NA & NA & 411000 & NA & \\
\hline \multirow{5}{*}{\multicolumn{2}{|c|}{90207}} & \multicolumn{7}{|l|}{ Hospital waste } \\
\hline & & Denmark & NA & NA & NA & NA & NA & \\
\hline & & Finland & 207 & 104 & 94 & 94 & 94 & 2 \\
\hline & & Norway & 143.8 & 143.8 & 143.8 & 143.8 & 143.8 & \\
\hline & & Sweden & NA & NA & NA & NA & NA & \\
\hline & 90201 & \multicolumn{7}{|c|}{ Domestic or municipal waste } \\
\hline & & Denmark & NA & 1491000 & 1463000 & 1470000 & 1467000 & 5 \\
\hline & & Finland & NA & NA & NA & 48900 & NA & \\
\hline & & Finland & 229566 & 189431 & 222806 & 235924 & 226843 & 2 \\
\hline & & Norway & 445000 & 492000 & 544000 & 539000 & NA & \\
\hline & & Sweden & NA & 1675180 & 1867670 & 1944290 & 2181890 & 7 \\
\hline \multicolumn{9}{|c|}{ References: } \\
\hline \multicolumn{9}{|c|}{$\begin{array}{l}\text { 1: Finnish waste statistics; http://www.tilastokeskus.fi/til/jate/2004/jate_2004_2006-09-05_tau_001_sv.html?/til/jate/ 2004/ } \\
\text { jate_2004_2005-12-13 tau_001.html } \\
\text { 2: Finnish waste statistics and expert judgement } \\
\text { 3: Statistics Norway;http://www.ssb.no/emner/01/05/20/avfind/tab-2006-12-22-03.html } \\
\text { 4: Statistics Sweden;http://wwww.avfallsverige.se/m4n?oid=1444\&_locale=1 } \\
\text { 5: DEPA, 2006; http://www2.mst.dk/udgiv/publikationer/2006/87-7052-284-7/html/default.htm } \\
\text { 6: Norwwegian waste statistics and expert judgement } \\
\text { 7: Norwegian waste statistics and expert judgement; http://statbank.ssb.no/statistikkbanken/Default } \\
\text { FR.asp?PXSid=0\&nvl=true\&PLanguage=0\&tilside=selecttable/hovedtabellHjem.asp\&KortnavnWeb=avfkomm } \\
\text { 8: Henriksen, T.C. et al., 2006; http://www.dmu.dk/Pub/FR602.pdf }\end{array}$} \\
\hline
\end{tabular}




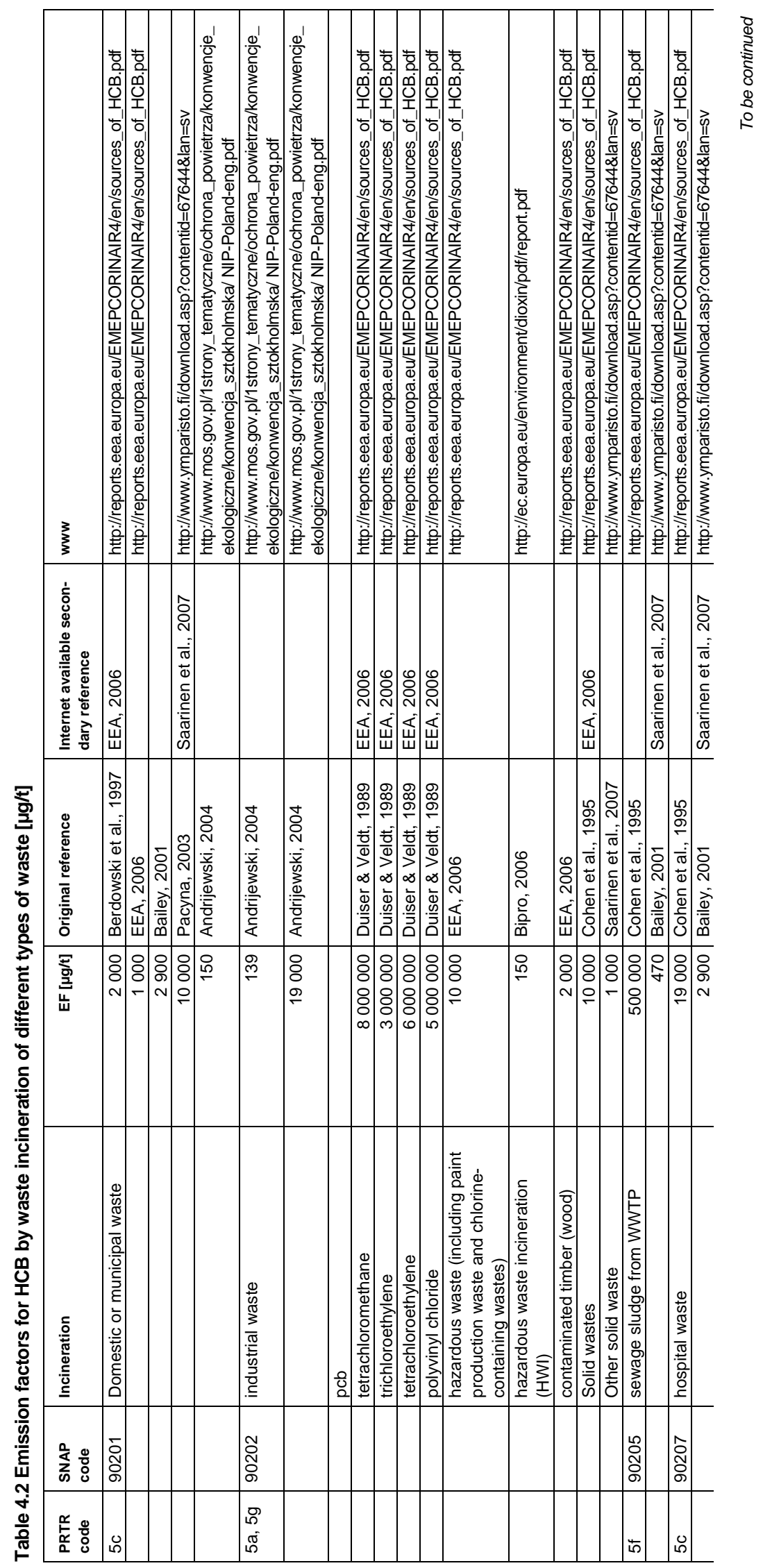




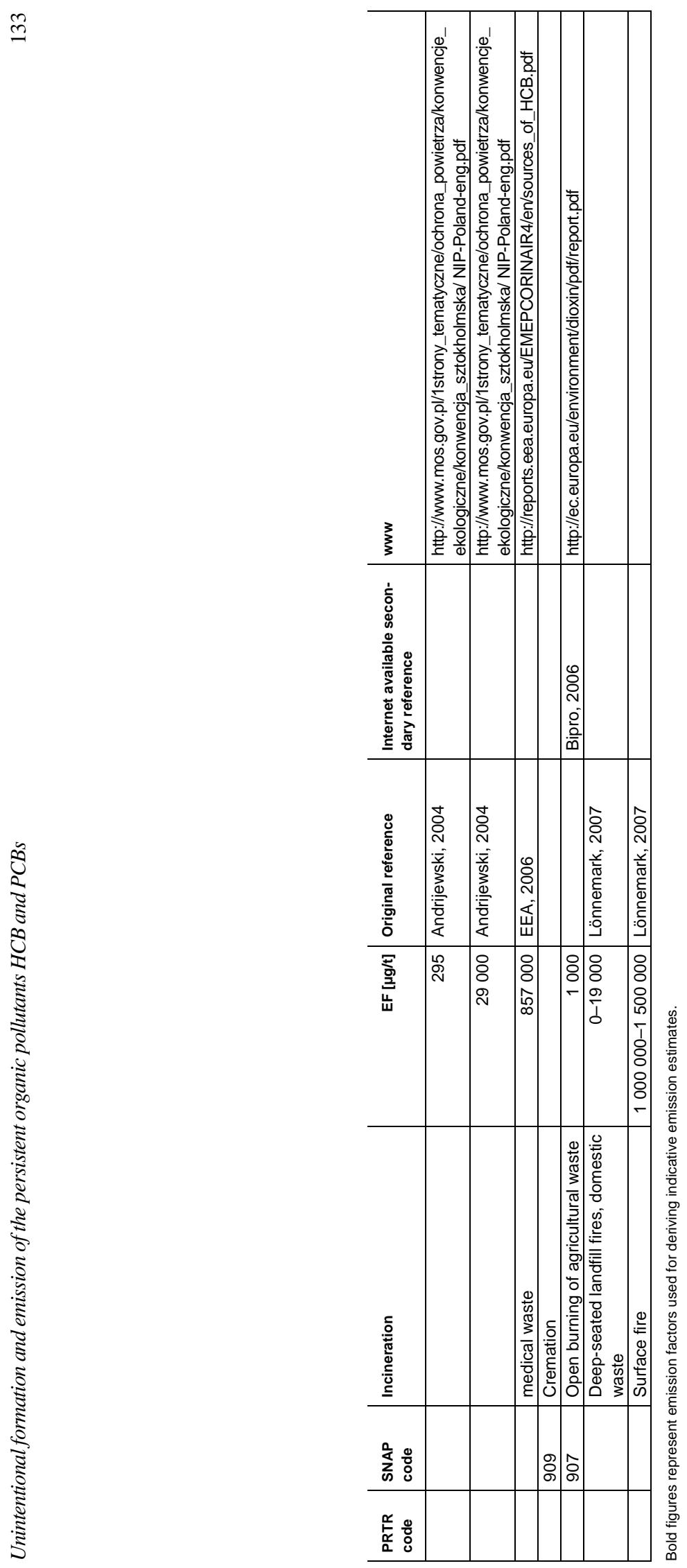


Table 4.3 Emission factors for PCB by waste incineration of different types of waste [ $\mu \mathrm{g} / \mathrm{t}]$

\begin{tabular}{|c|c|c|c|c|c|}
\hline $\begin{array}{l}\text { PRTR } \\
\text { code }\end{array}$ & $\begin{array}{l}\text { SNAP } \\
\text { code }\end{array}$ & Incineration & $\mathrm{EF}[\mu \mathrm{g} / \mathrm{t}]$ & Reference & www \\
\hline \multirow[t]{2}{*}{$5 c$} & 90201 & $\begin{array}{l}\text { domestic or municipal } \\
\text { waste }\end{array}$ & 820 & EEA, 2006 & $\begin{array}{l}\text { http://reports.eea.europa.eu/EME } \\
\text { PCORINAIR4/en/sources_of_- } \\
\text { PCB.pdf }\end{array}$ \\
\hline & & $\begin{array}{l}\text { municipal solid waste } \\
\text { (MSW) }\end{array}$ & 50000 & Bipro, 2006 & $\begin{array}{l}\text { http://ec.europa.eu/environment/di } \\
\text { oxin/pdf/report.pdf }\end{array}$ \\
\hline \multirow[t]{5}{*}{$5 a, 5 g$} & 90202 & industrial waste & 5000 & EEA, 2006 & $\begin{array}{l}\text { http://reports.eea.europa.eu/EME } \\
\text { PCORINAIR4/en/sources_of_ } \\
\text { PCB.pdf }\end{array}$ \\
\hline & & & 380 & $\begin{array}{l}\text { Andrijewski, } \\
2004\end{array}$ & $\begin{array}{l}\text { http://www.mos.gov.pl/1strony_te } \\
\text { matyczne/ochrona_powietrza/kon } \\
\text { wencje_ekologiczne/konwencja_s } \\
\text { ztokholmska/NIP-Poland-eng.pdf }\end{array}$ \\
\hline & & pcb & 10000000 & EEA, 2006 & $\begin{array}{l}\text { http://reports.eea.europa.eu/EME } \\
\text { PCORINAIR4/en/sources_of__ } \\
\text { PCB.pdf }\end{array}$ \\
\hline & & $\begin{array}{l}\text { hazardous waste (including } \\
\text { paint production waste and } \\
\text { chlorine-containing wastes) }\end{array}$ & & & \\
\hline & & $\begin{array}{l}\text { hazardous waste incinera- } \\
\text { tion (HWI) }\end{array}$ & 30 & Bipro, 2006 & $\begin{array}{l}\text { http://ec.europa.eu/environment/di } \\
\text { oxin/pdf/report.pdf }\end{array}$ \\
\hline $5 f$ & 90205 & sewage sludge from WWTP & 5000 & EEA, 2006 & $\begin{array}{l}\text { http://reports.eea.europa.eu/EME } \\
\text { PCORINAIR4/en/sources_of__ } \\
\text { PCB.pdf }\end{array}$ \\
\hline \multirow[t]{10}{*}{$5 c$} & 90207 & hospital waste & 20000 & EEA, 2006 & $\begin{array}{l}\text { http://reports.eea.europa.eu/EME } \\
\text { PCORINAIR4/en/sources_of_- } \\
\text { PCB.pdf }\end{array}$ \\
\hline & & & 390 & $\begin{array}{l}\text { Andrijewski, } \\
2004\end{array}$ & $\begin{array}{l}\text { http://www.mos.gov.pl/1strony_te } \\
\text { matyczne/ochrona_powietrza/kon } \\
\text { wencje_ekologiczne/konwencja_s } \\
\text { ztokholmska/NIP-Poland-eng.pdf }\end{array}$ \\
\hline & 909 & Cremation & 400 & Bipro, 2006 & $\begin{array}{l}\text { http://ec.europa.eu/environment/di } \\
\text { oxin/pdf/report.pdf }\end{array}$ \\
\hline & 907 & $\begin{array}{l}\text { Open burning of agricultural } \\
\text { waste }\end{array}$ & 35000 & Bipro, 2006 & $\begin{array}{l}\text { http://ec.europa.eu/environment/di } \\
\text { oxin/pdf/report.pdf }\end{array}$ \\
\hline & 90208 & waste oil incineration & & & \\
\hline & & $\begin{array}{l}\text { Barrel Burning of House- } \\
\text { hold Waste }\end{array}$ & 126000 & Lemieux, 2002 & \\
\hline & & $\begin{array}{l}\text { Deep-seated landfill fires, } \\
\text { domestic waste }\end{array}$ & & & \\
\hline & & WHO-PCB & $14000-140000$ & $\begin{array}{l}\text { Lönnermark et } \\
\text { al, } 2008\end{array}$ & \\
\hline & & PCB7 & $1800-16000$ & $\begin{array}{l}\text { Lönnermark et } \\
\text { al, } 2008\end{array}$ & \\
\hline & & Surface fire & $10000-40000$ & $\begin{array}{l}\text { Lönnemark, } \\
2007\end{array}$ & \\
\hline
\end{tabular}

Bold figures are selected emission factors used for deriving indicative emission estimates. 


\section{Annex 5. Chlorine in fuel types and waste fractions}

Table 5.1 Chlorine content in different fuel types and waste fractions (Zevenhoven and Kilpinen, 2001)

\begin{tabular}{ll}
\hline Chlorine in fossil fuels [mg/kg] & \\
\hline Coal, lignite & $50-2000$ \\
Peat & -500 \\
Estonian oil shale & -2000 \\
Petroleum coke, 'petcoke' & $\sim 300$ \\
Light fuel oil & - \\
Heavy fuel oil & $-1<20$ \\
OrimulsionTM & $\sim 700$ \\
Natural gas & - \\
\hline Chlor in biomass and waste streams [mg/kg] & \\
\hline Wood (firewood) & $0.08-0.13$ \\
Bark & $0.02-0.4$ \\
Straw & $0.1-1.5$ \\
Landfill gas & -50 ppmw CCl4 \\
Textile & $\sim 0.25$ \\
Newsprint paper & $\sim 0.11$ \\
Leather waste & $\sim 0.7-3$ \\
Sewage sludge & $0.03-1$ \\
Polyurethane foam (containing CFC11) & $\sim 8$ \\
PVC & -50 \\
Municipal solid waste (MSW) & $0.05-0.25$ \\
Refuse derived fuel (RDF) & $0.3-0.8$ \\
Packaging derived fuel (PDF) & $1-4$ \\
Car tyre scrap & $500-700$ \\
Auto shredder residue (ASR) & $0.5-2$ \\
Computer circuit boards (epoxy or phenolic resins) & $0.1-0.5$ \\
Computer monitor housings & 0.1 \\
Electric \& electronic equipment waste plastics & -3.5 \\
Mixed medical waste & $1-4$ \\
Black liquor solids & $0.05-0.2$ \\
\hline & \\
\hline & \\
\hline
\end{tabular}

Table 5.2 Chlorine in European waste fraction for combustion (Jacquinot et al. (2000).

\begin{tabular}{lrr}
\hline Waste fraction & Amount weight-\% & Chlor content weight-\% \\
\hline Household waste & 35 & 0.76 \\
Paper & 25 & 0.37 \\
Plastic & 8 & 2.36 \\
Glass & 9 & 0.01 \\
Metal & 4 & 0.03 \\
Total combustible (textiles, etc) & 19 & 1.0 \\
Total & 100 & 0.74
\end{tabular}





\section{Annex 6. Cremation and Uncontrolled/Accidental burning}

\section{Crematoria and animal carcass burning}

Currently cremation is not well addressed at country level (BiPRO, 2006). Still, information from the Swedish dioxin survey estimates a fluegas volume of $600 \mathrm{~m}^{3}$ per cremation (Bergquist et al., 2005). In Sweden 75 crematories are reported to be in operation; no information on technical details is available. Data on the number of cremations are limited, but in Sweden 57,000 cremations took place in 1990 and 61,237 in 1993.

The Danish numbers are given in Table 6.1 below. According to $\mathrm{Bi}-$ PRO (2006) the emission factor for PCB is $0.4 \mathrm{mg} / \mathrm{t}$

Table 6.1 Activity rates for cremations [cremation/yr]

\begin{tabular}{lrrrrrrrr}
\hline Cremations & $\mathbf{1 9 9 0}$ & $\mathbf{1 9 9 3}$ & $\mathbf{2 0 0 1}$ & $\mathbf{2 0 0 2}$ & $\mathbf{2 0 0 3}$ & $\mathbf{2 0 0 4}$ & $\mathbf{2 0 0 5}$ & Reference \\
\hline Denmark & 40991 & 43194 & 41707 & 42539 & 41997 & 41555 & 40758 & 1 \\
Finland & NR & NR & 13351 & 14354 & 14847 & 15508 & 16108 & 2 \\
Norway & NR & NR & NR & NR & NR & NR & NR & \\
Sweden & 57000 & 61237 & NR & NR & NR & NR & NR & 3 \\
\hline
\end{tabular}

References:

1: http://www.dkl.dk/statistik_1990_1999.aspx (in Danish)

2: www.shk.fi (in Finnish)

3: Naturvårdsverket, 2005

Assuming an average dead body weight of $70 \mathrm{~kg}$, the level of emission to air would be as illustrated in Table 6.2

Table 6.2 Potential PCB emission to air from cremations [mg/yr] ]

\begin{tabular}{lrrrrrrr}
\hline Cremations & $\mathbf{1 9 9 0}$ & $\mathbf{1 9 9 3}$ & $\mathbf{2 0 0 1}$ & $\mathbf{2 0 0 2}$ & $\mathbf{2 0 0 3}$ & $\mathbf{2 0 0 4}$ & $\mathbf{2 0 0 5}$ \\
\hline Denmark & 1148 & 1209 & 1168 & 1191 & 1176 & 1164 & 1141 \\
Finland & NR & NR & 374 & 402 & 416 & 434 & 451 \\
Norway & NR & NR & NR & NR & NR & NR & NR \\
Sweden & 1596 & 1715 & NR & NR & NR & NR & NR \\
\hline
\end{tabular}

Taking the number of reported cremations in Sweden into account, emissions from crematoria are judged to be below the E-PRTR reporting threshold of $0.1 \mathrm{~kg} / \mathrm{yr}$ pr crematorium. 


\section{Uncontrolled/Accidental burning}

According to an investigation of uncontrolled burning of garden and domestic waste (Hedman et al., 2005), a general emission factor for PCDF and PCB may be in the range of 4-72 ng/kg, with a median value of $20 \mathrm{ng} / \mathrm{kg}$ (WHO-TEQ); including values for the most common types of waste and excluding values from highly contaminated wastes which have to be added separately. The investigation suggests that backyard burning could generate similar amounts of emissions to combustion in municipal waste incinerators (MWI), even if the amounts of waste involved were 125-fold lower.

Open burning of waste is however forbidden in the Nordic countries (e.g. SFT, 2001) and Table 6.3 shows that burning of household waste in barrels as well as landfill fires are potential contributors to the total emission of PCBs and HCB. For comparison the national emission inventory from the UK showed that dioxin emissions from accidental fires contributed with $20 \%$ of the total dioxin emission. By comparing the emission factors (EF) for surface fires it is indicated that this may be a source of concern to unintentional emission of HCB and PCB.

Table 6.3 Emission factors for accidental fires $[\mu \mathrm{g} / \mathrm{kg}]$

\begin{tabular}{lr}
\hline Barrel Burning of Household Waste & EF \\
PCDD/F & 5.8 \\
PCB & 126 \\
Burning dumps and landfill fires & $15.5-590$ \\
PCB & \\
Deep-seated landfill fires, domestic waste & $14-140$ \\
PCB7 & $1.8-16$ \\
WHO-PCB & $0-19$ \\
HCB & \\
Surface fires, landfill & $10-40$ \\
PCB & $1000-1500$ \\
HCB & $0.05-0.9$ \\
dioxins & \\
\hline
\end{tabular}

Reference: Lemieux, 2002, Lönnemark, 2007 and 2008.

PCB7 and HCB were measured in the runoff water at levels below 0.02 $\mu \mathrm{g} / \mathrm{L}$ and for HCB below 0.5 to $1 \mu \mathrm{g} / \mathrm{L}$.

Table 6.4 Amount of waste burnt during spontaneous landfill fires [tonnes]

\begin{tabular}{lrrrrrr}
\hline Landfill fires & 2001 & 2002 & 2003 & 2004 & 2005 & Reference \\
\hline Denmark & NA & NA & NA & 15000 & 15000 & 1 \\
Finland & 324 & 37316 & 38084 & 28256 & 26874 & 2 \\
Norway & NA & NA & NA & NA & NA & \\
Sweden & NA & NA & NA & NA & NA \\
\hline
\end{tabular}

References:

1: Henriksen, T.C. et al., 2006

2: Finnish waste statistics and expert judgement 
Minimum reported emission factors for landfill surface fires have been used in Table 6.5 and Table 6.6 for the estimated number of fires.

Table 6.5 Estimated HCB emissions from landfill fires [kg/yr]

\begin{tabular}{lrrrrr}
\hline Year & $\mathbf{2 0 0 1}$ & $\mathbf{2 0 0 2}$ & $\mathbf{2 0 0 3}$ & $\mathbf{2 0 0 4}$ & $\mathbf{2 0 0 5}$ \\
\hline Denmark & NA & NA & NA & 15 & 15 \\
Finland & 42 & 37 & 38 & 28 & 27 \\
Norway & NA & NA & NA & NA & NA \\
Sweden & NA & NA & NA & NA & NA \\
\hline
\end{tabular}

Table 6.6 Estimated PCB emissions from landfill fires [g/yr]

\begin{tabular}{lccccc}
\hline Year & $\mathbf{2 0 0 1}$ & $\mathbf{2 0 0 2}$ & $\mathbf{2 0 0 3}$ & $\mathbf{2 0 0 4}$ & $\mathbf{2 0 0 5}$ \\
\hline Denmark & NA & NA & NA & 150 & 150 \\
Finland & 424 & 373 & 381 & 283 & 269 \\
Norway & NA & NA & NA & NA & NA \\
Sweden & NA & NA & NA & NA & NA \\
\hline
\end{tabular}

As observed in Table 6.5 and Table 6.6, landfill fires may represent important sources of unintentional emissions of HCB and PCBs. Still, as mentioned in Chapter 2, landfill as it is known to date is becoming a historical phenomenon; lower amounts of burnable waste are being deposited at landfill sites. The waste is deposited and sorted, and landfill sites are used as e.g. long-term mineralization reservoirs for the production of compost. 